\title{
Variations in Produced Water Chemistry and Relation to Regional Geology and Production in the Marcellus Shale, Northcentral West Virginia
}

Jonathan M. Brady

jmb019@gmail.com

Follow this and additional works at: https://researchrepository.wvu.edu/etd

Part of the Geochemistry Commons, Geology Commons, and the Oil, Gas, and Energy Commons

\section{Recommended Citation}

Brady, Jonathan M., "Variations in Produced Water Chemistry and Relation to Regional Geology and Production in the Marcellus Shale, Northcentral West Virginia" (2021). Graduate Theses, Dissertations, and Problem Reports. 8090.

https://researchrepository.wvu.edu/etd/8090

This Thesis is protected by copyright and/or related rights. It has been brought to you by the The Research Repository @ WVU with permission from the rights-holder(s). You are free to use this Thesis in any way that is permitted by the copyright and related rights legislation that applies to your use. For other uses you must obtain permission from the rights-holder(s) directly, unless additional rights are indicated by a Creative Commons license in the record and/ or on the work itself. This Thesis has been accepted for inclusion in WVU Graduate Theses, Dissertations, and Problem Reports collection by an authorized administrator of The Research Repository @ WVU. For more information, please contact researchrepository@mail.wvu.edu. 
Variations in Produced Water Chemistry and Relation to Regional Geology and Production in the Marcellus Shale, Northcentral West Virginia

Jonathan M. Brady

Follow this and additional works at: https://researchrepository.wvu.edu/etd

Part of the Geochemistry Commons, Geology Commons, and the Oil, Gas, and Energy Commons 


\title{
Variations in Produced Water Chemistry and Relation to Regional Geology and Production in the Marcellus Shale, Northcentral West Virginia
}

\author{
Jonathan M. Brady
}

\author{
Thesis submitted \\ to the Eberly College of Arts and Sciences \\ at West Virginia University \\ in partial fulfillment of the requirements for the degree of \\ Master of Science in \\ Geology
}

\author{
Timothy R. Carr, Ph.D., Chair \\ Joseph Donovan, Ph.D. \\ Shikha Sharma, Ph.D. \\ Paul Ziemkiewicz, Ph.D. \\ Department of Geology and Geography
}

Morgantown, West Virginia

2021

Keywords: Marcellus Shale, Geochemistry, West Virginia, Produced Water, Water Chemistry Copyright 2021 Jonathan M. Brady 


\title{
ABSTRACT \\ Variations in Produced Water Chemistry and Relation to Regional Geology and Production in the Marcellus Shale, Northcentral West Virginia
}

\author{
Jonathan M. Brady
}

An investigation of 74 Marcellus Shale wells across northcentral West Virginia indicates changes in produced water chemistry and quantity can be related to geologic conditions based on well logs and core data. These changes are determined by reviewing multiple produced water analyses for individual wells for periods up to ten years. Results show variations among the areas in this study. From west to east across central Harrison County to central Taylor County, then north into Monongalia County, gamma-ray logs show increasing intensity, especially in the middle and lower Marcellus. XRD mineralogy from core data shows increasing clay content from west to east with associated decreases in quartz. Produced water analyses show increases in barium concentrations from west to east, typically associated with increasing shale/clay minerals. Additionally, produced water samples show decreasing calcium and strontium concentrations moving west to east, suggesting that increased carbonate content, possibly as carbonate cement, is present in the western-most study areas. The geological differences across the area results in variations in produced water behaviors. Total dissolved solids (TDS) concentrations typically reach their maximum value during the second year of production. After this time, areas in Harrison County showed both increasing and decreasing TDS concentrations, while areas in Taylor and Monongalia showed almost exclusively decreasing concentrations over time. With TDS concentrations dropping below the maximum values, relative ratios of formation water vs. fracturing fluid can be determined in a given well as it ages. Normalized, cumulative gas production for these wells showed that the geologic differences observed in the produced water are reflected in different production rates across the study area. 


\section{TABLE OF CONTENTS}

Page

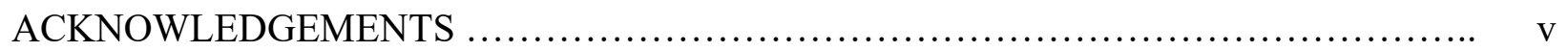

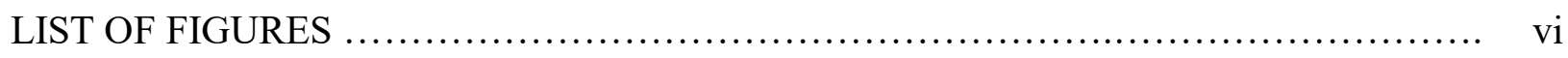

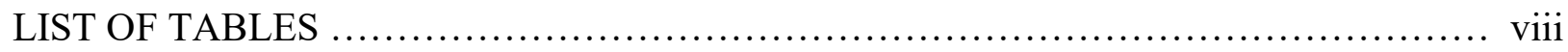

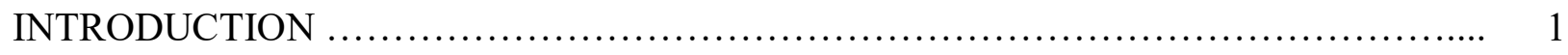

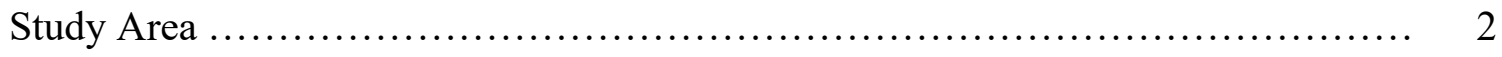

Methods ............................................................ 5

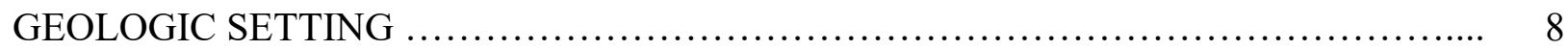

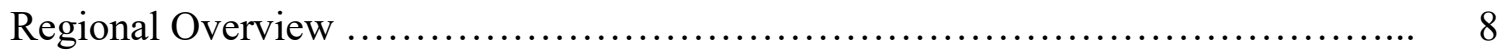

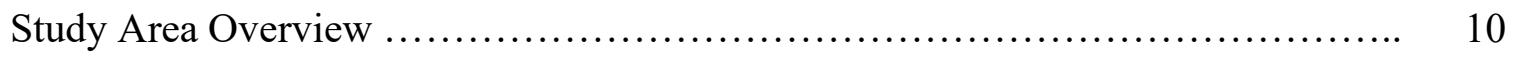

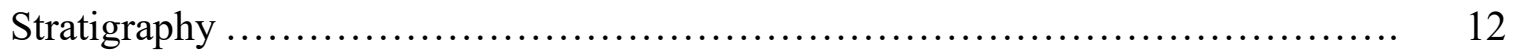

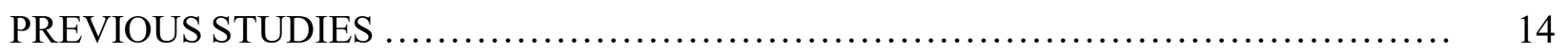

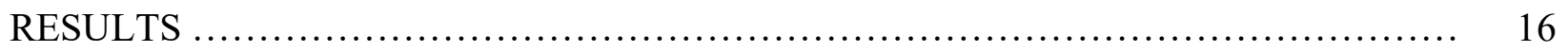

Well Log Analysis ................................................... 17

Estimating TOC using Pyrolysis and Well Logs ............................ 24

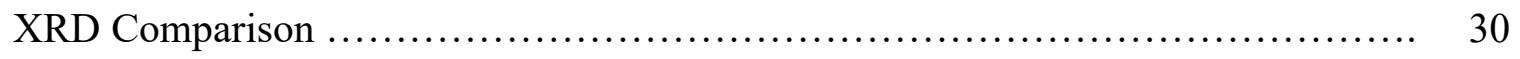

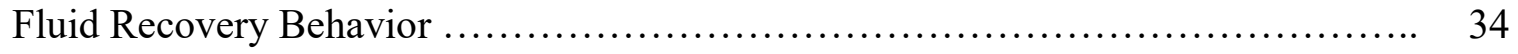

Water Sample Analysis - Source Water ................................ 41

Water Sample Analysis - Produced Water ................................ 43

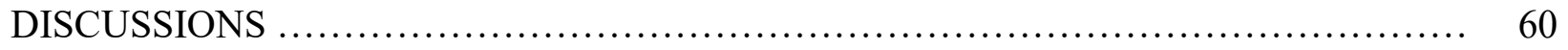

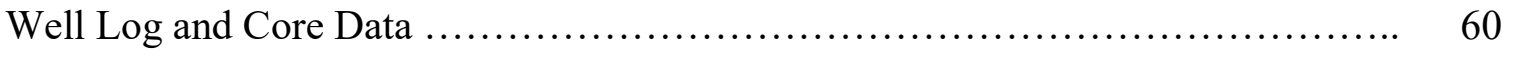

Carbonate Dissolution ................................................ 63

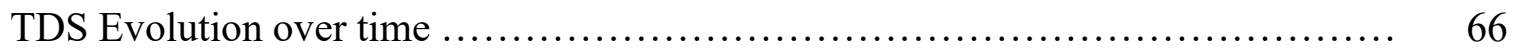

Influence on Natural Gas Production .................................... 67

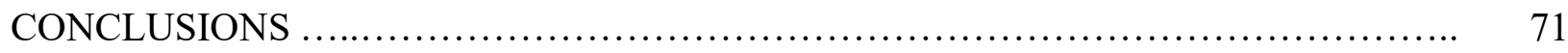

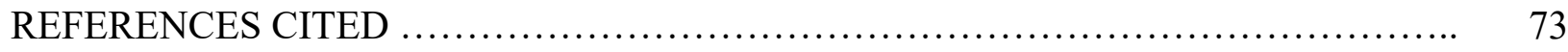

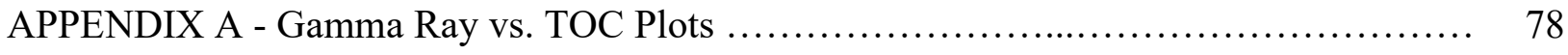


APPENDIX B - Daily Cumulative Percentage Fluid Recovery by Area ….............. 83

APPENDIX C - Ion Concentration Plots ................................................ 86

APPENDIX D - Produced Water Sample Results .................................... 90 


\section{ACKNOWLEDGMENTS}

First and foremost, I would like to thank my advisor, Dr. Timothy Carr for his willingness to take me on as a non-traditional graduate student and working with me through unique circumstances. Thank you for your guidance and patience as I got back in the groove of being a student. I would also like to thank my committee members Dr. Joseph Donovan and Dr. Shikha Sharma from the Department of Geology and Geography, and Dr. Paul Ziemkiewicz from the West Virginia Water Research Institute for their willingness to be a part of this project.

I would like to express my gratitude to Arsenal Resources for allowing me to use their historic produced water samples, without which this study would not have been possible. A big thank you to Brandon Wedde of Arsenal Resources for assisting and facilitating the collection of the last round of samples and John Landis of Northeast Natural Energy for facilitating sample collection from the MIP wells.

A special thank you goes to Gabriela Perhinschi and Todd Vincent of the NRCCE Lab for running my water samples and taking the time to explain results and answering my many, many questions. I would also like to recognize my fellow graduate students for reminding me how enjoyable it is to be on campus.

Most importantly, I would like to thank my wife, Beverly, for supporting my idea of going back to school for my master's degree and providing endless encouragement along the way. Finally, thanks to my administrative assistant Callie, the Labrador Retriever, whose tailwagging interruptions are always welcome. 


\section{LIST OF FIGURES}

FIGURE

1. Location of study area within Marcellus Shale Play .............................. 3

2. Location of five sub-areas within the larger study area $\ldots \ldots \ldots \ldots \ldots \ldots \ldots \ldots \ldots \ldots \ldots \ldots$

3. Diagram showing relationship between facies type and position in tectophases ......... 9

4. Cross-section showing maximum burial depth across study area $\ldots \ldots \ldots \ldots \ldots \ldots \ldots \ldots \ldots . \quad 10$

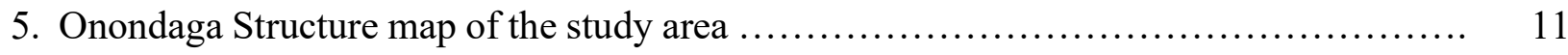

6. Log-sections showing general stratigraphy of the Marcellus Shale .................. 13

7. Location of core and well logs used in the study .............................. 18

8. Cross-section of well logs showing the Marcellus Shale across study area ............. 19

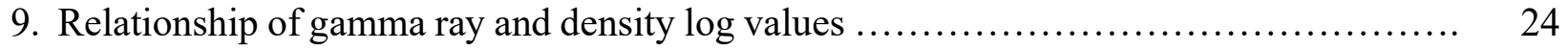

10. Relationship between gamma ray and log-calculated TOC for well logs ............. 26

11. Comparison of pyrolysis TOC and log-calculated TOC for cores $\ldots \ldots \ldots \ldots \ldots \ldots \ldots \ldots 27$

12. TOC relationship between Harrison Area 1 and Harrison Area 2 .................... 29

13. TOC relationship among Central Taylor, Northeast Taylor, and Monongalia areas ...... 30

14. Ternary diagrams showing quartz, clay and carbonate mineral content from core XRD .. 33

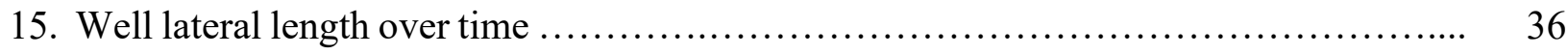

16. Volume of fluid pumped over time ......................................... 37

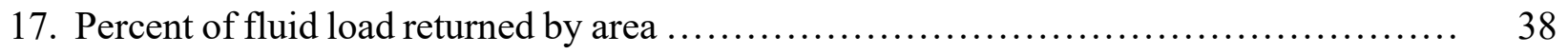

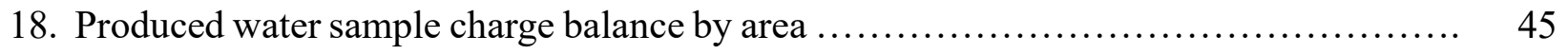

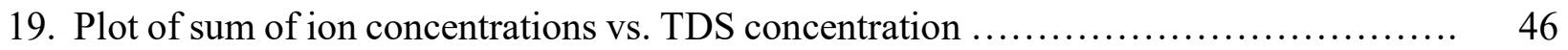

20. TDS Concentrations of produced water samples by area $\ldots \ldots \ldots \ldots \ldots \ldots \ldots \ldots \ldots \ldots \ldots \ldots$

21. Ternary plot of mean ionic concentrations of cations from produced water samples .... 49 
22. Mean proportional concentrations of ionic constituents of produced water samples ...... 51

23. Ionic proportions over time from well in Central Taylor .......................... 54

24. TDS concentrations over time for select Harrison Area 1 wells ....................... 55

25. TDS concentrations over time for select Harrison Area 2 wells ..................... 57

26. TDS concentrations over time for select Central Taylor Area wells .................. 57

27. TDS concentrations over time for select Northeast Taylor Area wells ................. 59

28. TDS concentrations over time for select Monongalia Area wells ..................... 59

29. $\mathrm{Ca} / \mathrm{Na}$ vs. $\mathrm{Cl}$ plot for all produced water samples across study area ................... 64

30. Ternary Plot comparing major cations in this study to a study in PA .................. 65

31. Cumulative gas production graphs for all wells by area $\ldots \ldots \ldots \ldots \ldots \ldots \ldots \ldots \ldots \ldots \ldots . \quad 70$ 


\section{LIST OF TABLES}

TABLE

PAGE

1. Summary of Marcellus Shale well $\log$ and TOC values $\ldots \ldots \ldots \ldots \ldots \ldots \ldots \ldots \ldots \ldots \ldots \ldots \ldots$

2. Summary of Marcellus Shale XRD and ELAN Log values ......................... 32

3. Summary of source water analyses ...................................... 42

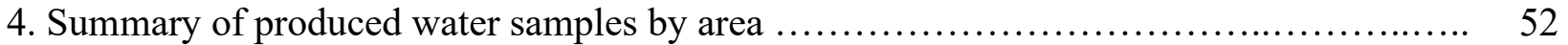




\section{INTRODUCTION}

Since its modern discovery as an unconventional shale resource in 2004, the Marcellus Shale has proven to be a world-class shale-gas reservoir (Zagorski et al., 2017). Dry gas production from the Marcellus has climbed from less than 0.5 billion cubic feet per day (bcfd) in January 2010 to over 24 bcfd in December 2020 plus a significant volume of natural gas liquids (NGL) (EIA, 2021). This represents just over $34 \%$ of total US dry shale gas production (EIA, 2021). The unprecedented growth in Marcellus natural gas production, coupled with the discovery and rapidly increasing production in other shale plays, has outpaced demand growth in the United States. As a result, multiple pipelines to Mexico and Canada have been developed, and liquid natural gas (LNG) facilities have been built on the Gulf Coast and Eastern Seaboard to compress and export gas worldwide. These LNG facilities led to the United States becoming a net exporter of natural gas in 2017 (EIA, 2019). This rapid rise in natural gas production has created an associated rise in flowback and produced water that requires treatment and disposal. Flowback water is generally considered to be the fluid returned immediately after hydraulic fracturing until the final production equipment is installed. Produced water is fluid produced after a well is placed into regular production.

Studies have examined both flowback and produced waters to illustrate how water chemistry changes among wells in different regions and over their production history. In the Marcellus, most studies have focused on the early changes and trends of flowback and produced water chemistry from 0-3 years after the start of flowback. These studies have focused primarily on wells in Pennsylvania and northern West Virginia (e.g., Blauch et al., 2009, Haluszczak et al., 2013, Rowan et al., 2015, Phan et al., 2020). Results from this early period are subsequently 
extrapolated over the lifetime of the well. This study will extend this timeframe by looking at produced water chemistry for up to 10 years after initial flowback across Harrison, Taylor, and Monongalia counties in northcentral West Virginia (WV). The primary focus is on both spatial and temporal variations of major ion chemistry such as $\mathrm{Ba}, \mathrm{Ca}, \mathrm{Na}, \mathrm{Sr}$, and $\mathrm{Cl}$ as well as total dissolved solids (TDS) in the produced water of five Marcellus producing areas across northcentral WV. This study will concentrate on changes in produced water characteristics over time as the wells in these areas have been sampled multiple times up to ten years after they went into production. The study will also demonstrate how produced water chemistry changes across the area and its relationship to changes in geology. Monitoring produced water chemistry during the entire lifespan of a producing well may contribute to a better understanding of regional geology and production trends in the Appalachian basin.

\section{Study Area}

This study focuses on an area in northcentral West Virginia that runs from central Harrison County northeast through Taylor County, then north into Monongalia County (Figure 1). The study area has a combined 74 wells in five different areas of Marcellus production (Figure 2). Two of these areas are adjacent to each other in central Harrison County. Harrison Area 1 contains 20 wells drilled between 2010 and 2017. Three additional wells were drilled in 2019 but were not included in this study. Harrison Area 2 lies immediately south of Harrison Area 1 and contains 18 wells drilled from 2012 to 2017 . These areas were separated for ease of data display, but also because there is approximately 4.5 miles $(7.2 \mathrm{~km})$ between the southernmost wells in both areas, which provides a more localized area to compare data. Both core and open-hole 


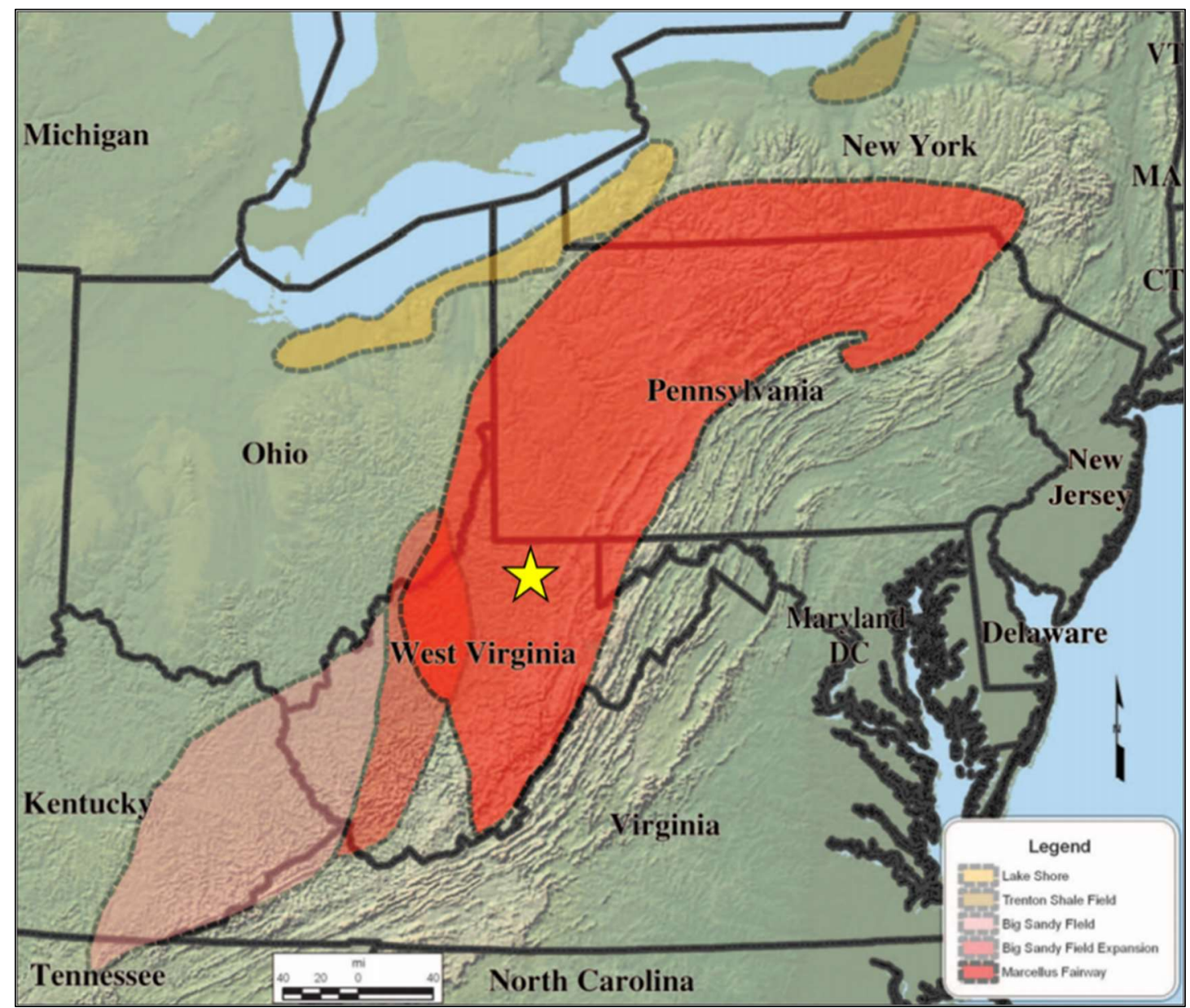

Figure 1 - Location of study area within the Marcellus Shale Play (Modified from Zagorski et al., 2012)

geophysical well logs were taken from one well in Harrison Area 1, but only well logs were available for Harrison Area 2. The third area is located near the central part of Taylor County and will be referred to as the Central Taylor Area. This area is $\sim 11$ miles $(17.7 \mathrm{~km})$ east-northeast of Harrison Area 1 and contains 18 wells that were drilled between 2010 and early 2018. Both core and well logs are available for one well in this area. The fourth area is $\sim 10$ miles $(16.1 \mathrm{~km})$ northeast of the Central Taylor Area, located in northeastern Taylor County, and will be referred to as the Northeast Taylor Area. It contains 14 wells that were drilled between 2013 to the end of 2017. Eleven of these 14 wells were drilled from southeast to northwest with a bottom-hole location in easternmost Marion County. There is no core data available for this area, however, 
open-hole logs were obtained for a pilot-hole well and can be used for well log comparisons. The fifth area lies in central Monongalia County and is $\sim 9$ miles $(14.5 \mathrm{~km})$ north of the Northeast Taylor Area. The Monongalia Area contains four wells, two of which were drilled as part of the Marcellus Shale Energy and Environmental Laboratory (MSEEL) study. The four wells in this area were drilled from 2011 to 2015. As part of the MSEEL study, both core and open-hole logs were obtained in this area. While the MSEEL study has provided a tremendous opportunity to study the Monongalia County area, Harrison and Taylor counties have been relatively understudied in comparison.

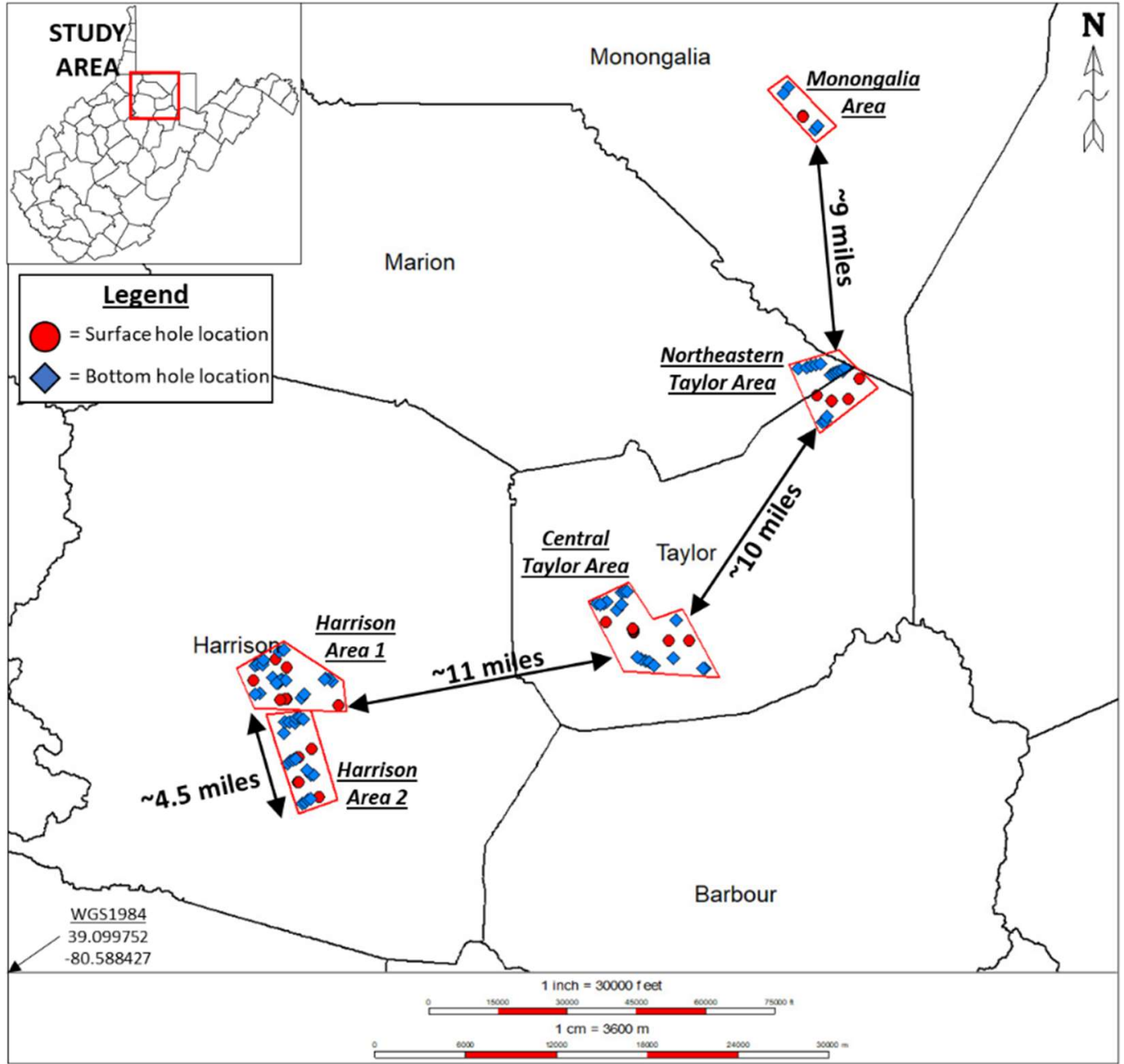

Figure 2 - Location of five sub-areas that contain wells in this study and the distance between each area. Red circles indicate surface locations. Blue diamonds indicate bottomhole locations. All wells have horizontal paths trending northwest - southeast. 


\section{Methods}

\section{Core Data}

Full-wellbore cores were taken on multiple wells among the five areas in this study. One fullwellbore core is located in each of Harrison Area 1, the Central Taylor Area, and the Monongalia Area. Of the many tests run on samples from these cores, X-ray diffraction (XRD) and pyrolysis results are used in this study. XRD determines the mineralogy of a sample and pyrolysis determines the total organic content (TOC). For the Harrison Area 1 and Central Taylor cores, Core Laboratories (Core Lab) performed the XRD analysis and contracted out the pyrolysis analysis to Weatherford Laboratories. For the Monongalia core, XRD work was performed and detailed by Hupp (2017) and Hupp and Donovan (2018). Pyrolysis and additional XRD analysis were performed by Paronish (2018). These analyses are used to compare mineralogy and TOC among the five areas, then combined with wells logs and produced water analyses to analyze geologic changes across the entire study area.

\section{$\underline{\text { Well Logs }}$}

Five gamma ray and density well logs are available for analysis, one for each area in this study. Schlumberger performed the logging for the wells in Harrison Area 1, Central Taylor, Northeast Taylor, and Monongalia. Weatherford logged the well in Harrison Area 2. For this study, normalized gamma-ray logs are the primary curve used for picking formation tops and comparing geology among the five areas. Density logs are used to calculate estimated TOC weight percent using the Schmoker equation applied to pyrolysis data (Schmoker, 1979, 1981, 1993). Elemental Analysis (ELAN) logs quantify minerals such as clay, quartz, and carbonate every 0.5 feet ( 0.15 meters) through the Marcellus and are compared to the core-derived XRD 
data to determine how the mineralogy varies across the study area. ELAN logs were run in the same wells that were cored and are available for one well each in Harrison Area 1, Central Taylor, and Monongalia areas. Any differences in geology evident from the well log comparison are tied back to mineralogy and TOC data derived from the core and compared to the produced water analyses.

\section{Source Water Locations and Analysis}

The source water for hydraulic fracturing operations for the wells in this study was taken from multiple sources. Samples were taken from each source and analyzed for major ions. Wells in Harrison areas 1 and 2 used water primarily from the West Fork River, near Clarksburg, WV. The Central Taylor Area used water sourced from both the West Fork River and the Tygart River near Grafton, WV. Wells in the Northeast Taylor Area were fractured with water primarily from the Tygart River. In addition to these primary water sources, produced water from the operator's (Arsenal Resources) existing wells was combined with water from these other sources.

Discussion with the operator's completion manager indicated that produced water only accounted for 3\%-5\% of water used during hydraulic fracturing (Arsenal Resources, personal communication). Water samples were also obtained and analyzed after this mixing occurred. Source water samples from the West Fork River, Tygart River, and produced water mixture were analyzed by the Chemplex Solvey Company for TDS, the cations $\mathrm{Na}, \mathrm{Ca}, \mathrm{Mg}, \mathrm{Ba}, \mathrm{Sr}, \mathrm{K}, \mathrm{Fe}$ and the anions $\mathrm{Cl}, \mathrm{SO}_{4}, \mathrm{HCO}_{3}, \mathrm{CO}_{3}$. Additional water analysis was performed for $\mathrm{Ca}, \mathrm{Mg}, \mathrm{Ba}, \mathrm{Cl}$, $\mathrm{SO}_{4}$, and $\mathrm{HCO}_{3}$ once the necessary chemical additives for hydraulic fracturing were combined into the fresh source water. Source water analyses were not available prior to those taken by 
Arsenal Resources in January 2019, but it is assumed that water chemistry for the West Fork River and Tygart River did not change significantly from 2010 to 2019.

The wells in the Monongalia Area were drilled by a different operator, Northeast Natural Resources (NNE), and used the Monongahela River as the primary water source for hydraulic fracturing operations. Water samples of the river were taken for chemical analyses prior to the onset of hydraulic fracturing operations. These samples were analyzed by Pace Analytical for the same major and minor ion suites analyzed in the Harrison and Taylor areas.

\section{Produced Water Collection and Analysis}

202 produced water samples from 74 wells across the five sub-areas were analyzed for this study. The samples were collected at different times over the lifespan of each well ranging from a few months to 10 years after hydraulic fracturing. Produced water samples were taken at either the gas/water separator, or if sufficient water was not available in that separator, from the sand separator. Laboratory analyses for samples taken prior to 2020 were obtained courtesy of Arsenal Resources and the MSEEL study. Samples obtained from the MSEEL study for the Monongalia Area wells were analyzed by Pace Analytical for major and minor ions including those used in

this study: $\mathrm{Ba}, \mathrm{Ca}, \mathrm{Mg}, \mathrm{Fe}, \mathrm{K}, \mathrm{Na}, \mathrm{Sr}$, and $\mathrm{Cl}$. TDS were calculated using all ions measured in the sample. Sample results for wells in Harrison and Taylor counties were obtained from Arsenal Resources including analyses for samples taken as early as 2013. Arsenal Resources used multiple laboratories for sample analysis over this time period including Weatherford Laboratories, Terra Oilfield Services, Baker Hughes, and Nalco Champion (now ChampionX). These analyses included all the ions examined in this study $(\mathrm{Ba}, \mathrm{Ca}, \mathrm{Mg}, \mathrm{Fe}, \mathrm{K}, \mathrm{Na}, \mathrm{Sr}, \mathrm{Cl}$ and 
TDS) although some samples were not tested for K, a minor ion in these samples. The methodology used by these laboratories to determine TDS in unknown. The most recent round of sampling for 69 of the 74 wells in the study was performed in 2020 and ran by the National Research Center for Coal and Energy (NRCCE) Laboratory at West Virginia University and were tested for all of the ions being considered for this study. The NRCCE lab used the gravimetric method to determine TDS in all the samples they tested.

\section{GEOLOGIC SETTING}

\section{Regional Overview}

The Appalachian basin underwent multiple orogenic events during the Paleozoic Era: the Taconic, Acadian, and Alleghenian orogenies. It was during the Middle Devonian Acadian orogeny that the Marcellus Shale was deposited in a subsiding, foreland basin (Ettensohn, 1985). Ettensohn (1985) suggested that the Acadian orogeny can be broken into four separate tectophases, each characterized by a pattern of four stages that can be discerned in the sedimentary record (Figure 3). The first stage marks the inception of tectonism with the formation of a foreland basin caused by rapid subsidence combined with transgressive seas that result in the deposition of basinal black shale (i.e. the Marcellus). The second stage involves a collision of promontory areas combined with sea-level regression and an influx of clastic sediment above the black shale. This stage may also contain multiple, minor transgressiveregressive sequences that can cause minor carbonate or black shale units in an overall gray shale and siltstone unit such as the Mahantango Shale (Ettensohn, 1985). The third stage includes continuous collision with regional uplift that results in regional unconformities that may have reached into the subsided basin depending on location such as the unconformity at the top of the 
Hamilton Group in New York. The fourth stage is marked by a period of tectonic quiescence and by the deposition of carbonates over the clastic sequence in a slowly transgressing sea; examples of these carbonates include the Onondaga and Tully limestone units. It is during stage 1 of the second Acadian tectophase that the Marcellus Shale was deposited.

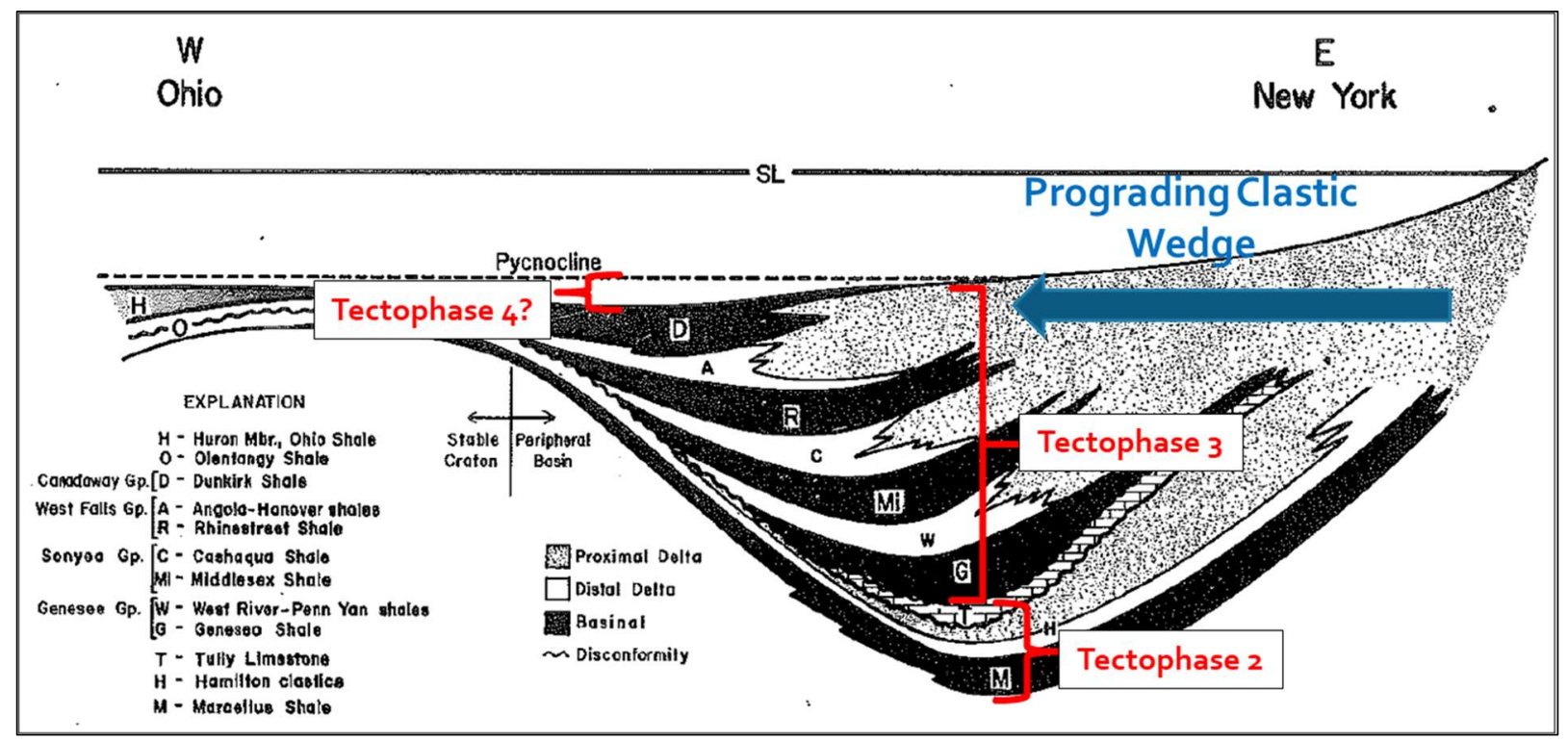

Figure 3 - Diagram showing relationships between facies type and position in tectophases. The explanation illustrates which Middle and Upper Devonian formations fall within each proposed tectophase. The Marcellus Shale is located at the beginning of tectophase 2. Tectophase 1 is not shown in this figure (Modified from Ettensohn, 1985).

After deposition and subsequent burial, the Marcellus Shale was buried even deeper during the Alleghenian orogeny. The Alleghenian orogeny began in the Carboniferous and ended in the late Permian resulting in the deepening of the Appalachian foreland basin (Wilkins et al., 2014).

Fluid inclusion studies performed using hydrocarbon and aqueous inclusions found in calcite, barite, quartz, and dolomite-bearing veins have been used to calculate a maximum burial depth of around $25,000 \mathrm{ft}(7.6 \mathrm{~km})$ for the Marcellus during this orogenic event near the Allegheny Structural Front in Pennsylvania.

Other fluid inclusion work by Evans (1995) and Rowan (2006) on a deep well core in Marion 
County, WV, calculated maximum burial depth of around 17,500 ft (5.3 km). Evans (1995) refers to this area as the Alleghenian Plateau Province (Figure 4). The temperatures associated with the maximum burial depth at both the Allegheny Structural Front $\left(200^{\circ} \mathrm{C}+\right)$ (Wilkins, 2014) and Allegheny Plateau Province $\left(160^{\circ} \mathrm{C}\right)($ Evans, 1995$)$ places the Marcellus Shale's thermal maturity strictly in the dry gas window in the study area. Since the end of the Alleghenian orogeny in the late Permian, steady exhumation of the Marcellus has been occurring throughout the basin; current depths are $\sim 6,500 \mathrm{ft}(2 \mathrm{~km})$ in the Allegheny Plateau Province (Evans, 1995) and $\sim 8,000 \mathrm{ft}$ (2.4 km) near the Allegheny Structural Front (Wilkins, 2014).

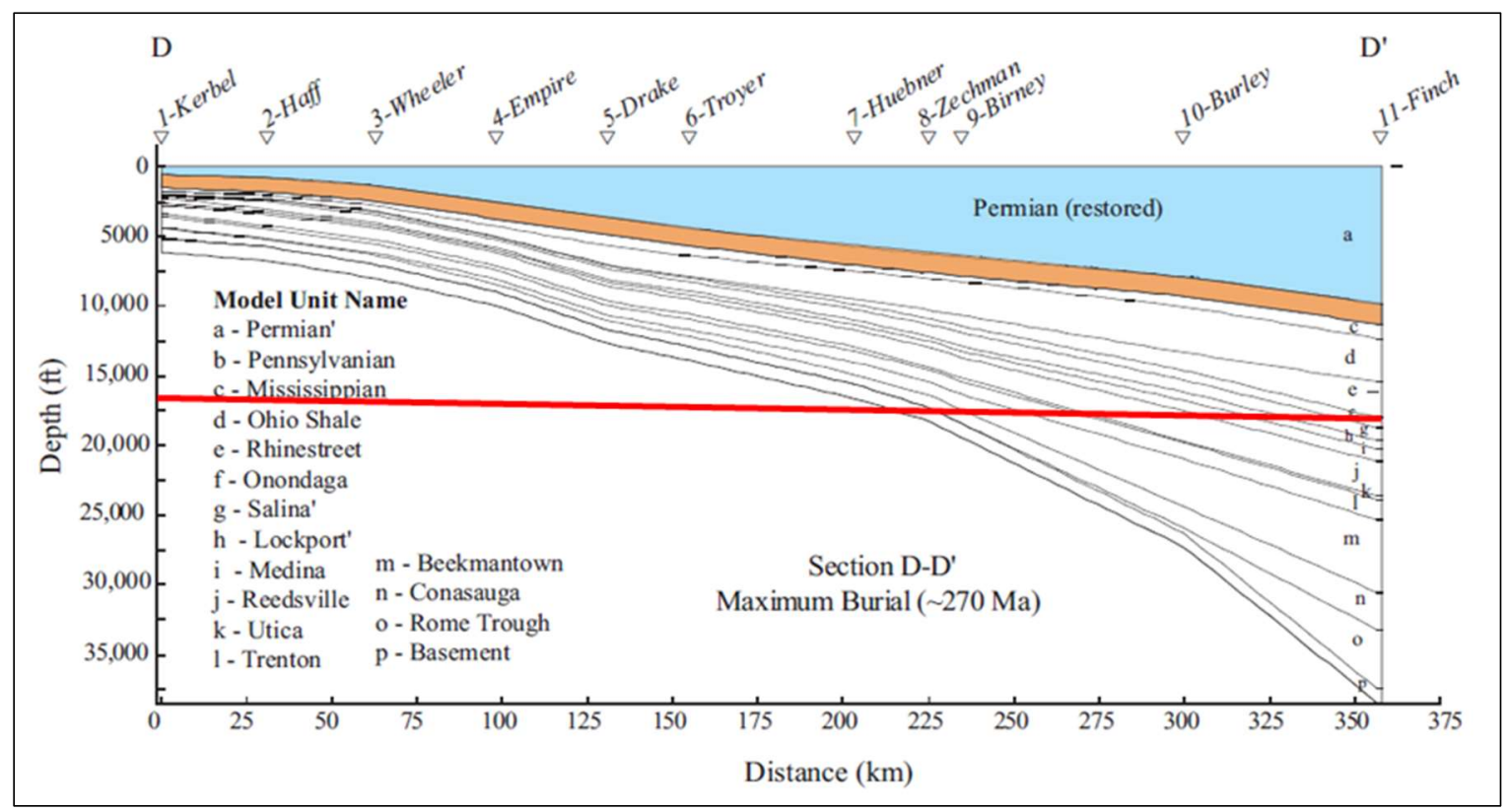

Figure 4 - Cross-Section showing maximum burial depth from Northwest Ohio (D) to Northern West Virginia $\left(D^{\prime}\right)$. 11-Finch is a deep well in Marion County, $W V$, near the study area. The approximate Onondaga Top in the study area is represented by the red line. (Modified from Rowan, 2006).

\section{Study Area Overview}

Focusing on the three-county study area, the Marcellus generally increases in depth from west to east with the deepest area located in southern Taylor County where the top of the Onondaga Limestone approaches $-6,800$ feet subsea (Figure 5). The section shallows to the east of the 
southern Taylor area over the Laurel Ridge anticline, which aligns with the Allegheny Structural Front. Across the study area, the section contains low-angle, undulating folds as evident from the Onondaga structure map (Figure 5). These data suggest that the well areas may be ranked with respect to depth as follows, from shallowest to deepest: Harrison Area 1, Northeast Taylor, Harrison Area 2, Monongalia, and Central Taylor. The Northeast Taylor Area is an interesting

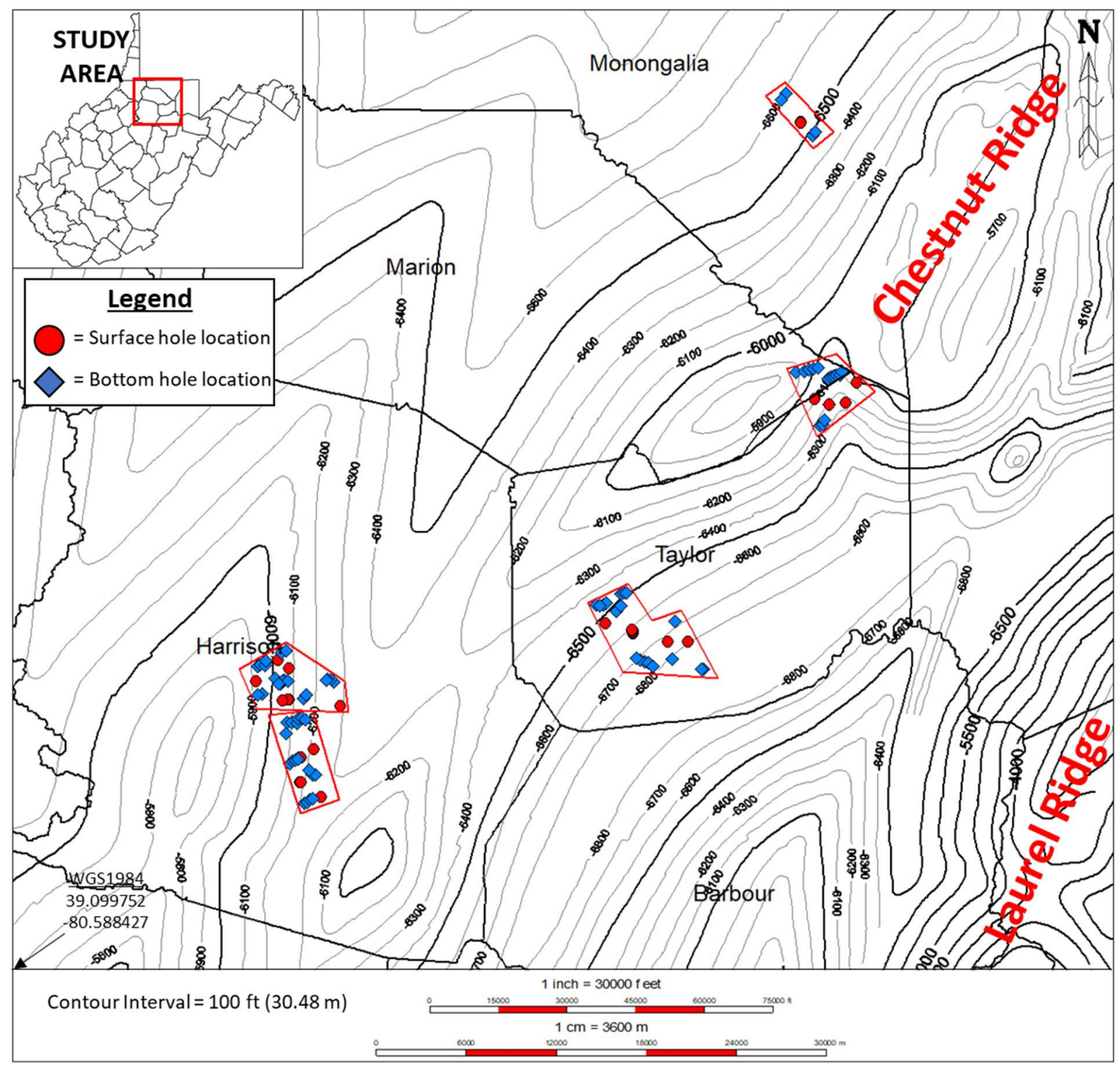

Figure 5-Structure contours of the top of the Onondaga Limestone across the study area. The structure shows low-angle folds across the area and the flank of the Allegheny Structural Front (Laurel Ridge) in the east. The plunging nose of the Chestnut Ridge Anticline is also seen in the northeast. (data source: West Virginia Geological and Economic Survey). 
case as it lies east of the Monongalia and Central Taylor areas but is shallower than both, breaking the general west to east deepening trend. This shallowing is the result of the southwestern nose of the Chestnut Ridge Anticline, which dies out in the southern Marion County, northern Taylor County area (Figure 5). The Monongalia Area is west of the anticline and sees little effect. The Central Taylor area is east of the anticline and slightly south of the anticline's plunging nose, again resulting in little effect. Other than the effects of the plunging nose of the Chestnut Ridge Anticline, the study area is structurally quiet.

\section{Stratigraphy}

The middle Devonian Marcellus Shale is part of the Hamilton Group that stretches from the base of the middle Devonian Tully Limestone to the top of the lower Devonian Onondaga Limestone (Zagorski, 2017). The Hamilton Group is broken down into the Mahantango Shale and the Marcellus Shale. The Marcellus is then divided into two main organic-rich shale members. The lower member is the Union Springs, which lies above the Onondaga Limestone. In northern West Virginia, this is marked by a transition zone going from limestone to highly organic shale. To the west, an unconformity marks this transition (Ettensohn, 1985 \& Zagorski, 2017). The Cherry Valley Limestone lies on top of the Union Springs and separates it from the Oatka Creek Member, which is the second organic-rich shale member (Figure 6A) (Lash and Engelder, 2011 and Zagorski, 2017). In some areas, the Oatka Creek is broken down into "Upper Marcellus A" and "Upper Marcellus B" with the "Lower Marcellus" being equivalent to the Union Springs Member (Boswell and Pool, 2018). Above the Oatka Creek Member is the Mahantango Shale, an organic-lean, gray shale bounded on top by the Tully Limestone (Ettensohn, 1985). 


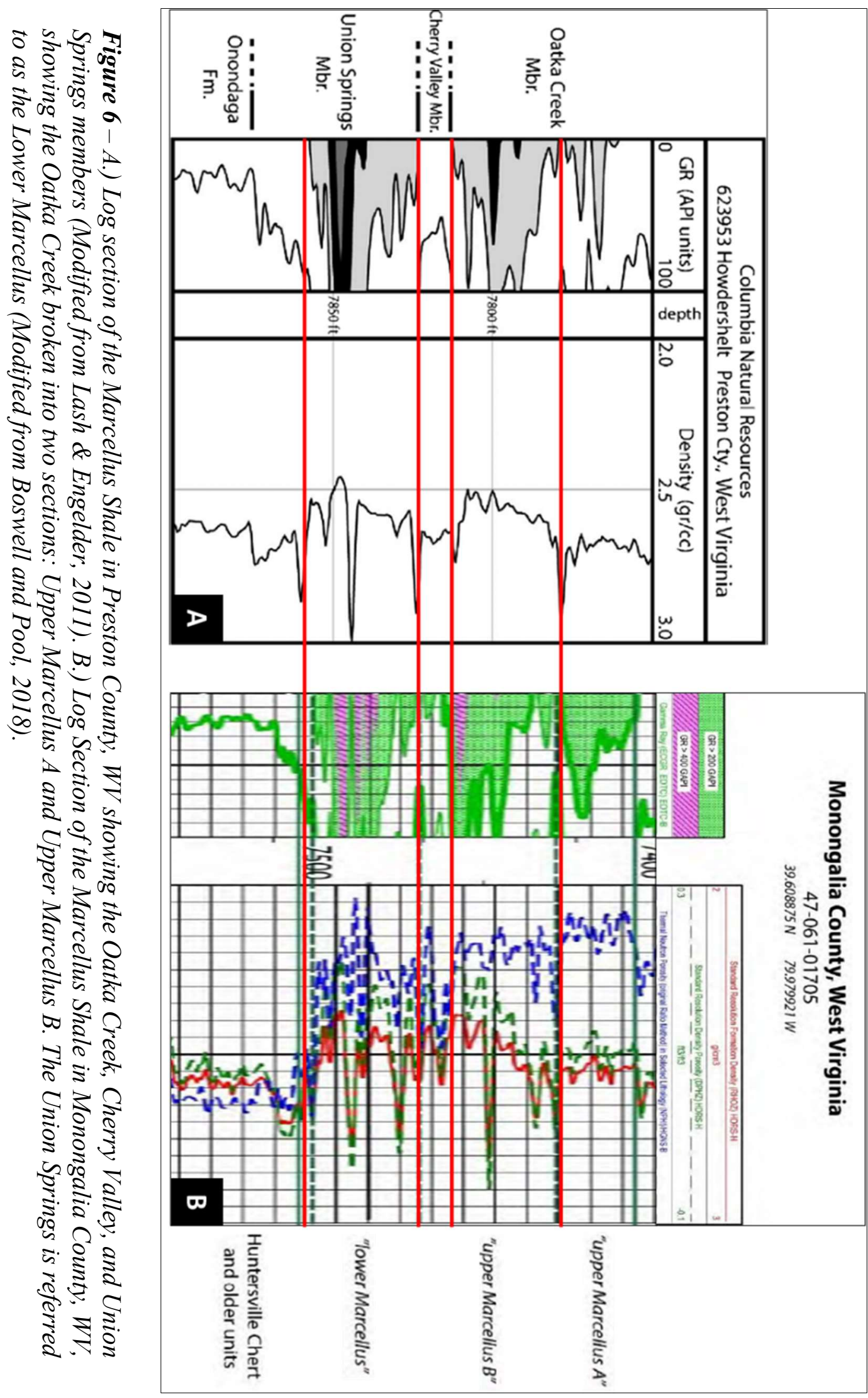


This study focuses primarily on the Marcellus Shale section of the Hamilton Group. Across the study area, the Marcellus shale is most similar to the Oatka Creek Member that contains two distinct high gamma-ray peaks (Figure 6B). The nomenclature for the rest of the study refers to the top Oatka Creek peak as the upper Marcellus and the bottom Oatka Creek peak as the middle Marcellus, while the Union Springs is referred to as the lower Marcellus. All of the wells in this study have horizontal wellbores that targeted the middle or lower Marcellus.

\section{PREVIOUS STUDIES}

Numerous studies have been performed looking at flowback and produced water characteristics and trends in the Marcellus Shale. Many of these examined samples from northeastern and southwestern Pennsylvania, with a few extending south into northern West Virginia, particularly the MSEEL study area. Few studies incorporate data from Harrison and Taylor counties.

Temporally, most studies focus on the first few months to years of a well's flowback/production history, with a couple extending as much as five years.

One of the first studies that looked at post-fracturing flowback and produced water documented increasing salt concentrations in the flowback water of multiple Marcellus Shale wells (Blauch et al., 2009). The study looked at samples collected over an 18-month period in southwestern and northeastern Pennsylvania and one well in northern West Virginia. Increasing levels of $\mathrm{Na}, \mathrm{Ca}$, $\mathrm{Ba}, \mathrm{Sr}$, and $\mathrm{Cl}$ ions among other ionic constituents could not be immediately explained.

Ultimately, Blauch et al. (2009) developed four hypotheses for the origin of the salinity: 1.)

primary dissolution of autochthonous salt, 2.) primary dissolution of allochthonous salt, 3.)

encroachment of basinal brine, 4.) mobilization of hypersaline connate fluid. This early study 
was the model for subsequent studies looking at variations in flowback and produced water chemistry over time and space.

Following Blauch et al., (2009), multiple studies were performed primarily looking at $\mathrm{Na}, \mathrm{Ca}, \mathrm{Cl}$, and $\mathrm{Br}$ trends in samples from Pennsylvania over the first few months to two years of production. These studies concluded that the high concentrations of salts observed in flowback and produced waters were the result of highly saline brine evaporated from paleo-seawater mixed with the formation fluid and injected fluid, not from halite dissolution (Dressel and Rose, 2010, Barbot et al., 2013, Haluszczak et al., 2013, Engle and Rowan, 2014, Balashov, et al., 2015, Rowan et al., 2015). Strontium also increased in concentration with time after hydraulic fracturing. Strontium isotope studies from Marcellus water samples over the first few years of production also indicated a paleo-seawater source for strontium, but with additional ion exchange with formation minerals (Chapman et al., 2012, Capo et al., 2014). Other studies focused on fluid-rock interactions determined that carbonate minerals were likely the primary source of strontium, with lesser contribution from paleo-seawater (Phan et al., 2018, Pilewski et al., 2019, Phan et al., 2020). A more recent study of Marcellus Shale produced water compared to produced waters from other hydrocarbon reservoirs examined controls on the aqueous geochemistry such as calcite dissolution and dolomitization (Sharma et al., 2021).

Multiple studies addressed the quantity of returned fluid versus the amount pumped, and how much of the returned fluid is hydraulic fracturing makeup fluid versus connate formation fluid. Work from the MSEEL study in northern West Virginia provided daily water recovery from four wells that indicated relatively low fluid recovery relative to injection (Ziemkiewicz, 2017). This 
confirmed previous results indicating the likelihood that a large percentage of injected fluid had been imbibed or leaked off into the formation (Byrnes, 2011, Roychaudhuri, 2013, Engelder, 2012, Kanfar and Clarkson, 2016, Osselin et al., 2018). Studies focused on TDS suggested that the maximum salinity values in produced water represent undiluted formation water, allowing estimation of the amount of hydraulic fracturing fluid diluting formation water in earlier produced waters (Kondash et al., 2017, Osselin et al., 2018). These studies were applied within the study area to quantify returned fluid over time.

The aforementioned studies provided valuable insight in characterizing produced water across the study area. Many of the studies focused on northeastern and southwestern Pennsylvania as well as northern West Virginia. This study expands these observations into the less well-studied areas of Harrison and Taylor counties. It also provides new data points showing Marcellus shale produced-water trends over longer time periods than previously examined

\section{RESULTS}

The data available for this study were reviewed by first analyzing the well logs across the five areas to determine how the geology changes based on gamma ray and density logs. Next, TOC calculations from the density logs were compared to core-derived TOC values based on pyrolysis to determine the utility of log-calculated values. XRD mineralogy from cores were compared to elemental analysis (ELAN) logs from the cored wells to validate the ELAN mineralogy across the entire Marcellus section of each well. Once the geological parameters were determined, returned fluid analysis was performed to observe the trends in each area and source water and 
produced water analyses results are presented to determine how the water chemistry changes across the study area.

\section{Well Log Analysis}

Well logs for five wells, one in each of the five areas, were analyzed to determine how the geology changes across the study area (Figure 7). Correlations were performed primarily using the gamma-ray logs, and using the higher-resolution, pad-based density logs to pick formation tops more precisely. Three tops were picked in the Marcellus Shale, (upper, middle, and lower), as well as the top of the Onondaga Limestone (Figure 8). Across the study area, the Onondaga was characterized as a transition zone downward from shale, to limey shale, to limestone, and eventually into the Huntersville Chert. This contrasts with the abrupt change from black shale to limestone observed throughout other parts of the basin, such as southwestern Pennsylvania and the northern panhandle of West Virginia (Lash and Engelder, 2011). Within this study area, Marcellus thicknesses ranged from 86 feet (26.2 meters) thick in Harrison Area 1 to 117 feet (35.7 meters) thick in the Northeast Taylor Area. Thicknesses in the other areas were 87 feet (26.5 meters) in Harrison Area 2, 96 feet (29.3 meters) in the Central Taylor Area, and 99 feet (30.2 meters) in the Monongalia Area. This indicated thickening from west to east across the study area. The Northeast Taylor log showed a significantly thicker section than Central Taylor and Monongalia given their west to east proximity.

Repeated sections were evident in the Northeast Taylor log in the Mahantango Formation (Hamilton Group), which overlies the Marcellus. These repeated sections suggest thrust faulting associated with the Chestnut Ridge Anticline. While repeated sections were difficult to distinguish with certainty within the Marcellus in this log, there were likely dips that skewed the 
apparent thickness, making the section appear thicker. So, while the Marcellus was thicker in Northeast Taylor than in Central Taylor and Monongalia, it was likely not on the scale indicated by the log. The effects of the Chestnut Ridge Anticline were also observed when looking at the subsea depth of the study area. The general west to east deepening to the top of the Onondaga held true for the study area until the Northeast Taylor Area. This area was shallower than Central Taylor and Monongalia due to the uplift associated with Chestnut Ridge. Drilling depth to the

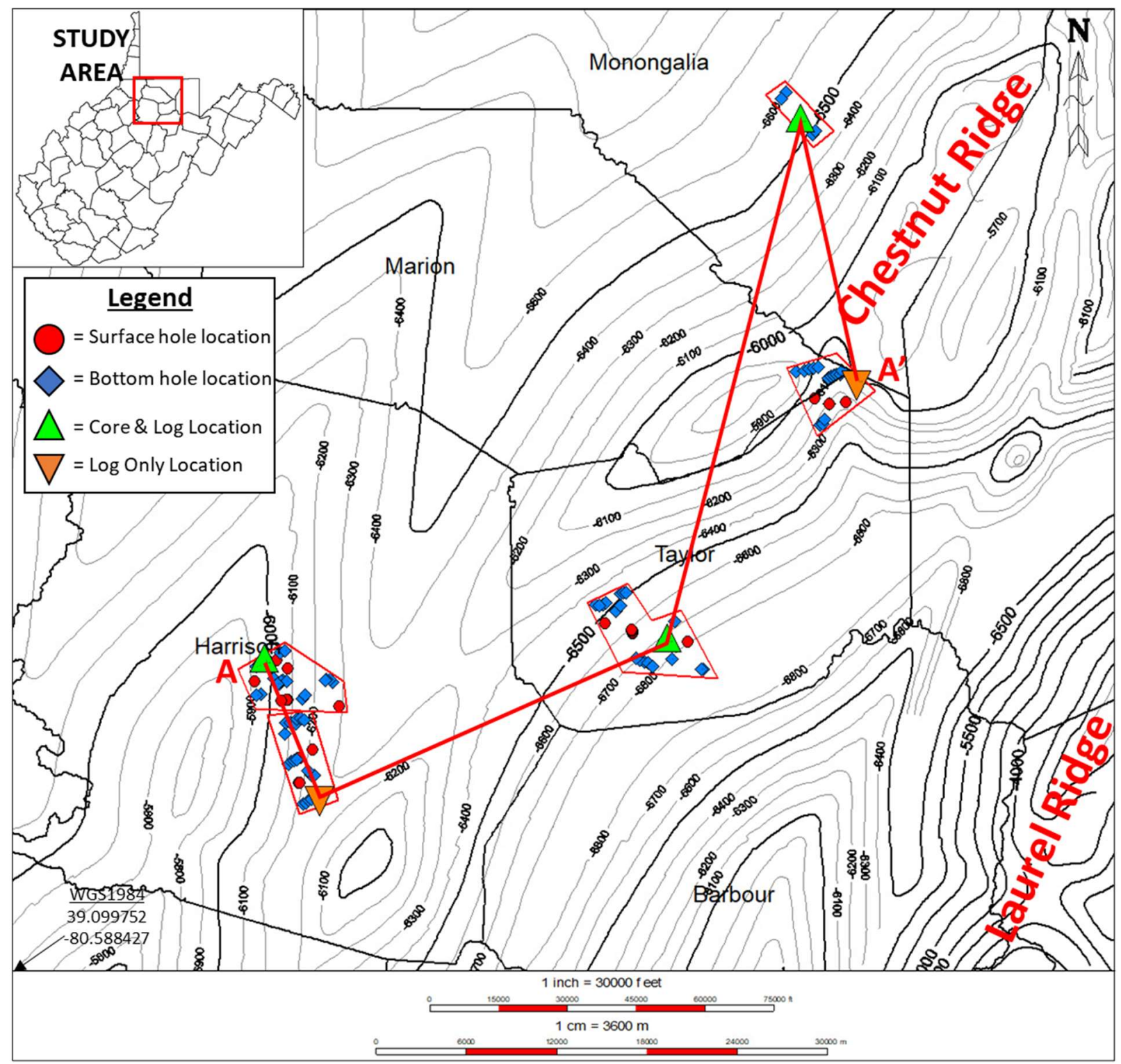

Figure 7 - Location of core and well logs used in this study. Green triangles indicate location of well with core and well logs. Upside-down orange triangles indicate wells with well logs only. (data source: West Virginia Geological and Economic Survey). 


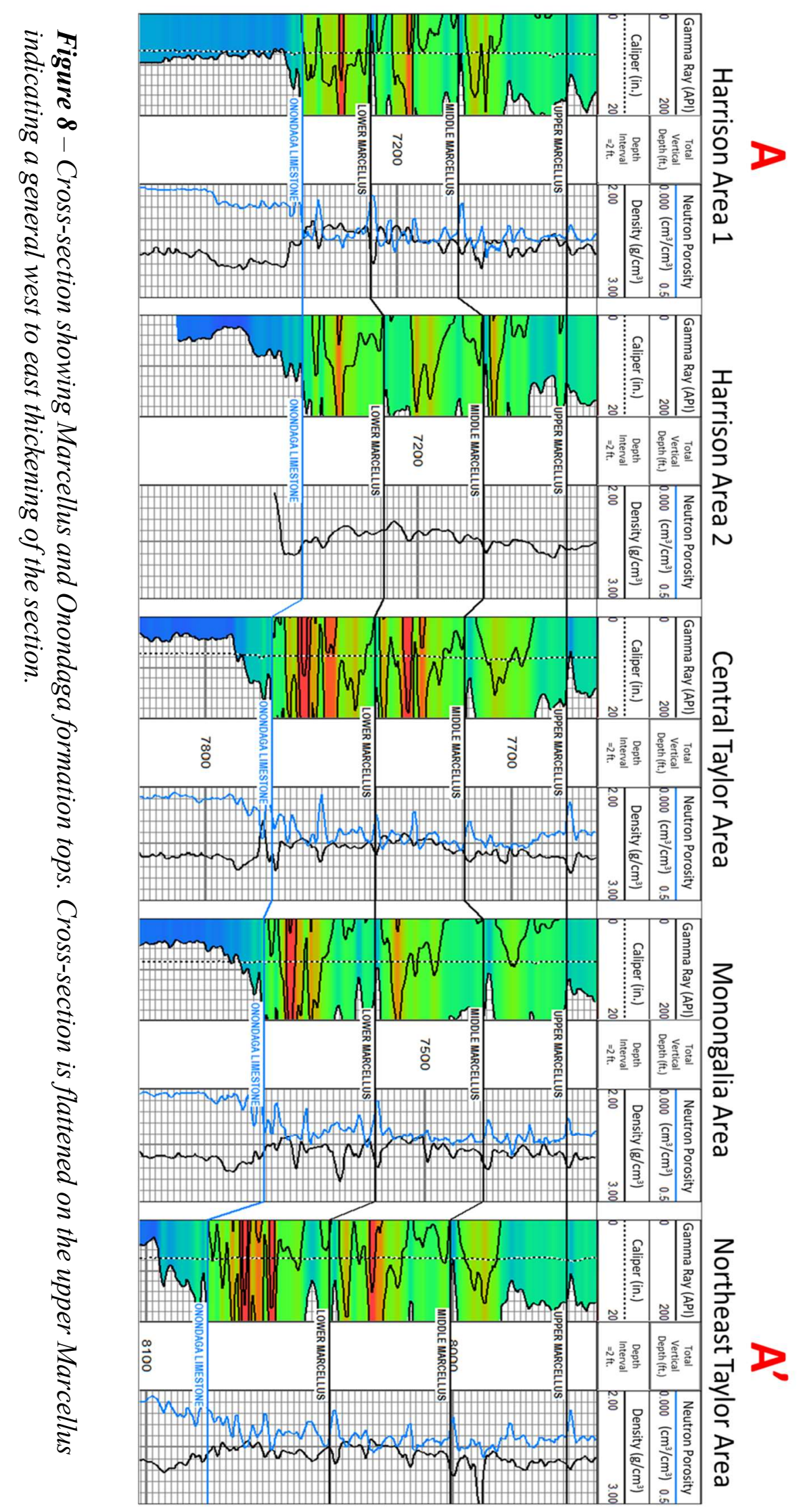


Marcellus, depth subsea, and thickness ranges, as well as data related to gamma-ray intensity, density, and TOC are shown in Table 1.

\begin{tabular}{|c|c|c|c|c|c|}
\hline & Harrison Area 1 & Harrison Area 2 & Central Taylor & Monongalia & Northeast Taylor \\
\hline \multicolumn{6}{|c|}{ UPPER MARCELLUS } \\
\hline Depth (feet) & $7,145-7,180$ & $7,151-7,179$ & $7,682-7,715$ & $7,454-7,481$ & $7,963-8,001$ \\
\hline Depth Subsea (feet) & $(-5,770)-(-5,805)$ & $(-5,977)-(-6,005)$ & $(-6,351)-(-6,384)$ & $(-6,396)-(-6,423)$ & $(-5,965)-(-6,003)$ \\
\hline Thickness (feet) & 35 & 28 & 33 & 27 & 38 \\
\hline Gamma Range (API) & $81-396$ & $97-413$ & $120-356$ & $103-356$ & $81-349$ \\
\hline Density Range $\left(\mathrm{g} / \mathrm{cm}^{3}\right)$ & $2.44-2.74$ & $2.49-2.64$ & $2.55-2.68$ & $2.49-2.72$ & $2.54-2.75$ \\
\hline Core TOC Range (\%) & $0.58-4.71$ & N/A & $2.84-4.34$ & $3.19-5.16$ & N/A \\
\hline Calc TOC Range (\%) & $0.00-5.98$ & $1.29-4.81$ & $0.33-3.34$ & $0.00-4.82$ & $0.00-3.52$ \\
\hline \multicolumn{6}{|c|}{ MIDDLE MARCELLUS } \\
\hline Depth (feet) & $7,180-7,209$ & $7,179-7,211$ & $7,715-7,745$ & $7,481-7,517$ & $8,001-8,041$ \\
\hline Depth Subsea (feet) & $(-5,805)-(-5,834)$ & $(-6,005)-(-6,037)$ & $(-6,384)-(-6,414)$ & $(-6,423)-(-6,459)$ & $(-6,003)-(-6,043)$ \\
\hline Thickness (feet) & 29 & 32 & 30 & 36 & 40 \\
\hline Gamma Range (API) & $35-482$ & $148-395$ & $139-591$ & $83-513$ & $119-544$ \\
\hline Density Range $\left(\mathrm{g} / \mathrm{cm}^{3}\right)$ & $2.37-2.70$ & $2.32-2.53$ & $2.41-2.61$ & $2.43-2.70$ & $2.44-2.69$ \\
\hline Core TOC Range (\%) & $1.70-6.85$ & N/A & $5.26-5.84$ & $2.60-7.21$ & $\mathrm{~N} / \mathrm{A}$ \\
\hline Calc TOC Range (\%) & $0.00-7.66$ & $3.68-9.09$ & $1.99-6.61$ & $0.07-6.27$ & $0.14-5.96$ \\
\hline \multicolumn{6}{|c|}{ LOWER MARCELLUS } \\
\hline Depth (feet) & $7,209-7,231$ & $7,211-7,238$ & $7,745-7,778$ & $7,517-7,553$ & $8,041-8,080$ \\
\hline Depth Subsea (feet) & $(-5,834)-(-5,856)$ & $(-6,037)-(-6,064)$ & $(-6,414)-(-6,447)$ & $(-6,459)-(-6,495)$ & $(-6,043)-(-6,082)$ \\
\hline Thickness (feet) & 22 & 27 & 33 & 36 & 39 \\
\hline Gamma Range (API) & $141-534$ & $99-461$ & $182-718$ & $118-740$ & $120-770$ \\
\hline Density Range $\left(\mathrm{g} / \mathrm{cm}^{3}\right)$ & $2.33-2.58$ & $2.37-2.56$ & $2.46-2.74$ & $2.43-2.83$ & $2.44-2.62$ \\
\hline Core TOC Range (\%) & $5.91-8.03$ & $\mathrm{~N} / \mathrm{A}$ & $2.42-5.12$ & $1.8-10.91$ & $\mathrm{~N} / \mathrm{A}$ \\
\hline Calc TOC Range (\%) & $2.65-8.77$ & $3.10-7.91$ & $0.59-5.51$ & $0.69-6.24$ & $1.65-5.87$ \\
\hline $\begin{array}{l}\text { TOTAL MARCELLUS } \\
\text { THICKNESS (Feet) }\end{array}$ & 86 & 87 & 96 & 99 & 117 \\
\hline
\end{tabular}

Table 1 - Depth, thickness, gamma ray, density, and TOC ranges for the upper, middle, and lower Marcellus taken from the well logs in each of the five areas in this study.

In addition to overall thickness increasing from west to east, a few other trends were determined from the well log correlation. Upper Marcellus thickness was relatively consistent throughout the study area, with signs of slight thinning from west to east with Northeast Taylor being an exception. Conversely, both the middle Marcellus and lower Marcellus displayed thickening from west to east. This was most evident in the lower Marcellus, which is 22 feet (6.7 meters) thick in Harrison Area 1 and thickened to 39 feet (11.9 meters) in Northeast Taylor. Thickening 
in the middle Marcellus was not as extreme, with 29 feet (8.8 meters) in Harrison Area 1 and 40 feet (12.2 meters) in Northeast Taylor. The general west to east thickening trends further complimented and expanded previous works that predicted thickening trends across the study area (Ettensohn, 1985, Lash and Engelder, 2011, and Zagorski, 2017).

Other than thickness trends, the intensity of the gamma-ray logging response displayed trends across the study area. Except for Harrison Area 2, the upper Marcellus had the lowest gammaray intensity in each area (349 API - 413 API), followed by the middle Marcellus (395 API 591 API). Each area showed the "hottest" gamma-ray response in the lower Marcellus (461 770 API). This pattern indicated decreasing gamma-ray intensity moving up through the formation. In addition to stratigraphic differences in gamma-ray logging values, spatial variations are also observed. Harrison Area 1 had a maximum upper Marcellus gamma-ray logging value of 396 API, while Harrison Area 2 had a maximum upper Marcellus value of 413, Central Taylor was 356 API, Northeast Taylor was 349 API, and Monongalia was 356 API. These values indicated that gamma-ray intensity decreases slightly from west to east, but with a range of only 64 API. The middle Marcellus showed the opposite with gamma-ray logging values increasing from west to east. Harrison Area 2 had the lowest-maximum middle Marcellus gamma-ray value of 395 API, followed by Harrison Area 1 (482 API), Monongalia (544 API), Northeast Taylor (544 API) and Central Taylor with the highest-maximum middle Marcellus value of 591 API. The gamma-ray spread in the middle Marcellus was 196 API, much higher than the spread observed in the upper Marcellus. Gamma-ray logging values in the lower Marcellus followed a west to east intensifying trend similar to that of the middle Marcellus with the lowest-maximum value in Harrison Area 2 (461 API) followed by Harrison Area 1 (534 
API), Central Taylor (718 API), Monongalia (740 API), and the highest-maximum value in Northeast Taylor (770 API). The highest gamma-ray spread occurred in the lower Marcellus with 309 API units separating the lowest-maximum in Harrison Area 2 and the highest-maximum in Northeast Taylor. Gamma-ray values are summarized in Table 1 and west to east trends can be viewed in well $\log$ cross-section (Figure 8).

Gamma-ray logs are useful tools for correlating formation tops and determining thicknesses. Density logs are useful for correlating formations in combination with gamma-ray logs by determining changes in density associated with lithology changes. However, density logs are primarily used for estimating rock properties such as porosity, particularly in sandstones, and TOC in organic-rich shale due to the presence of less dense kerogen (Schmoker, 1979). Across the study area, the minimum density ranges for the Marcellus increased upwards from the lower Marcellus $\left(2.33 \mathrm{~g} / \mathrm{cm}^{3}\right.$ to $\left.2.46 \mathrm{~g} / \mathrm{cm}^{3}\right)$ to the middle Marcellus $\left(2.32 \mathrm{~g} / \mathrm{cm}^{3}\right.$ to $\left.2.44 \mathrm{~g} / \mathrm{cm}^{3}\right)$ to the upper Marcellus $\left(2.44 \mathrm{~g} / \mathrm{cm}^{3}\right.$ to $\left.2.55 \mathrm{~g} / \mathrm{cm}^{3}\right)$. This indicated a general trend of decreasing kerogen content upwards in the Marcellus Shale as kerogen is lighter, resulting in a lower density. Similar to gamma-ray values, density varied not only upwards through the Marcellus Shale, but across the study area as well. In the upper Marcellus, Harrison Area 1 had the lowest density at $2.44 \mathrm{~g} / \mathrm{cm}^{3}$, followed by Harrison Area 2 and Monongalia, both at $2.49 \mathrm{~g} / \mathrm{cm}^{3}$. Northeast Taylor had a minimum upper Marcellus density of $2.54 \mathrm{~g} / \mathrm{cm}^{3}$ and Central Taylor had the highestminimum upper Marcellus density at $2.55 \mathrm{~g} / \mathrm{cm}^{3}$. These densities indicated a general trend of increasing density from west to east in the upper Marcellus. The middle Marcellus displayed a similar trend with the lowest-minimum density in Harrison Area $2\left(2.32 \mathrm{~g} / \mathrm{cm}^{3}\right)$, followed by Harrison Area $1\left(2.33 \mathrm{~g} / \mathrm{cm}^{3}\right)$, then Central Taylor $\left(2.41 \mathrm{~g} / \mathrm{cm}^{3}\right)$, Northeast Taylor $\left(2.43 \mathrm{~g} / \mathrm{cm}^{3}\right)$, 
and Monongalia $\left(2.44 \mathrm{~g} / \mathrm{cm}^{3}\right)$. While the upper Marcellus and middle Marcellus shared similar trends of increasing density from west to east, the range of densities showed less variation in the middle Marcellus. Across the study area, the lower Marcellus displayed increasing densities from west to east with values similar to the middle Marcellus. Harrison Area 1 had the lowestminimum density at $2.33 \mathrm{~g} / \mathrm{cm}^{3}$ followed by Harrison Area $2\left(2.37 \mathrm{~g} / \mathrm{cm}^{3}\right)$, Northeast Taylor $\left(2.43 \mathrm{~g} / \mathrm{cm}^{3}\right)$, Monongalia $\left(2.44 \mathrm{~g} / \mathrm{cm}^{3}\right)$ and Central Taylor $\left(2.46 \mathrm{~g} / \mathrm{cm}^{3}\right)$. In the case of both gamma ray and density values, there were distinct trends not only within the Marcellus itself, but also across the study area. Harrison Area 1 and Harrison Area 2 had lower gamma-ray values than the Central Taylor, Northeast Taylor, and Monongalia areas. Minimum densities were also lower in the Harrison areas than in the other three areas. When considering only the Central Taylor, Northeast Taylor, and Monongalia areas, similar values for gamma ray and density were observed with no distinct trends among the three areas.

Studies performed on Appalachian Devonian shale have looked at the relationship between gamma-ray intensity and density as well as the relationship between density and TOC (Schmoker, 1979, 1981, and 1993). Analysis of the five well logs across the study area indicated a relationship that as gamma-ray intensity increased, formation density decreased, which is consistent with Schmoker's (1981) work looking at organic-rich, black shales in the western Appalachian basin (Figure 9). This positive relationship between gamma-ray intensity and density was demonstrated across the study area (Figure 9). The highest gamma-ray intensities were observed in Central Taylor, Northeast Taylor and Monongalia along with noticeably lower gamma-ray intensities in the two Harrison areas where only a few points exceeded 500 API. 
Regarding density, minimum readings for both Harrison areas were below $2.40 \mathrm{~g} / \mathrm{cm}^{3}$, whereas the other three areas did not drop below that level (Figure 9).

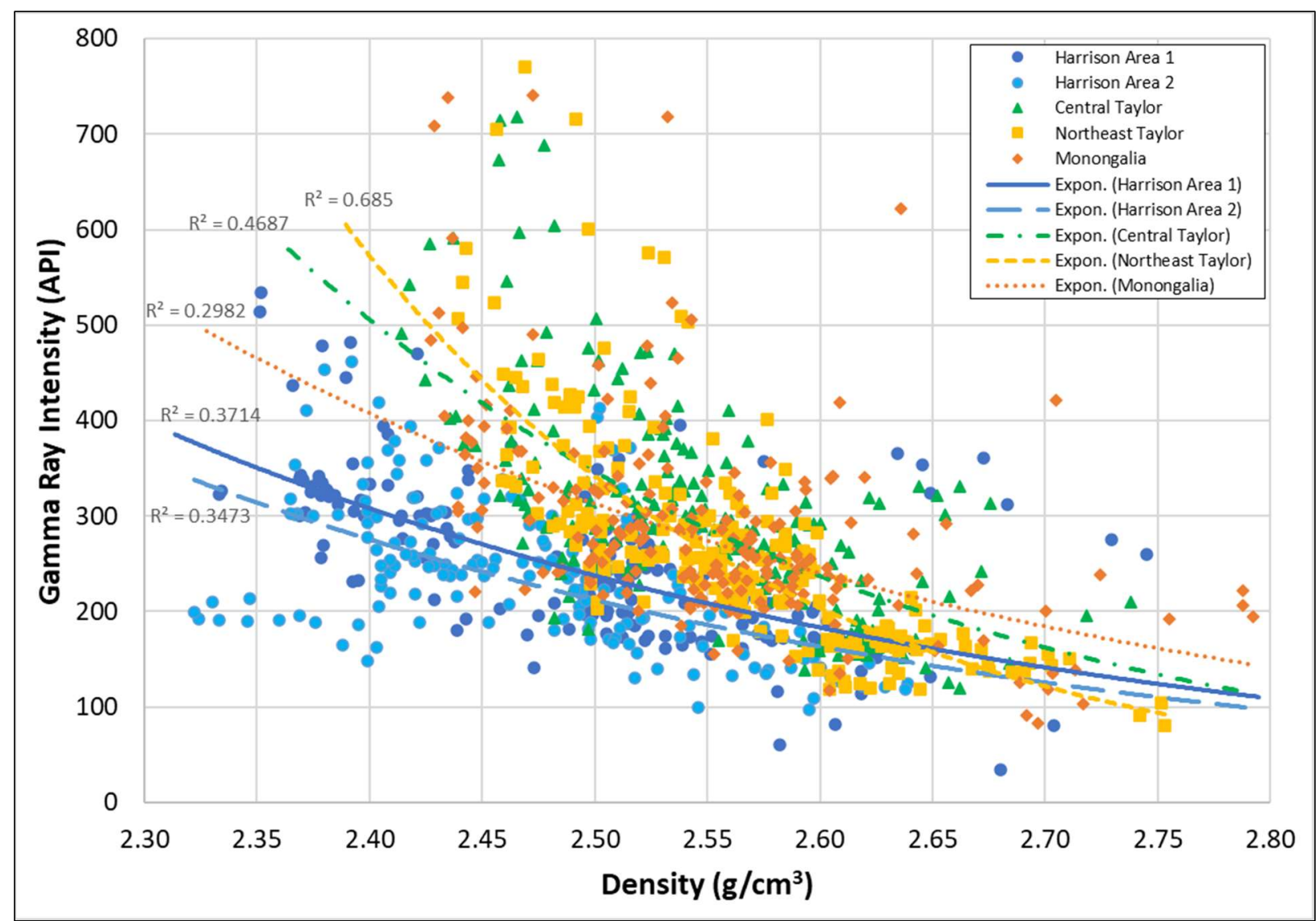

Figure 9-Relationship between gamma-ray intensity and density in the Marcellus Shale for the five well logs across the study area. Trendlines indicate that in each area, as gamma-ray intensity increases, density decreases but at different exponential rates.

\section{Estimating TOC using Pyrolysis and Density Logs}

Pyrolysis TOC data were obtained from cores taken in Harrison Area 1, Central Taylor, and Monongalia areas. Weatherford Labs performed the pyrolysis on the Harrison Area 1 and Central Taylor cores. Paronish (2018) performed the pyrolysis on the Monongalia core as part of the MSEEL project. TOC values estimated via pyrolysis were compared to log-calculated TOC values using the Schmoker equation to verify if they agree. This is important because determination of TOC by pyrolysis is not sampled continuously. Use of density logs, on the other 
hand, allows a continuous TOC record. Therefore, comparing core to log-calculated TOC values allows calibration of the log-calculated data.

Schmoker $(1979,1993)$ looked at density logs of organic-rich, black shales and developed an equation to calculate estimated TOC using the density log and regional, non-organic shale densities. TOC was estimated from density logs using the equation:

$$
\operatorname{TOC}(\%)=55.822\left[\left(\rho_{\mathrm{B}} / \rho\right)-1\right],
$$

where TOC $\%$ is the weight percent of organic carbon, $\rho_{\mathrm{B}}$ is the most-dense interval of nonorganic, gray shale, and $\rho$ is the density of the organic-rich black shale obtained from the log (Schmoker, 1993). Values for $\rho_{\text {в }}$ are typically between $2.67 \mathrm{~g} / \mathrm{cm}^{3}$ and $2.72 \mathrm{~g} / \mathrm{cm}^{3}$ for Appalachian basin Devonian shale units (Schmoker, 1993). For the five wells in the study area, a $\rho_{B}$ value of $2.70 \mathrm{~g} / \mathrm{cm}^{3}$ was determined from shale intervals in both the Hamilton Group and Harrell Shale above the Burkett and Tully formations. Comparing gamma-ray intensities to the log-calculated TOC values for the study area, as gamma-ray values increase, log-calculated TOC generally increases (Figure 10). This indicates that as the density in the black shale decreases, the log-calculated TOC \% increases, consistent with the results of Schmoker (1979, 1981 and 1993). Figure 10 indicates that the highest TOC values should be in the Harrison areas with values reaching as high as $9.0 \%$, while the other three areas should have maximum TOC values between $6 \%-7 \%$.

The core from Harrison Area 1 was sampled at nine depths within the 86-foot thick (26.2 meter) Marcellus section. Three samples were taken from each of the upper, middle, and lower Marcellus. Pyrolysis TOC ranged over the entire Marcellus from 0.58 - 8.03\% (Table 1). The 


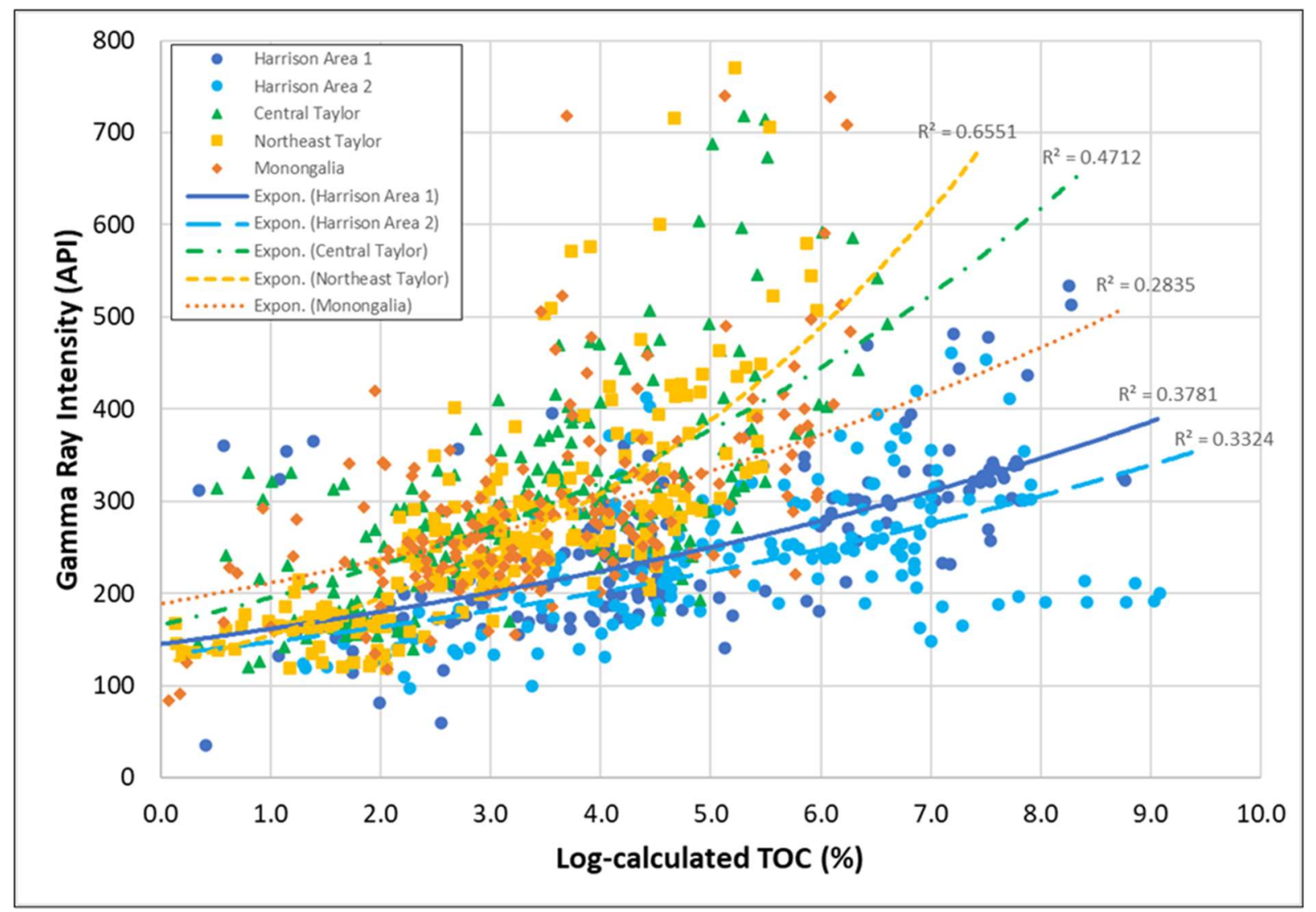

Figure 10 - Relationship between gamma-ray intensity and log-calculated TOC in the Marcellus Shale for the five well logs across the study area. Trendlines indicate that in each area, as gamma-ray intensity increases, log-calculated TOC increases but at different exponential rates. Individual plots for each area are in Appendix A.

TOC range was $0.58-4.71 \%, 1.70-3.98 \%$, and $5.91-8.03 \%$ within the upper, middle, and lower Marcellus, respectively. Since log values were averaged over 0.5 feet ( 0.15 meters) intervals while the core values were measured using a 0.1 foot ( 0.03 meters $)$ or less core slab, exact agreement was unlikely due to sampling bias. A plot of pyrolysis TOC versus logcalculated TOC indicates a general agreement between the two methods for Harrison Area 1 (Figure 11).

The core from Central Taylor was sampled at eight depths within the 96-foot thick (29.3 meter) Marcellus section. Two samples were taken from both the upper and middle Marcellus and four 


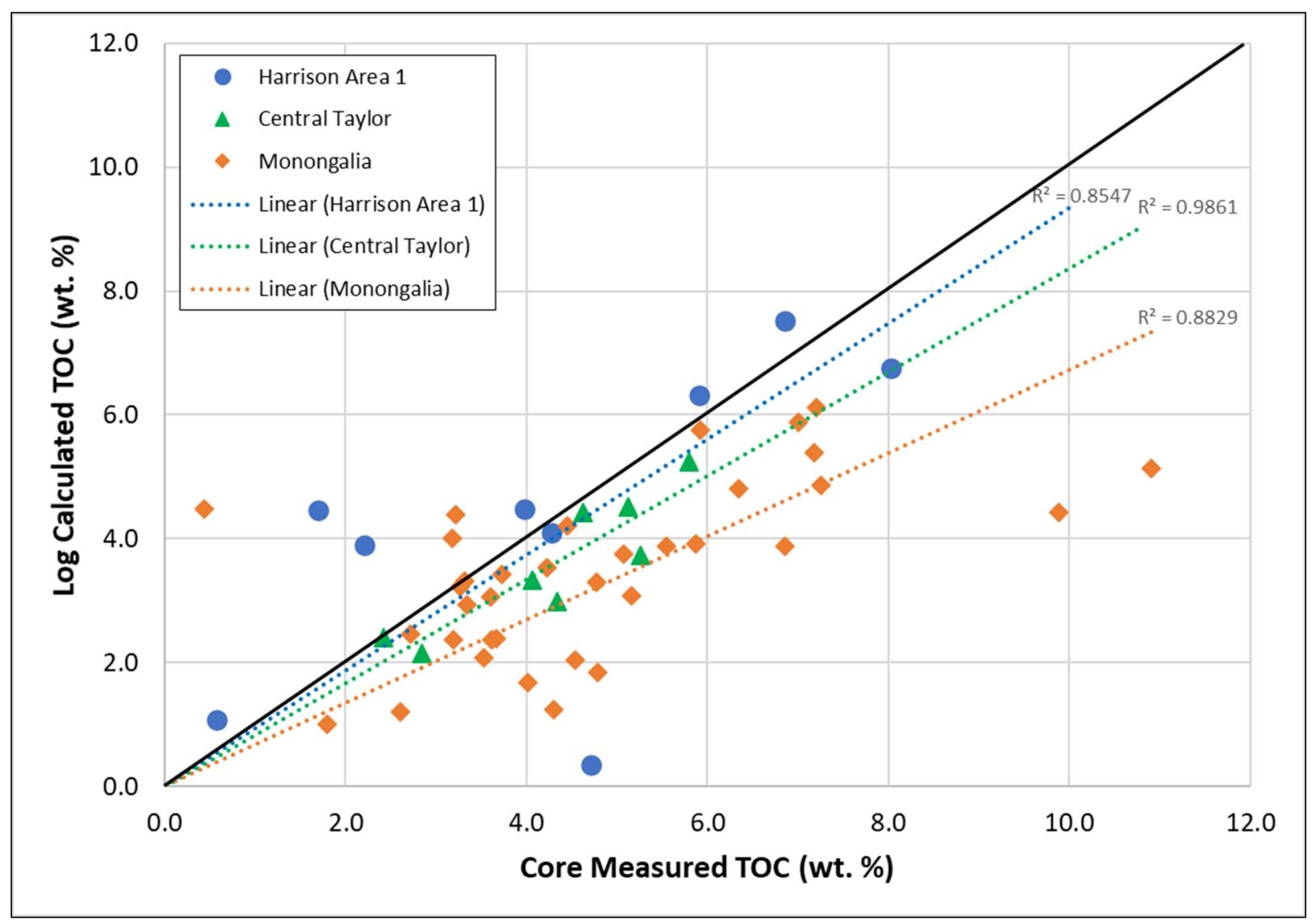

Figure 11 - Comparison of core-obtained TOC and log-calculated TOC in the Marcellus Shale for the three cores located in the study area. The unit-slope line indicates that there is a general agreement between the two methods of obtaining TOC values with log-calculated TOC slightly underestimated in the Central Taylor and Monongalia areas.

samples from the lower Marcellus. Pyrolysis TOC ranged over the entire Marcellus from 2.42 $5.84 \%$. The TOC $\%$ was $2.84-4.06 \%, 4.34-5.84 \%$ and $2.42-5.26 \%$ within the upper, middle, and lower Marcellus, respectively. There are few low TOC values for Central Taylor, likely due to sampling bias toward sections with higher gamma ray/lower density values that tend to have higher TOC. These points plot slightly below the unit-slope line indicating that the log-calculated values slightly underestimate TOC based on pyrolysis (Figure 11), likely due to sampling bias.

The core for the Monongalia Area was part of the MSEEL project and subject to more extensive study than the Harrison and Central Taylor cores. Thirty-five pyrolysis samples were run within 
the 99-foot (30.2 meter) thick Marcellus section. Of the samples tested, 10 were within the upper Marcellus, 13 in the middle Marcellus and 12 in the lower Marcellus, so each section was well represented. Pyrolysis TOC ranged over the entire Marcellus from $1.80-10.91 \%$. The TOC \% range was $3.19-5.16 \%, 2.60-7.21 \%$, and $1.80-10.91 \%$ within the upper, middle, and lower Marcellus respectively. When comparing the log-calculated TOC to the core-derived TOC, there was a slight underestimation using the log-calculated method (Figure 11). With many more samples being tested in this core, it was likely that localized high-TOC zones would be seen in the core, while the density log used for the log calculation was averaged over a larger interval, which can suppress localized high TOC, low density sections. Core-to-log depth shifting may also be a factor. Underestimation may also have occurred due to the relatively higher logobtained density values used in the Schmoker equation.

Although there is no core data available for Harrison Area 2 and Northeast Taylor, they were compared to the cores used in this study to determine if similar trends exist. Having shown that the log-calculated TOC for Harrison Area 1 was a good representation of core-derived TOC, it can be compared to log-calculated TOC values for Harrison Area 2. The log-calculated TOC values for Harrison Area 2 compared well to the log-calculated TOC values from the Harrison Area 1 (Figure 12). For the Northeast Taylor area, log-calculated TOC was compared to those values for Central Taylor and Monongalia areas. There is a close correlation for all data points among all three areas. When trendlines were compared, Central Taylor is most similar to Northeast Taylor (Figure 13). One factor to consider, however, is that log-calculated TOC was slightly underestimated when compared to pyrolysis TOC for the Central Taylor and Monongalia areas (Figure 11). While the log-calculated TOC for Northeast Taylor provided a reasonable 


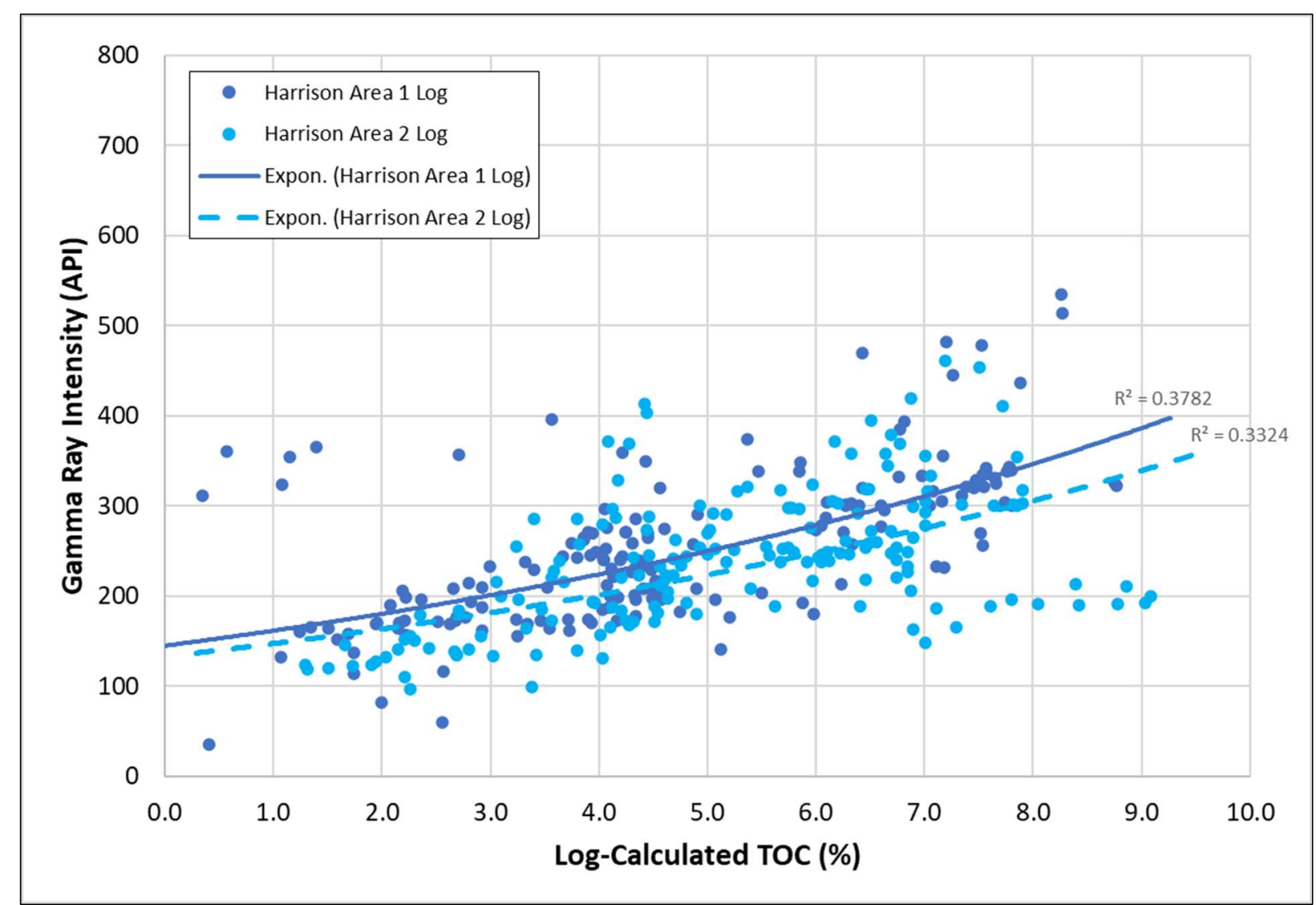

Figure 12 - Relationship between Harrison Area 1 log-calculated TOC and Harrison Area 2 log-calculated TOC in the Marcellus Shale. Trendlines indicate similar behaviors with values close enough to assume Harrison Area 1 and Harrison Area 2 share similar TOC characteristics.

estimation, it likely underestimated the actual TOC values for the same reasons considered above.

Core and log-calculated TOC vs. gamma ray plots for each area are found in Appendix A.

Pyrolysis TOC values were relatively similar across the study area with differences caused by sampling bias, scale, and sample density. Log-calculated TOC values varied between the areas, due to increasing density from west to east that resulted in underestimating log-calculated TOC in Central Taylor, Northeast Taylor, and Monongalia. Higher log-calculated TOC values were found in Harrison areas 1 and 2, despite lower gamma-ray values than the other three areas. This 
contradicts Schmoker's (1981) conclusion that higher TOC values correlate to higher gamma-ray values.

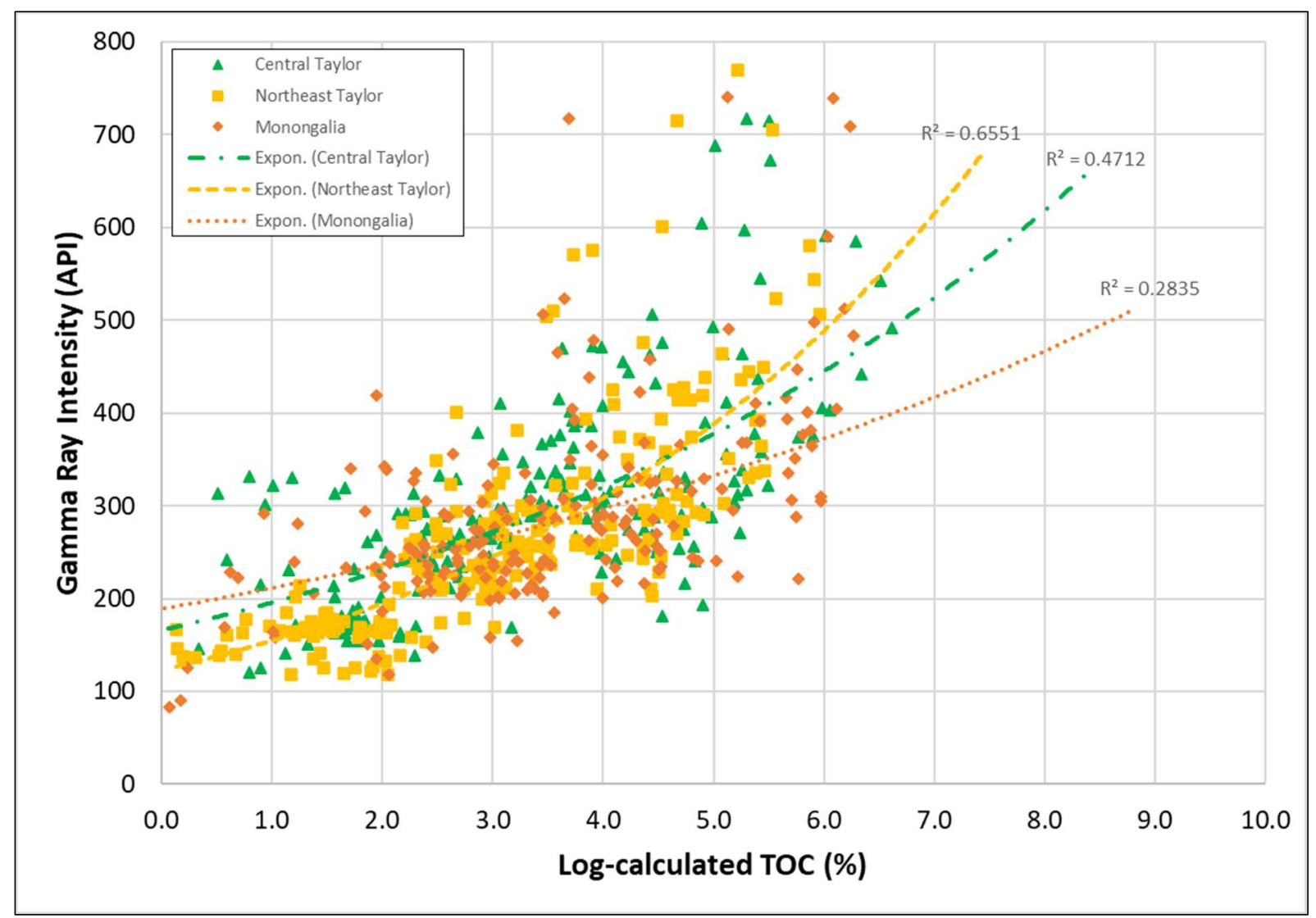

Figure 13 - Relationship between Central Taylor, Monongalia, and Northeast Taylor logcalculated TOC values in the Marcellus Shale. Trendlines indicate similar behaviors with values close enough to assume Central Taylor and Northeast Taylor areas share similar TOC characteristics.

\section{XRD Comparison}

Varying XRD mineral concentrations correspond to variations in concentrations of ions such as $\mathrm{Ba}, \mathrm{Ca}$, and $\mathrm{Sr}$ in produced water (Dresel and Rose, 2010). Mineralogy has a significant impact on the effectiveness of hydraulic fracturing and resulting hydrocarbon production due to the brittleness of various minerals. XRD data was available for the cores in Harrison Area 1, Central Taylor, and Monongalia. Harrison Area 1 and Central Taylor areas were limited to only nine and eight sampling points within the Marcellus Shale, respectively. Core Lab performed the XRD 
analysis on these two cores. Extensive XRD analysis was performed on the Monongalia core (Hupp, 2017 and Hupp and Donovan, 2018) and were compared to ELAN logs to determine the accuracy of the logs for expansion across the entire Marcellus interval of each well. Mineralogy data was also compared to produced-water samples to determine if produced water can be predicted by relative concentrations of minerals present. As was the case with TOC, core-derived XRD results are taken from 0.1 foot $(0.03$ meters $)$ or less core slabs, while ELAN logs were averaged across 6 -inch $(15.2-\mathrm{cm})$ intervals.

XRD analysis and ELAN logs correlated relatively well with quartz content in the upper, middle, and lower Marcellus sections in Harrison Area 1 with differences in the upper values up to 6.4\% (Table 2). ELAN logs overestimated clay content in each section compared to XRD mineralogy with differences ranging from $16.2 \%$ to $20.5 \%$. Comparing ELAN results to XRD results for carbonate ranges showed an underestimation in the upper Marcellus, overestimation in the lower Marcellus, and similar values in the middle Marcellus. Pyrite and barite were both underestimated on the ELAN log compared to XRD. These differences may have resulted due to sampling density bias. Only nine core samples were run for XRD while the ELAN log average resolution was $0.5 \mathrm{ft}$. $(15.2 \mathrm{~cm})$. Small sample density in the core leads to a higher chance of missing high weight \% zones picked up by the ELAN log.

To better visualize the mineralogy data, core-derived values and log-derived values for quartz, clay, and carbonates were plotted on a ternary diagram (Figure 14A). The diagram shows that seven of the sample points for Harrison Area 1 contained predominately quartz and clay minerals with relatively low carbonate. Two samples showed significant carbonate content. The log- 


\begin{tabular}{|c|c|c|c|c|c|c|}
\hline & \multicolumn{2}{|c|}{ Harrison Area 1} & \multicolumn{2}{|c|}{ Central Taylor } & \multicolumn{2}{|c|}{ Monongalia } \\
\hline & $\begin{array}{c}\text { Core XRD } \\
\text { (wt.\%) }\end{array}$ & $\begin{array}{c}\text { ELAN Log } \\
\text { (wt.\%) }\end{array}$ & $\begin{array}{c}\text { Core XRD } \\
\text { (wt.\%) }\end{array}$ & $\begin{array}{c}\text { ELAN Log } \\
\text { (wt.\%) }\end{array}$ & $\begin{array}{c}\text { Core XRD } \\
\text { (wt.\%) }\end{array}$ & $\begin{array}{c}\text { ELAN Log } \\
\text { (wt.\%) }\end{array}$ \\
\hline \multicolumn{7}{|c|}{ UPPER MARCELLUS } \\
\hline Depth (feet) & \multicolumn{2}{|c|}{$7,145-7,180$} & \multicolumn{2}{|c|}{$7,682-7,715$} & \multicolumn{2}{|c|}{$7,454-7,481$} \\
\hline Quartz + Feldspars & $6.4-53.5$ & $20.2-53.6$ & $37.9-48.9$ & $24.5-51.7$ & $17.0-37.0$ & $17.5-78.8$ \\
\hline Clay & $7.8-46.2$ & $23.4-66.7$ & $36.7-43.3$ & $34.1-65.7$ & $40.0-78.0$ & $12.0-68.1$ \\
\hline Calcite + Dolomite & $0.4-84.1$ & $0.0-54.6$ & $6.1-8.5$ & $0.0-31.6$ & $0.0-24.0$ & $0.0-23.8$ \\
\hline \begin{tabular}{|l|} 
Pyrite \\
\end{tabular} & $1.7-12.8$ & $0.0-10.5$ & $6.0-16.1$ & $0.4-12.7$ & $3.0-14.0$ & $0.0-10.7$ \\
\hline Barite & $0-1.3$ & $0.0-0.6$ & N/A & $0.0-2.6$ & $0.0-3.0$ & $0.0-1.4$ \\
\hline \multicolumn{7}{|c|}{ MIDDLE MARCELLUS } \\
\hline Depth (feet) & \multicolumn{2}{|c|}{$7,180-7,209$} & \multicolumn{2}{|c|}{$7,715-7,745$} & \multicolumn{2}{|c|}{$7,481-7,517$} \\
\hline Quartz + Feldspars & $16.8-49.5$ & $13.1-55.9$ & $50.5-61.6$ & $15.7-54.6$ & $15.0-40.0$ & $24.9-63.9$ \\
\hline Clay & $7.4-34.9$ & $8.7-51.1$ & $25.1-26.4$ & $21.9-58.5$ & $39.0-60.0$ & $7.5-58.8$ \\
\hline Calcite + Dolomite & $6.4-72.5$ & $0.0-74.2$ & $3.6-14.4$ & $0.0-56.1$ & $0.0-33.0$ & $0.0-63.6$ \\
\hline Pyrite & $2.4-15.6$ & $0.0-11.6$ & $8.5-9.9$ & $3.6-12.4$ & $6.0-19.0$ & $2.1-13.6$ \\
\hline Barite & $0.0-0.7$ & $0.0-0.2$ & N/A & $0.0-0.4$ & $0.0-4.0$ & $0.0-0.6$ \\
\hline \multicolumn{7}{|c|}{ LOWER MARCELLUS } \\
\hline Depth (feet) & \multicolumn{2}{|c|}{$7,209-7,231$} & \multicolumn{2}{|c|}{$7,745-7,778$} & \multicolumn{2}{|c|}{$7,517-7,553$} \\
\hline Quartz + Feldspars & $36.2-60.4$ & $25.7-64.2$ & $5.5-63.6$ & $9.8-50.3$ & $9.0-39.0$ & $27.9-58.1$ \\
\hline Clay & $6.7-22.5$ & $11.8-42.1$ & $0-19.9$ & $14.0-62.4$ & $0.0-59.0$ & $5.5-53.6$ \\
\hline Calcite + Dolomite & $8.7-41.0$ & $0.0-61.5$ & $5.4-94.1$ & $0.3-73.1$ & $3.0-79.0$ & $0.1-54.6$ \\
\hline Pyrite & $8.2-15.3$ & $0.9-7.9$ & $0.4-11.9$ & $1.0-13.9$ & $3.0-21.0$ & $0.7-14.5$ \\
\hline Barite & $0.0-0.6$ & $0.0-0.1$ & $\mathrm{~N} / \mathrm{A}$ & $0.0-1.1$ & $0.0-16.0$ & $0.0-2.5$ \\
\hline
\end{tabular}

Table 2 - Core-derived XRD and ELAN log mineralogy for the upper, middle, and lower Marcellus taken from wells in Harrison Area 1, Central Taylor, and Monongalia. Core and ELAN logs are not available for Harrison Area 2 and Northeast Taylor.

derived and XRD values were in generally good agreement with the log-derived quartz and clay content accounting for $40 \%$ to $60 \%$ in most samples. Carbonates typically accounted for less than $30 \%$, with many points near $0 \%$. Few data points fell below $30 \%$ percent quartz or exceeded $60 \%$ clay, indicating that quartz and clay were in relatively similar proportions. Data points with elevated carbonate represent the limey sections that are interbedded with the upper, middle, and lower Marcellus units.

XRD data in the Central Taylor Area also suggest predominately quartz and clay prevalence with minor amounts of carbonates (Figure 14B). One data point in this interval represents nearly pure carbonate rock with $<10 \%$ quartz and no clay. Compared to the ELAN mineralogy, there was some agreement although either the XRD data slightly overestimated quartz content or the log- 

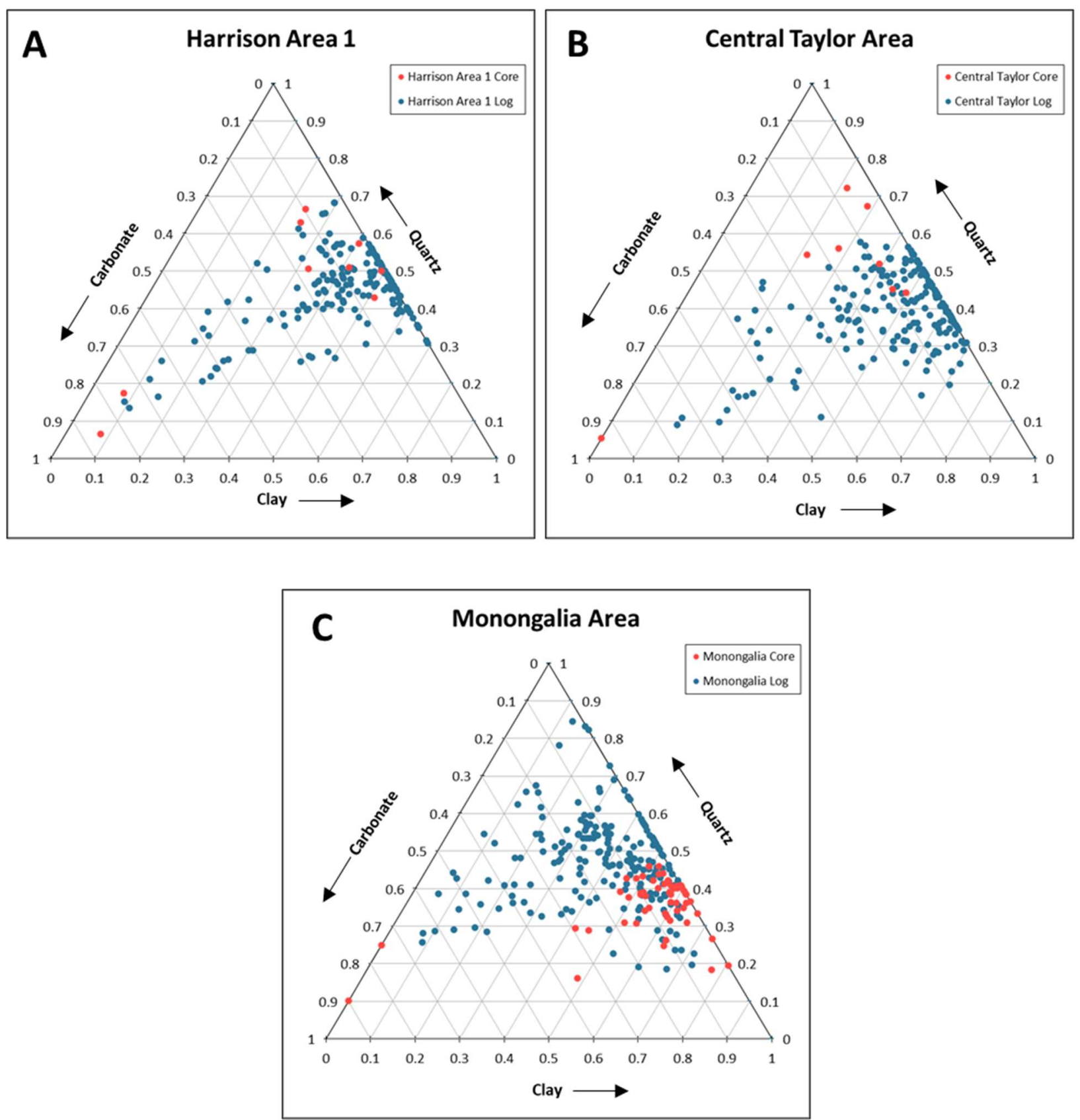

Figure 14- Ternary diagrams showing relationship among quartz, clay, and carbonate minerals from core-derived XRD and log-derived ELAN analysis. A). Harrison Area 1 shows a good correlation between core and log data. B.) Central Taylor shows an acceptable correlation with a possible underestimation of quartz in the log data. C.) Monongalia Area shows poor correlation at high quartz values, but good correlation at lower quartz values indicating a possible overestimation of quartz in the log data. 
derived ELAN data slightly underestimated quartz content. In Central Taylor, quartz and clay minerals were the predominate minerals with carbonates typically making up less than $30 \%$. In samples with little to no carbonate, quartz values ranged from around $30 \%$ up to about $55 \%$ with no values over $60 \%$, indicating a larger proportion of clay minerals. This contrasted with Harrison Area 1, where quartz content was higher (Figure 14A).

In the Monongalia Area, XRD was run on 55 sample points from the core and provided a more robust data set to compare to the log-derived data. A comparison of core-derived XRD data and log-derived data indicated that log-derived data may overestimate quartz and underestimate clays (Figure 14C). The core-derived data correlate well with a portion of the log-derived data indicating there is some usefulness to the log data, but potential overestimation of quartz is likely. The lower quartz and higher clay content were similar to results for the Central Taylor Area, whereas Harrison Area 1 indicated a relatively higher quartz content.

\section{Fluid Recovery Behavior}

Studies looking at the fate of injected fluid after hydraulic fracturing have concluded that $100 \%$ fluid recovery in unlikely due to imbibition and natural leak-off of fluid into the formation (Byrnes, 2011, Engelder, 2012, Roychaudhuri, 2013). Estimates of returned fluid ranged from less than 50\% (Engelder, 2012), to 30\% $\pm 10 \%$ (Byrnes, 2011), and 24\% within the first 80 days (Roychaudhuri, 2013). These estimates do not consider production trends that typically result in forcing more fluid to the surface such as extended shut-in periods that induce higher well pressures or offset hydraulic fracturing that can influence behavior in neighboring wells. Regardless of factors influencing fluid recovery behavior, the wells in this study fell within these 
estimates. The maximum fluid returned from any well was 39.3\%. A further look at fluid recovery among the wells in this study showed that fluid recovery varies from area to area but tended to be consistent within a given area. Daily water production obtained from Arsenal Resources and the MSEEL project began on the first day fluid was returned after hydraulic fracturing until September $3^{\text {rd }}, 2020$. Some wells in Harrison and Taylor counties had minor data gaps. The data gaps were well after initial flowback during periods of lower fluid production so the gaps represented a small fraction of the overall fluid returned and relative to the total amount of fluid returned, did not significantly impact the percentage of fluid returned.

Before considering the percent of fluid returned, it is important to note a couple of important developments in shale well drilling. Technical experience, technology, and the need for better economics resulted in the drilling of extended-reach, horizontal wells that have increasingly longer lateral lengths (Figure 15). The earliest wells in this study drilled in 2010-2011 had lateral lengths typically less than 5,000 feet (1,524 meters) compared to more recent wells drilled from 2015-2018 and had lateral lengths extending over 9,000 feet (2,743 meters). Longer laterals led to an associated rise in the amount of fluid needed during hydraulic fracturing. This rise in fluid was not only caused by increased lateral length, but also by an overall increase in the average size of hydraulic fracturing jobs. Increased job size was observed as an increase in the amount of fluid pumped per 1,000 feet (305 meters) of lateral length (Figure 16). From 2010 to 2014, the average amount of fracturing fluid pumped was $\sim 25,000-30,000$ barrels per 1,000ft. (305 meters) (Figure 16). This average rate steadily increased over time across all five areas of the study to an average of $\sim 65,000$ barrels per 1,000 feet (305 meters) in 2018 . 


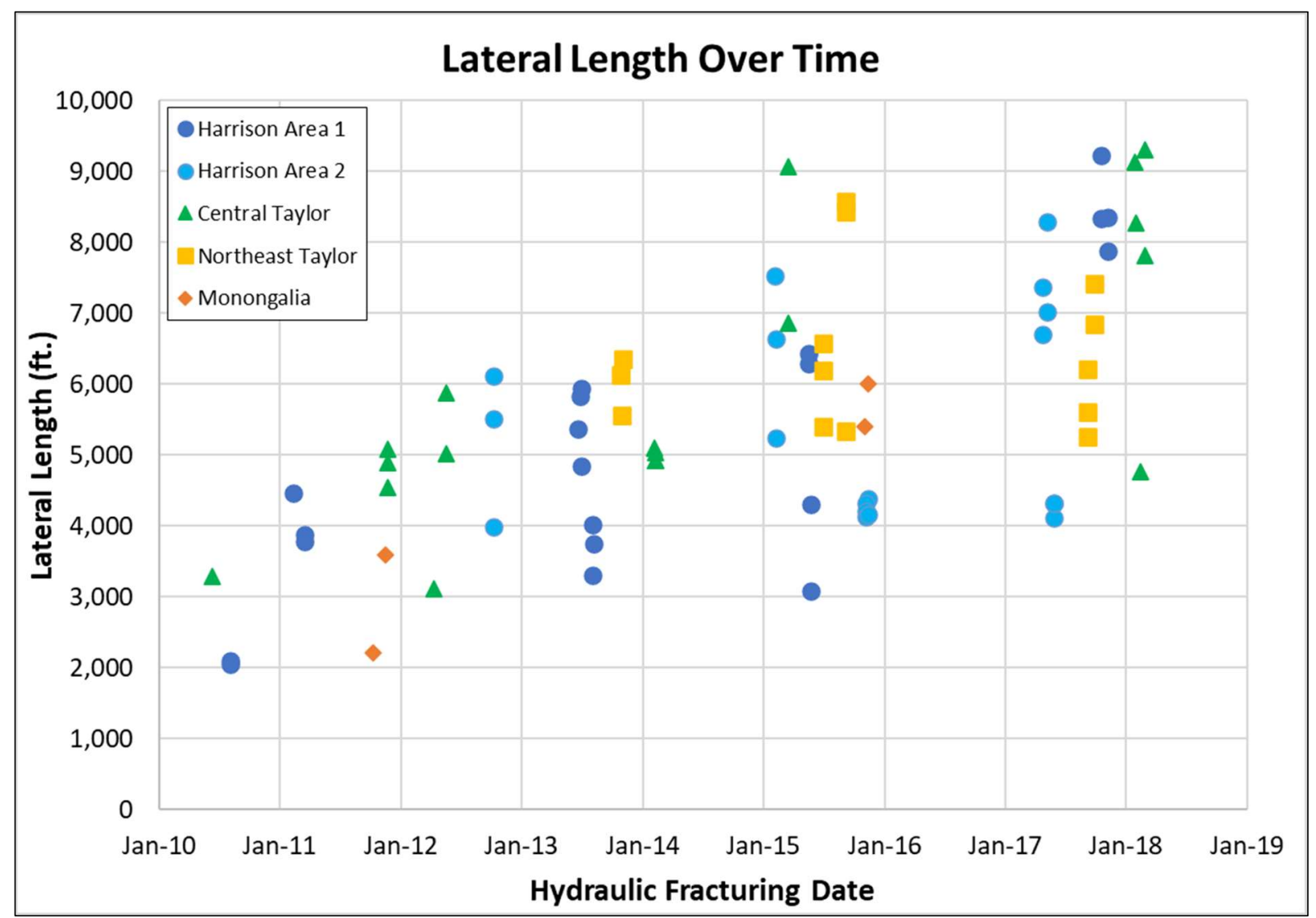

Figure 15 - As experience and technology have progressed, horizontal-well lateral lengths have gotten progressively longer across the study area. Early wells have lengths typically less than 5,000 feet (1,524 meters), while more recent wells have lateral length exceeding 9,000 feet (2,743 meters). Increasing lateral lengths can be seen in all five areas.

Such increases in pumped volume could affect volumes of fluid return. The percent fluid recovered for the five areas in this study indicated that recovered percentage in each area tended to fall within a certain range, plus the possibility of outliers based on outside factors. To determine if returned fluid percentages varied among the five areas, the mean values and total spreads were compared (Figure 17). Four of the five areas had at least 14 wells hydraulically fractured with increasing lateral lengths and fluid pumped, so the data captured these variations in well design. The only area suffering from lack of data is the Monongalia Area where only four wells were analyzed. However, the wells were drilled in sets of two, four years apart, so they still 


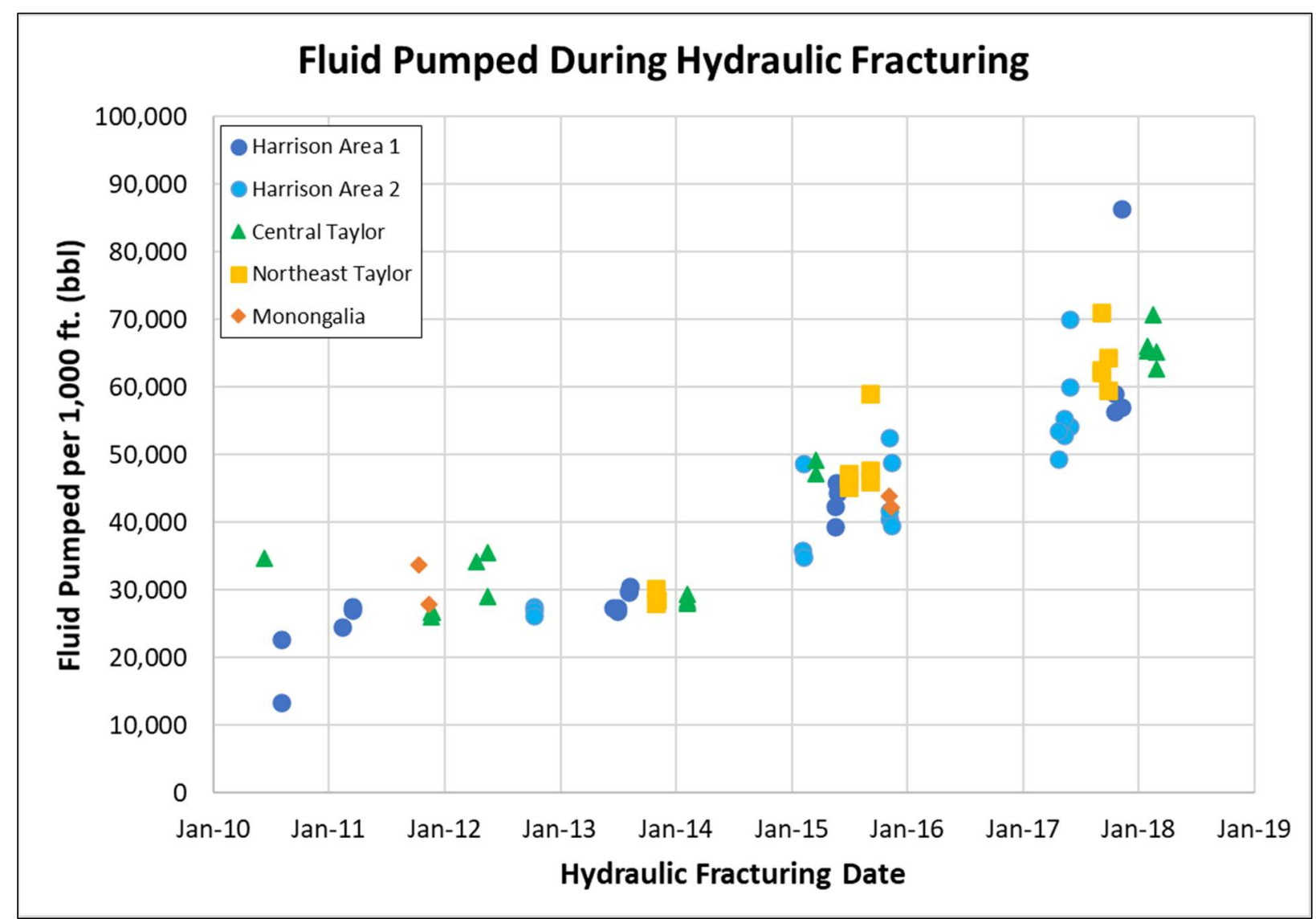

Figure 16 - As development progressed, the average hydraulic fracturing job increased in size. The amount of fluid pumped per 1,000 feet of lateral length has increased from 25,000 bbls per 1,000 feet in 2010 to 65,000 bbls per 1,000 feet in 2018 .

captured changes in well design. The overall mean trend showed that wells in the Harrison County areas generally returned a higher percentage of fluid than wells in the Taylor and Monongalia areas. Additionally, Central Taylor returned a higher percentage than Northeast Taylor and Northeast Taylor returned a higher percentage than Monongalia. This trend indicates that as development moves east, a lower percentage of fluid is returned. When comparing the two Harrison County areas, the data for Area 2 completely fit within the range of Area 1 . This indicates that fluid return behavior between these two areas was similar.

The 16 wells in Harrison Area 1 returned $\sim 13 \%$ to $\sim 39 \%$ of the injected fluid, one the largest spreads of return percentage of any area in this study (Appendix B, Figure B-1). The amount of 


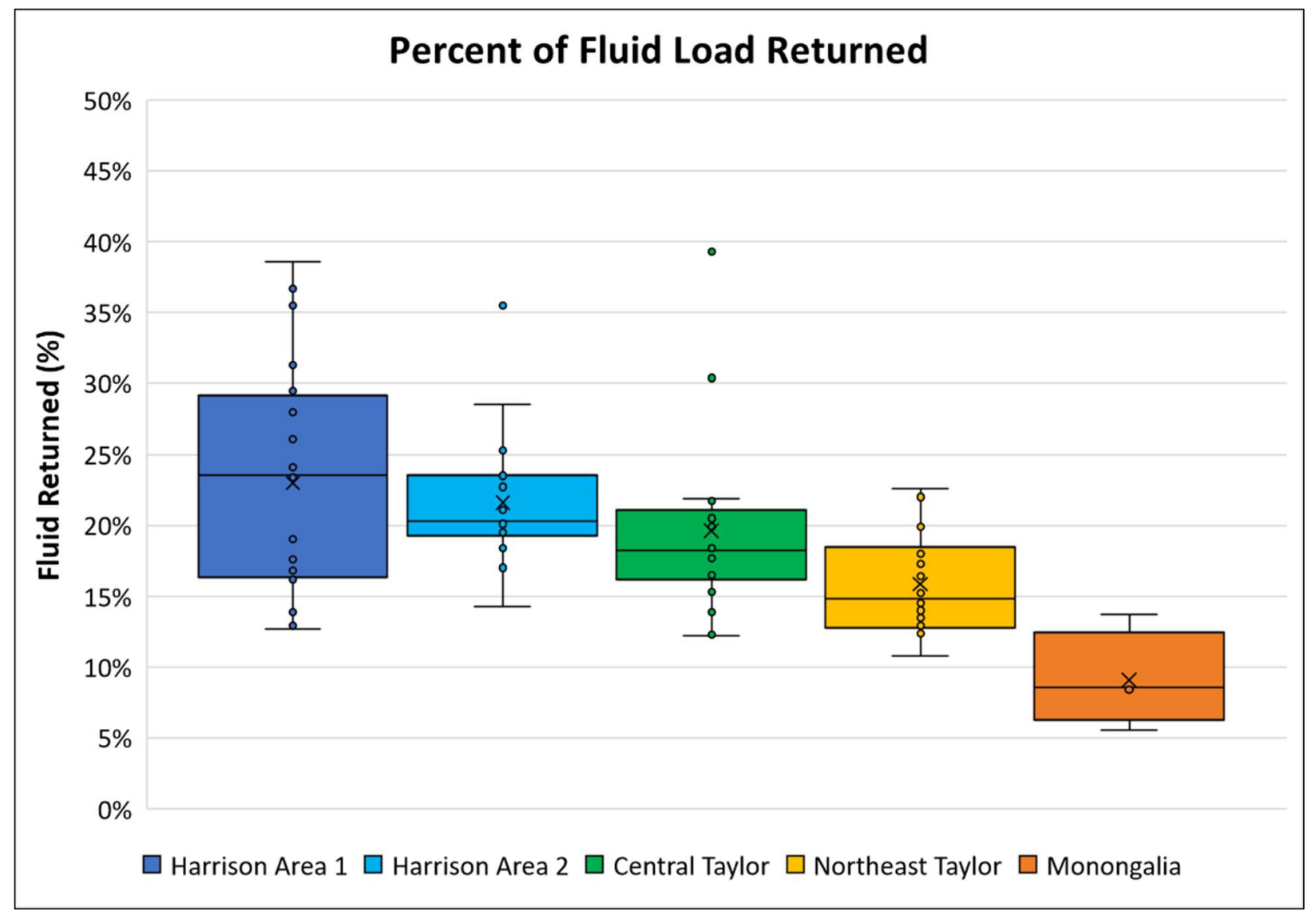

Figure 17 - Range of fluid returned percentages in the five areas in this study. Harrison Areas 1 \& 2 tend to return a higher percentage of fluid followed by Central Taylor, Northeast Taylor, and Monongalia. As of September 2020, no well has returned $>40 \%$ of the initial fluid load.

time these wells have been returning fluid ranges from $\sim 1,000$ days $(\sim 2.7$ years $)$ to $3,600+$ days ( $\sim 10$ years). The 7.3-year age difference between the oldest and youngest wells was the largest for the areas in this study. Differences in well age only accounted for a minor amount of difference in returned fluid. Higher volumes of fluid recovery typically occurred within the first 2 to 3 years, with lesser amounts returning over the life of the well. A more important variable affecting fluid return percentage was the aggressiveness of initial flowback. The oldest wells with the highest percentage of fluid returned tended to have much steeper slopes during initial return, indicating fluid returned much faster. Younger wells had a more gradual slope indicating more constrained initial flowback. At least six wells in this group showed a distinct rise in fluid 
production after 1,000 days ( 2.7 years) of fluid recovery. This was likely caused by three main scenarios. The first involved an adjustment to the flow dynamics where the gas flow rate was decreased resulting in an increase in well pressure enabling the well to carry more fluid to the surface after pressure is released. These new flow conditions caused a spike in fluid production followed by a leveling-off period. The second scenario involved the complete shut-in of the well for a period of time that resulted in a large increase in wellhead pressure. This scenario resulted in a sharp increase in fluid production that is not as high as initial fluid production, but appeared to have a steady, long lasting effect. The third scenario involved continued well development in the area. Hydraulic fracturing of offset wells changed the pressure dynamic of the reservoir and more fluid was pushed into neighboring wellbores. This fluid was not fracturing fluid from the well undergoing hydraulic fracturing, instead it was original hydraulic fracturing and formation fluid being pushed back into the original wells. One of these scenarios occurred in each of the wells displaying renewed increases of produced water in Harrison Area 1 (Arsenal Resources, personal communication).

Harrison Area 2 contains 18 wells and is located just south of Harrison Area 1. The wells in this area showed total returned fluid ranging from $\sim 14 \%$ to just over 35\% (Appendix B, Figure B-2). These wells have an age range of $\sim 1,100$ days (3.0 years) to $\sim 2,600$ days ( 7.1 years). In general, the wells in this area had similar early flowback patterns and remain clustered within a range of $\sim 10 \%$ with only three exceptions. These exceptions followed the same initial trends as the others but deviated due to changes in one of the production dynamics previously mentioned. The one well lagging behind the others in this area was not significantly different $(<10 \%)$ as there were 
some wells in Harrison County Area 1 that had similar recovered percentages $(<15 \%)$, so it was not out of the ordinary for the Harrison County areas.

The Central Taylor Area contains 18 wells and is located $\sim 11$ miles east of the Harrison County areas. The wells in this area had total fluid returns ranging from $\sim 12 \%$ to $\sim 40 \%$ and represented the largest spread in fluid return percentage among the study areas (Appendix B, Figure B-3). These wells had an age range of $\sim 900$ days ( 2.5 years) to $\sim 3,600$ days (10.0 years). The wells in this area clustered in a narrow range between $12 \%$ and $22 \%$, except for two wells that were much higher, and shared similar curve shapes. Within the cluster, three wells showed a change in fluid return behavior that were caused by the same scenarios discussed in Harrison areas 1 and 2 . The two wells that returned more fluid than the others started on a similar trajectory as the other wells but did not fall off at the same rate. These wells were particularly high producing, allowing for a more aggressive flowback program (Arsenal Resources, personal communication). In both wells, the produced-water curves have flattened, but are still returning fluid at slightly higher rates than the other wells in the area.

The Northeast Taylor Area contains 14 wells and is located $\sim 10$ miles northeast of the Central Taylor Area. The wells in this area returned total fluid ranging from $\sim 11 \%$ to $\sim 22 \%$ (Appendix B, Figure B-4). These wells had an age range of $\sim 1000$ days (2.7 years) to $\sim 2,300$ days (6.3 years) and fell into a similar range with no true outliers. A few wells returned a higher percentage than the others, but nothing on the scale of Central Taylor and Harrison County where a few wells in each area returned significantly more fluid than the rest. Like the other areas, there were a couple of wells whose behavior changed during production. This change in 
behavior coincided with the hydraulic fracturing of neighboring wells, which similar to wells seen in Harrison Area 1, suggested offset development influenced fluid return behavior.

The Monongalia Area contains 4 wells and is located $\sim 9$ miles north of the Northeast Taylor Area. The wells in this area returned total fluid ranging from $\sim 5.5 \%$ to $\sim 14 \%$ (Appendix B, Figure B-5). These wells had an age range of $\sim 1,700$ days (4.7 years) to $\sim 3,200$ days ( 8.8 years). The fluid return curves for the wells in this area were all similar with one well slightly higher than the rest. Percent fluid return in the Monongalia Area was significantly lower than the other areas in this study, which may be caused by the amount of time these wells have been shut in. Due to a limited gas market, seasonal curtailments for these wells were necessary. As of September 2020, one well had been shut-in a total of 735 days, and another shut-in 747 days. Shut-in times for the two newest wells were much lower at 94 days and 219 days. Interestingly, there was not a significant increase in returned fluid after the shut-in periods as observed in the other areas. This was likely caused by the highly restrictive flow rates the wells were subject to when turned back into production and limited fluid returned to the surface.

\section{Water Sample Analysis - Source water}

Analysis results of the source water used as makeup for hydraulic fracturing operations revealed low levels of TDS and major ions (Table 3). The TDS value for the West Fork River in Harrison County was $354 \mathrm{mg} / \mathrm{L}$, for the Tygart River in Taylor County the value was $369 \mathrm{mg} / \mathrm{L}$, and for the Monongahela River in Monongalia County, the TDS value was $300 \mathrm{mg} / \mathrm{L}$. When looking at the combination of fracture stimulation chemicals and fresh water from the West Fork and Tygart rivers, the TDS increased slightly but was still $<2,000 \mathrm{mg} / \mathrm{L}$ (TDS is $1,466 \mathrm{mg} / \mathrm{L}$ per sum of dissolved constituents or TDSsdc). There was significantly higher TDS $(7,928 \mathrm{mg} / \mathrm{L})$ in the 
mixed-source makeup sample using a mixture of freshwater and produced water obtained from existing Marcellus wells in Harrison and Taylor counties. This was 20x the TDS of freshwater, but still well below TDS values of produced water. Produced water made up 3 - 5\% of the total volume of water used for hydraulic fracturing in Harrison and Taylor counties (Arsenal Resources, personal communication).

\begin{tabular}{|c|c|c|c|c|c|c|c|c|c|c|c|c|c|c|c|}
\hline \multirow[b]{2}{*}{ Source } & \multirow[b]{2}{*}{ Source Area } & \multirow[b]{2}{*}{ Sample Date } & \multirow[b]{2}{*}{$\mathrm{pH}$} & \multirow[b]{2}{*}{$\begin{array}{c}\mathrm{TDS}^{1} \\
(\mathrm{mg} / \mathrm{L}) \\
\end{array}$} & \multicolumn{7}{|c|}{ CATIONS } & \multicolumn{3}{|c|}{ ANIONS } & \multirow[b]{2}{*}{$\begin{array}{l}\text { Charge } \\
\text { Balance } \\
\end{array}$} \\
\hline & & & & & $\begin{array}{c}\mathrm{Ba} \\
(\mathrm{mg} / \mathrm{L}) \\
\end{array}$ & $\begin{array}{c}\mathrm{Ca} \\
(\mathrm{mg} / \mathrm{L})\end{array}$ & $\begin{array}{c}\mathrm{Fe} \\
(\mathrm{mg} / \mathrm{L})\end{array}$ & $\begin{array}{c}\mathrm{Mg} \\
(\mathrm{mg} / \mathrm{L})\end{array}$ & $\begin{array}{c}\mathrm{K} \\
(\mathrm{mg} / \mathrm{L}) \\
\end{array}$ & $\begin{array}{c}\mathrm{Na} \\
(\mathrm{mg} / \mathrm{L}) \\
\end{array}$ & $\begin{array}{c}\mathrm{Sr} \\
(\mathrm{mg} / \mathrm{L})\end{array}$ & $\begin{array}{c}\mathrm{Cl} \\
(\mathrm{mg} / \mathrm{L}) \\
\end{array}$ & $\begin{array}{r}\mathrm{HCO} 3 \\
(\mathrm{mg} / \mathrm{L}) \\
\end{array}$ & $\begin{array}{c}\mathrm{SO} 4 \\
(\mathrm{mg} / \mathrm{L}) \\
\end{array}$ & \\
\hline West Fork River & Harrison Co. & $1 / 15 / 2019$ & 7.85 & 354 & 0 & 56 & 0.1 & 9 & 0 & 49 & 0 & 125 & 51 & 63 & $-0.03 \%$ \\
\hline Tygart River & Taylor Co. & $1 / 15 / 2019$ & 7.78 & 369 & 0 & 52 & 0.2 & 27 & 0 & 36 & 0 & 175 & 51 & 28 & $0.27 \%$ \\
\hline Monongahela River & Monongalia Co. & $11 / 11 / 2015$ & N/A & $300^{2}$ & 0.12 & 26 & 0.8 & 10 & 4 & 34 & 0.38 & 51 & $\mathrm{~N} / \mathrm{A}$ & 132.1 & $-4.31 \%$ \\
\hline $\begin{array}{c}\text { West Fork, Tygart \& } \\
\text { Produced Water }\end{array}$ & $\begin{array}{c}\text { Harrison \& } \\
\text { Taylor }\end{array}$ & $1 / 15 / 2019$ & 5.36 & 7928 & $230^{3}$ & 757 & 0.2 & 139 & 0 & 1926 & $0^{3}$ & 4799 & 77 & 0 & $-0.10 \%$ \\
\hline $\begin{array}{l}\text { Frac Fluid \& } \\
\text { Fresh Water }\end{array}$ & $\begin{array}{c}\text { Harrison \& } \\
\text { Taylor }\end{array}$ & $1 / 15 / 2019$ & N/A & $<2000$ & 46 & 193 & $\mathrm{~N} / \mathrm{A}$ & 49 & $\mathrm{~N} / \mathrm{A}$ & $\mathrm{N} / \mathrm{A}$ & $\mathrm{N} / \mathrm{A}$ & 1100 & 56 & 22 & $-38.66 \%$ \\
\hline $\begin{array}{l}{ }^{1}=\text { TDS value calculat } \\
{ }^{2}=\text { value from Phan } \\
{ }^{3}=\text { Barium and Stron }\end{array}$ & $\begin{array}{l}\text { ted } \\
\text { et al., } 2020 \\
\text { tium value was }\end{array}$ & bined in & & & & & & & & & & & & & \\
\hline
\end{tabular}

Table 3-Concentration of TDS and major ions in source waters used for hydraulical fracturing across the study area.

Ions tested for in the source water include $\mathrm{Ba}, \mathrm{Ca}, \mathrm{Fe}, \mathrm{Mg}, \mathrm{K}, \mathrm{Na}, \mathrm{Sr}, \mathrm{Cl}, \mathrm{HCO}_{3}$, and $\mathrm{SO}_{4}$. Concentrations of each of these ions remained low in the fresh waters sourced from the West Fork, Tygart, and Monongahela rivers (Table 3). The West Fork River had the highest concentration of $\mathrm{Ca}$ and $\mathrm{Na}$. The Tygart River had the highest concentration of $\mathrm{Mg}$ and $\mathrm{Cl}$. The Monongahela River had the highest concentration of $\mathrm{Ba}, \mathrm{Fe}, \mathrm{K}, \mathrm{Sr}$, and $\mathrm{SO}_{4} . \mathrm{HCO}_{3}$ was highest in both the West Fork and Tygart rivers, a value was not reported for the Monongahela River sample. There was a significant difference in $\mathrm{Cl}$ values among the West Fork, Tygart, and Monongahela samples, with West Fork and Tygart values 2.5x and 3.5x times higher than Monongahela values respectively. This difference in $\mathrm{Cl}$ levels may have resulted from the timing of the samples. The West Fork and Tygart samples were obtained in January, which in northern West Virginia, can be a particularly snowy period requiring varying amounts of road salt whose 
runoff can affect local chloride levels. The Monongahela River sample were taken in November, typically prior to road salt application.

Major ion concentrations see a minimal rise when combined with the chemicals used in the hydraulic fracturing fluid. However, a large difference was observed in the ion concentrations of the mixture of fresh water from the West Fork and Tygart rivers combined with produced water from nearby Marcellus wells. There was a significant increase in $\mathrm{Ba} / \mathrm{Sr}$ (reported together), $\mathrm{Ca}$, $\mathrm{Mg}, \mathrm{Na}, \mathrm{Cl}$, and $\mathrm{HCO}_{3}$. $\mathrm{SO}_{4}$ was lower in the mixed sample possibly due to dilution or the sample contained a concentration below the detection limit. Fe and $\mathrm{K}$ were relatively unchanged. The charge balance for these water samples was good, except the sample containing frac fluid and freshwater. Multiple cations were not tested in this sample, which could explain the large negative variance. Overall, the ion concentrations observed in source water samples were minor when compared to the concentrations in the produced water samples.

\section{Water Sample Analysis - Produced water}

For this study, produced water was defined as water produced by a well after it was hooked up to its final production equipment and all flowback equipment removed. Produced-water chemistry is an important piece of information to determine the interaction between the Marcellus formation and hydraulic fracturing fluid as wells age. Many studies (Blauch et al., 2009, Haluszczak et al., 2013, Engle and Rowan, 2014, Rowan et al., 2015, among others) have observed produced water behavior within the first few years of a wells production history. For this study, the 202 produced-water sample analyses spanned from samples taken within the first few months to samples taken after ten years of production. Samples were tested for TDS, $\mathrm{Ba}, \mathrm{Ca}$, 
$\mathrm{Mg}, \mathrm{Mn}, \mathrm{Fe}, \mathrm{K}, \mathrm{Na}, \mathrm{Sr}, \mathrm{Cl}, \mathrm{HCO}_{3}$ and $\mathrm{SO}_{4}$. The concentrations of $\mathrm{Mn}, \mathrm{HCO}_{3}$, and $\mathrm{SO}_{4}$ were typically low to non-detectable and were not considered individually.

\section{Charge Balance}

Charge balancing was performed on the produced water sample results to verify their validity. Charge balance was calculated using the equation:

$$
\text { Charge Balance }(\%)=\frac{\Sigma m_{i} * z_{i}}{\Sigma m_{i} * z_{i} \mid} \text {, }
$$

where $m_{i}$ is the molal concentration of ion $i$ and $z_{i}$ is the charge of ion $i$ (Dresel and Rose, 2010). In general, charge balance was good, 115 of 202 samples $(56.9 \%)$ had a charge balance of $\pm 5 \%$. Expanding further, 171 of 202 samples (84.7\%) had a charge balance of $\pm 10 \%$, and 189 of 202 samples $(93.6 \%)$ had a charge balance of $\pm 20 \%$ (Figure 18 ).

Ions of sodium, calcium, and chloride were the largest cation and anion contributors to the charge balance, so any errors involving those ions would have a sizable impact on the results. Barium, strontium, and magnesium had the next largest effect on charge balance. Potassium was a minor component and not tested in multiple samples. The lack of potassium values did not have a large effect on the overall charge balance due to its generally low concentration as seen in other samples. Additionally, in most samples, sulfate was below the minimum detection limit, and assumed to be zero. This was a valid assumption as the minimum detection limit was low enough that any quantity below that value would have a negligible effect on the overall charge balance. 
Across the study area, charge balances tended to skew negative indicating there are more minor cations not represented in the analyses than minor anions (Figure 18). The Harrison areas were most negative followed by Central Taylor and Northeast Taylor. The lone exception was the Monongalia Area which was positively skewed. The complete distribution of charge balances is shown in Figure 18 with a red box indicating the $\pm 10 \%$ charge balance range. Excluding outliers, each area, except for Harrison Area 1, nearly fit within this $\pm 10 \%$ range indicating acceptable charge balances.

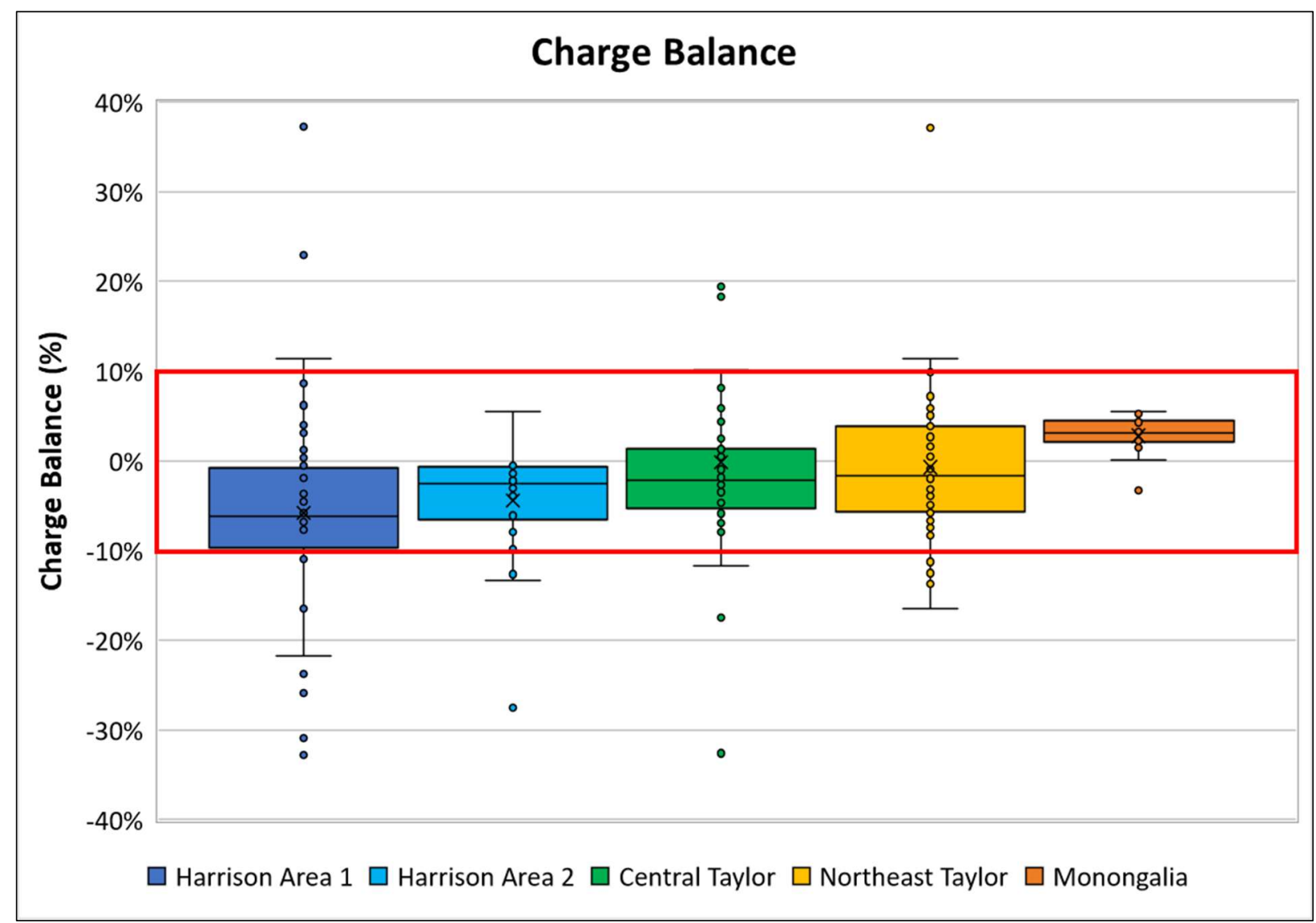

Figure 18 - Charge balance for each of the five area across the study area. Harrison Area 1 shows the largest range of balancing error followed by Northeast Taylor, Central Taylor, Harrison Area 2, and Monongalia. The red box indicates $+1-10 \%$ charge balance range. Most samples fall within or just outside the $+/-10 \%$ charge balance range. 


\section{$\underline{T D S}$ and Ionic Concentrations}

Produced water samples were tested for TDS and ions of $\mathrm{Ba}, \mathrm{Ca}, \mathrm{Mg}, \mathrm{Mn}, \mathrm{Fe}, \mathrm{K}, \mathrm{Na}, \mathrm{Sr}, \mathrm{Cl}$, $\mathrm{HCO}_{3}$ and $\mathrm{SO}_{4}$. A comparison of TDS against the sum of ions showed a good correlation indicating that these ions are make up nearly the entire TDS volume in the samples and no major constituents were excluded (Figure 19). A few samples plotted well above the line indicating more ions present than TDS, but most samples fell on the unit-slope line or very close. Harrison areas 1 and 2 values intermixed in the middle to upper ranges of the plot suggesting similar behavior. The Central Taylor, Northeast Taylor, and Monongalia areas intermixed in the middle to lower ranges of the plot, indicating those three areas share similar behaviors.

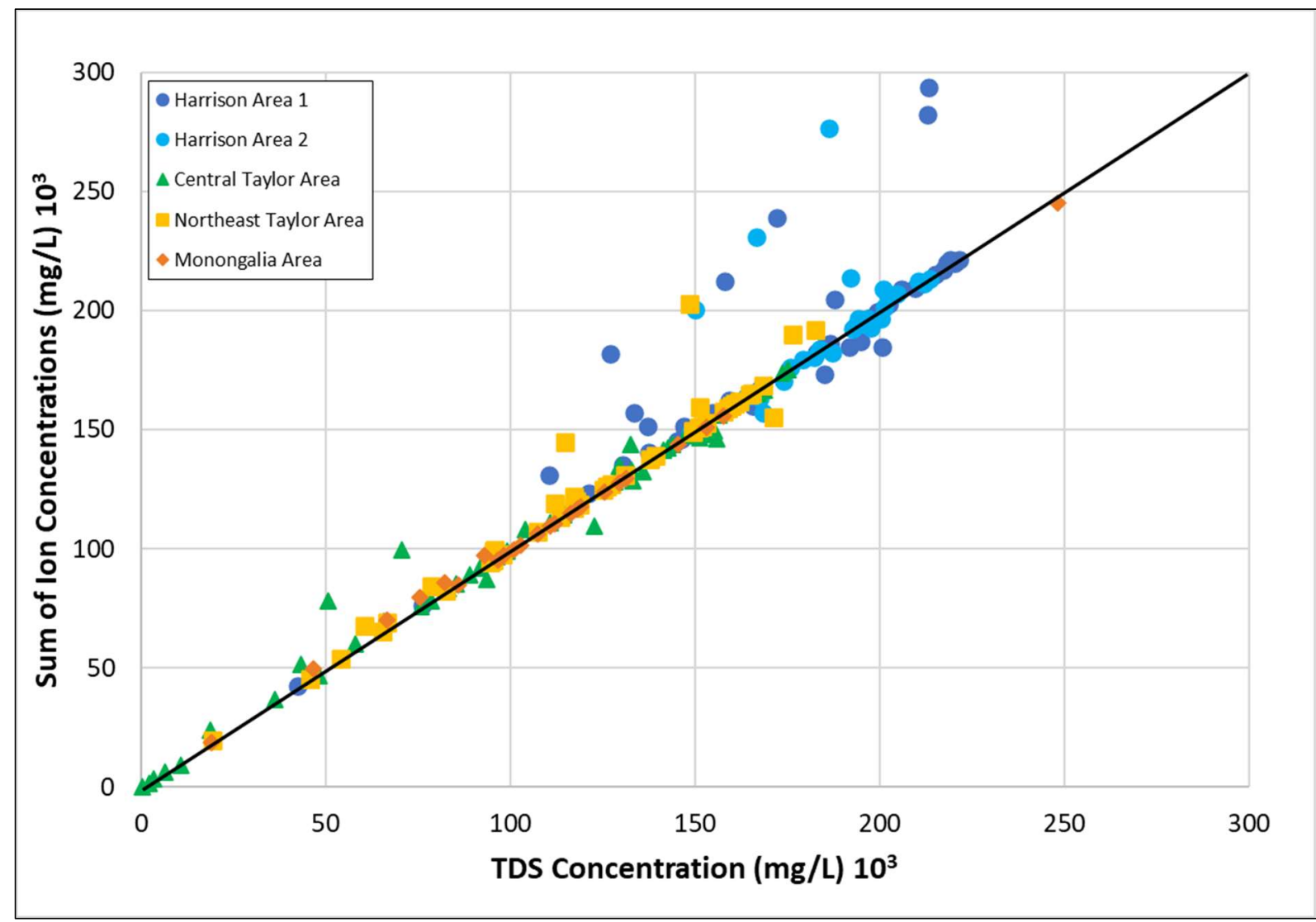

Figure 19-Plot of the sum of ion concentrations against TDS concentrations for the produced water samples from the five areas across the study area. Harrison areas 1 and 2 plot in the middle to upper ranges. Central Taylor, Northeast Taylor, and Monongalia areas plot in the middle to lower ranges. 
TDS concentrations for each sample was grouped by area and displayed in a box and whisker plot (Figure 20). The plot shows that TDS values tended to be highest in Harrison County where Harrison Area 2 had a mean TDS value of 186,063 mg/L and Harrison Area 1 had a mean TDS value of $168,959 \mathrm{mg} / \mathrm{L}$. Northeast Taylor had the third highest mean TDS value $(122,403 \mathrm{mg} / \mathrm{L})$ followed by Monongalia $(110,034 \mathrm{mg} / \mathrm{L})$ and Central Taylor $(103,739 \mathrm{mg} / \mathrm{L})$. The values for Northeast Taylor were slightly higher than those for Monongalia and Central Taylor, but much lower than the two Harrison Areas. There was a distinct difference among the areas with the Harrison areas mean TDS values $>165,000 \mathrm{mg} / \mathrm{L}$ and the other three areas mean TDS values $<123,000 \mathrm{mg} / \mathrm{L}$.

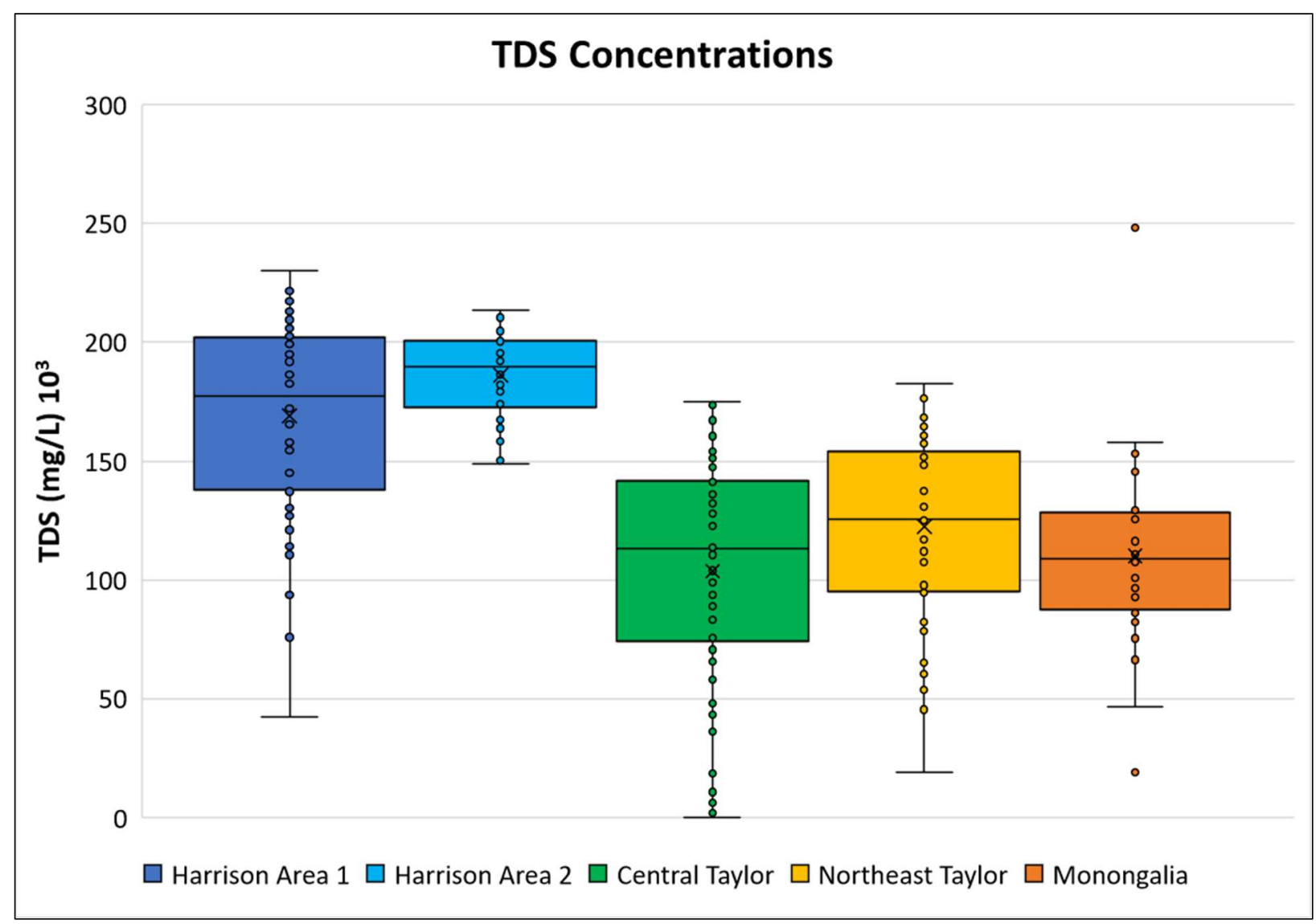

Figure 20 - Box and whisker plot of TDS concentrations across the five areas of the study. Harrison areas 1 and 2 show similar values that are distinctively higher than the Central Taylor, Northeast Taylor, and Monongalia areas, which show similar values. 
Individually, chloride had the highest concentrations in each of the studies areas and was by far the highest anion with $\mathrm{HCO}_{3}$ second highest. In nearly every sample, $\mathrm{SO}_{4}$ was below the minimum detection limit and considered to be zero. Cation concentrations were the highest for $\mathrm{Na}$ followed by $\mathrm{Ca}, \mathrm{Ba}, \mathrm{Sr}, \mathrm{Mg}, \mathrm{K}, \mathrm{Fe}$, and $\mathrm{Mn}$. Box and whisker concentrations plots for each ion except, $\mathrm{Mn}, \mathrm{HCO}_{3}$ and $\mathrm{SO}_{4}$, are in Appendix C. Mean ionic concentrations for $\mathrm{Ca}, \mathrm{K}, \mathrm{Mg}$, $\mathrm{Na}, \mathrm{Sr}$, and $\mathrm{Cl}$ were highest in Harrison areas 1 and 2 with mean values that are relatively close, indicating similar rock characteristics and interactions with hydraulic fracturing fluid. Mean Ba concentrations are highest in Northeast Taylor but only slightly higher than Monongalia and Central Taylor. All three those area had mean Ba values noticeably higher than both Harrison areas. Additionally, Central Taylor, Northeast Taylor, and Monongalia had relatively similar mean values for $\mathrm{Ca}, \mathrm{K}, \mathrm{Mg}, \mathrm{Na}, \mathrm{Sr}$, and $\mathrm{Cl}$, with Northeast Taylor typically having the highest. This indicated similar rock characteristics and rock-fluid interactions among those three areas. Only mean iron concentrations were similar among all five areas. Monongalia had the highest mean concentration that was $\sim 100 \mathrm{mg} / \mathrm{L}$ higher than Northeast Taylor, the lowest mean concentration. Overall, ionic concentrations indicated that produced water from Harrison Area 1 and Harrison Area 2 were ionically similar and produced water from Central Taylor, Northeast Taylor and Monongalia were ionically similar (Figure 21). All produced water sample analysis results are in Appendix D.

\section{$\underline{\text { Ion Concentrations as Percentage of TDS }}$}

Ionic concentration results of the 202 produced water samples indicated distinct differences in produced water among the five areas. Harrison areas 1 and 2 typically had higher TDS concentrations and showed similar trends in ionic concentrations, whereas Central Taylor, 

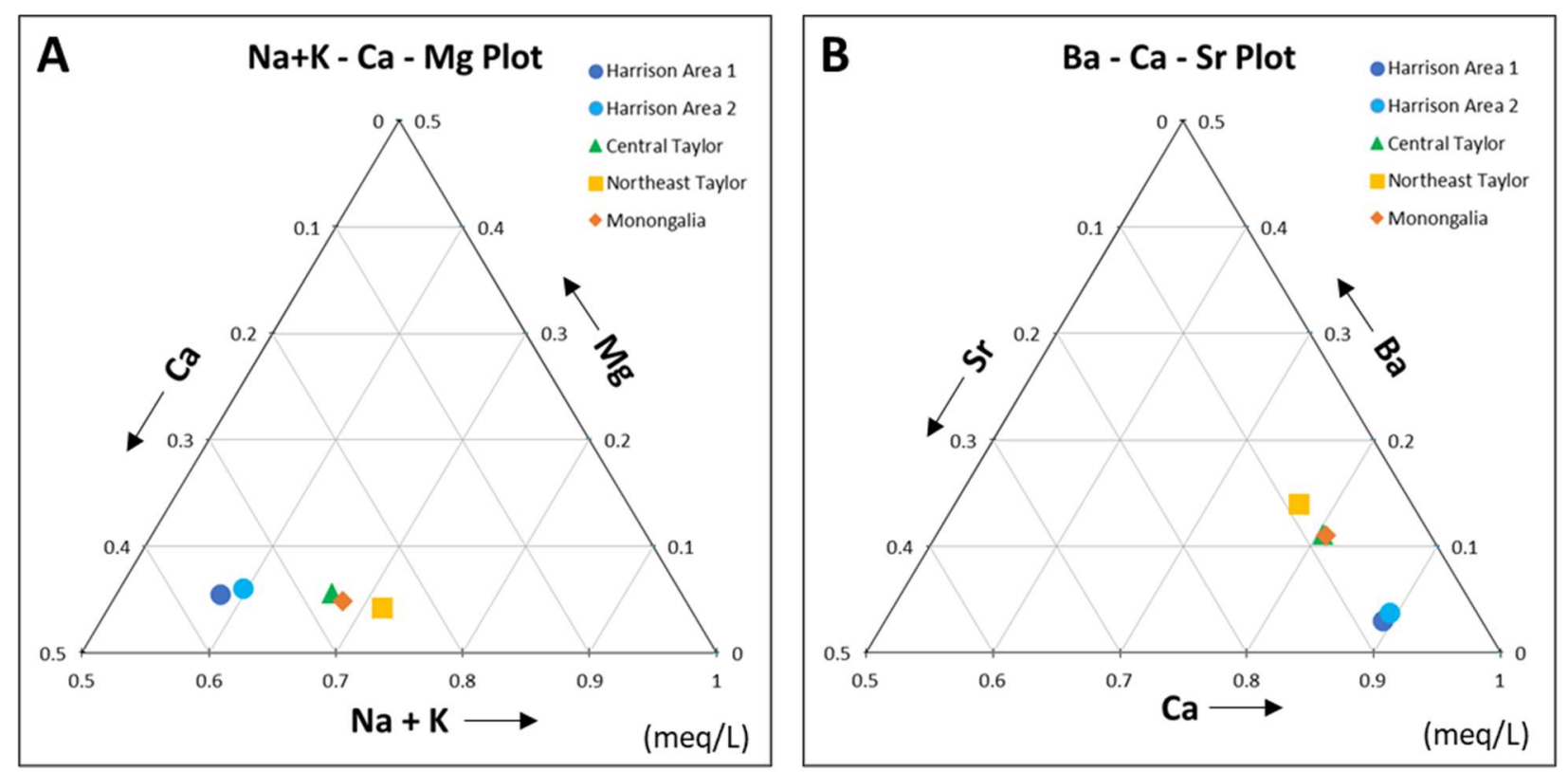

Figure 21 - Ternary plot of mean equivalent ratios of cations from produced water samples. A.) Mean ratios of $\mathrm{Na}, \mathrm{K}, \mathrm{Ca}$, and $\mathrm{Mg}$ indicate that produced waters in Harrison areas 1 and 2 are ionically similar, but vary from Central Taylor, Northeast Taylor, and Monongalia, which are ionically similar. Note that the Ca and $\mathrm{Mg}$ scales are truncated at 50\% B.) Mean ratios of Ba, $\mathrm{Ca}$, and Sr also indicate similarities between Harrison areas 1 and 2, but differ from Central Taylor, Northeast Taylor, and Monongalia, which are ionically similar. However, Northeast Taylor does show slightly more Ba and less Ca than Central Taylor and Monongalia. Note that the Ba and Sr scales are truncated at 50\%.

Northeast Taylor, and Monongalia areas showed similar ionic concentrations, but at lower concentrations than the Harrison areas, apart from $\mathrm{Ba}$. With the highest TDS values in the Harrison areas, it is not unexpected that those areas had the highest concentrations of the other ionic constituents (except $\mathrm{Ba}$ ). To correct for this difference, proportional ionic concentrations were determined and compared for $\mathrm{Ba}, \mathrm{Sr}, \mathrm{Ca}, \mathrm{Na}$, and $\mathrm{Cl}$. Other minor ions such as $\mathrm{K}, \mathrm{Fe}, \mathrm{Mn}$, $\mathrm{HCO}_{3}$ and $\mathrm{SO}_{4}$ were combined into one category named "Other".

When comparing the proportionality of ion distribution to concentrations, some new observations were evident. Overall, chlorides accounted for most of the anions in all areas and accounted for slightly more of the total TDS in Harrison Area $1(63.5 \%)$ and Harrison Area 2 
(63.1\%) than in Central Taylor (59.2\%), Northeast Taylor (59.5\%), and Monongalia (58.4\%)

(Figure 22). Sodium was the second-highest percentage in all five areas. Sodium concentrations (Appendix C, Figure C-6) showed higher levels in Harrison areas 1 and 2 than the other three areas, but when considered as a percent of total TDS, sodium made up a larger percentage in Monongalia (26.1\%), Northeast Taylor (25.5\%), and Central Taylor (23.1\%) than in Harrison Area 1 (20.9\%) and Harrison Area 2 (21.3\%). Calcium was the third-highest ion and made up a larger percentage in Harrison Area 1 (11.2\%) and Harrison Area 2 (11.0\%), than in Central Taylor (8.2\%), Northeast Taylor (7.5\%) and Monongalia (8.4\%). Similar to its concentration, barium made up a larger percentage in Northeast Taylor (4.6\%), Central Taylor (3.9\%), and Monongalia (3.9\%) than in Harrison Area 1 (1.2\%) and Harrison Area 2 (1.5\%). When considering magnesium and strontium, both concentrations were slightly higher in Harrison areas 1 and 2, but when considered as a percentage of total TDS, both make up roughly the same percentage across all areas. Magnesium proportion ranged from $0.7 \%$ to $1.2 \%$ and strontium ranges from $1.8 \%$ to $1.9 \%$. One particular result of note was the slightly elevated "Other" category proportion in Central Taylor $(2.8 \%)$ versus the other four areas $(0.1 \%$ to $0.5 \%)$. Several samples in Central Taylor had elevated iron concentrations relative to the rest of the samples. This was primarily observed in a few of the oldest, low-fluid producing wells in Central Taylor and likely the result of operational procedures as opposed to geochemical reactions, although precipitation of dissolved iron from pyrite cannot be completely ruled out. When considering ion concentrations as a percentage of TDS, it was again evident that Harrison areas 1 and 2 shared similar traits that differ from Central Taylor, Northeast Taylor, and Monongalia, which shared similar traits. 

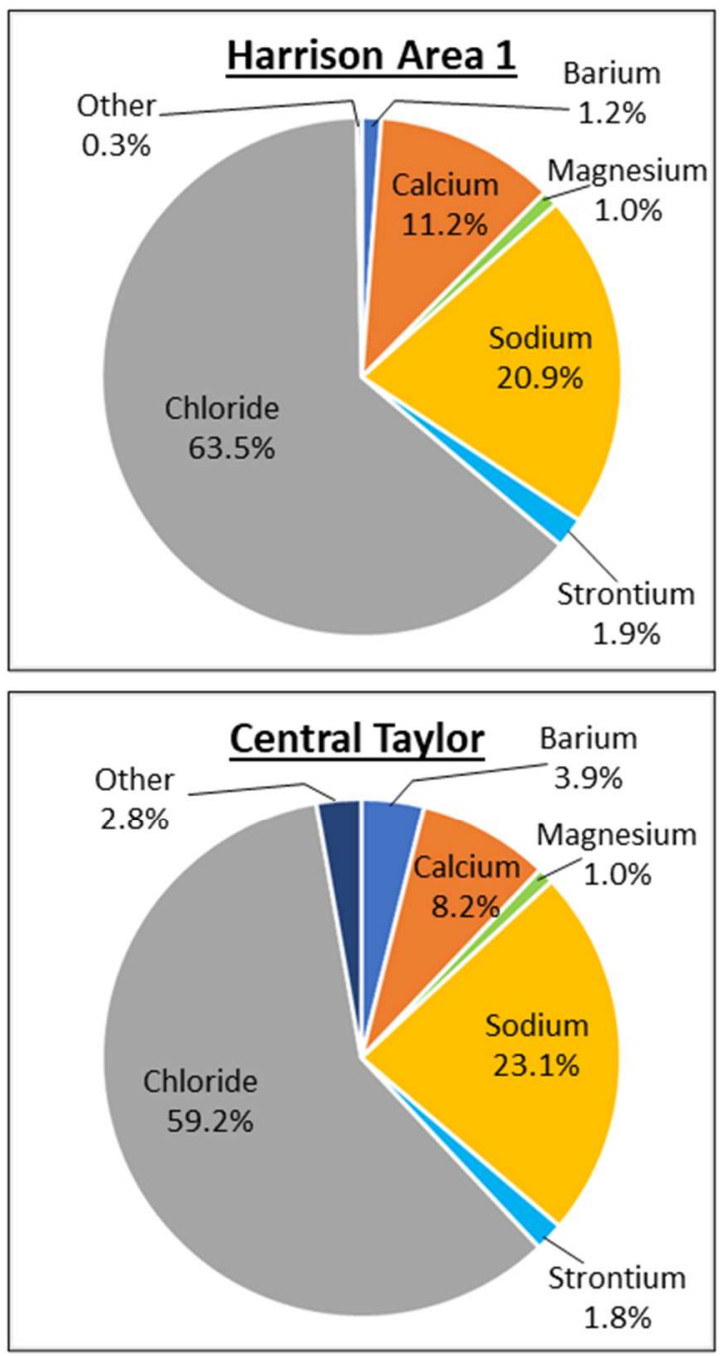
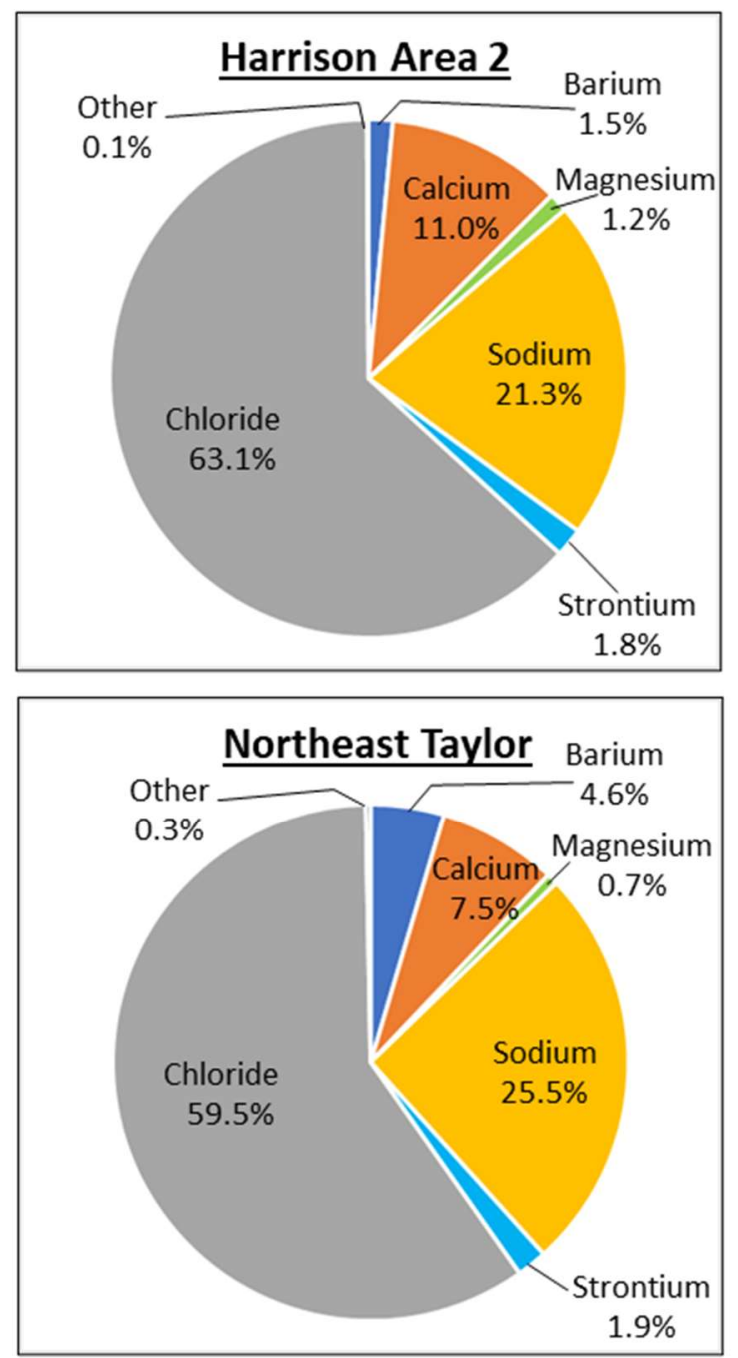

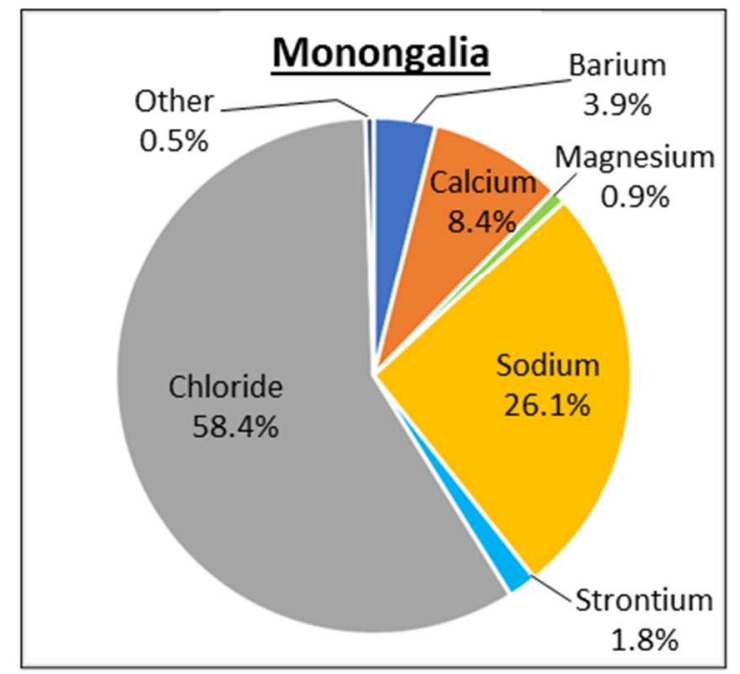

Figure 22-Mean proportional concentrations of ionic constituents of all produced water samples across the five areas in this study. Similar distributions exist between Harrison areas 1 and 2, but differ from Central Taylor, Northeast Taylor, and Monongalia, which share similar proportions. 


\section{Ion Behavior Over Time}

One important feature of this study was the time period over which samples were obtained. As previously mention, with few exceptions (e.g. Ziemkiewicz, 2017) most studies focused on the first few months or years of a well's lifespan. Some wells in this study had produced water samples taken within the first two years of production giving a picture of produced water characteristics in the early life cycle of the well, and subsequently sampled later in the life cycle ( 5 - 10 years) giving a window into produced water variations during the mid-life cycle of the well. In this section, proportional concentrations over time and total concentrations over time were considered to determine if the long term changes in produced water are similar to the extrapolated prediction made from early studies, or if extended sampling indicated dynamic behavior over the lifespan of Marcellus wells.

Of the 74 wells in this study, twelve wells were sampled at least five times over their existing lifespan, with another seven wells tested four time over their lifespan (Table 4). Examining the wells with the highest number of samples provided the best insight into variations over time.

Looking at one of the oldest wells from the Central Taylor Area showed that ionic proportions were relatively consistent over time (Figure 23). The biggest change in proportion occurred

\begin{tabular}{|l|c|c|c|c|c|}
\hline & $\begin{array}{c}\text { Harrison } \\
\text { Area 1 }\end{array}$ & $\begin{array}{c}\text { Harrison } \\
\text { Area 2 }\end{array}$ & $\begin{array}{c}\text { Central } \\
\text { Taylor Area }\end{array}$ & $\begin{array}{c}\text { Northeastern } \\
\text { Taylor Area }\end{array}$ & $\begin{array}{c}\text { Monongalia } \\
\text { Area }\end{array}$ \\
\hline Number of Wells & 20 & 18 & 18 & 14 & 4 \\
\hline Oldest Well (Years) & 10.1 & 7.9 & 10.2 & 6.9 & 8.9 \\
\hline Youngest Well (Years) & 2.8 & 3.2 & 2.5 & 2.9 & 4.8 \\
\hline Total \# Produced Water Samples & 48 & 30 & 54 & 46 & 24 \\
\hline \# Wells with 5+ samples & 0 & 3 & 5 & 3 & 2 \\
\hline \# Wells with 4 samples & 4 & 0 & 2 & 0 & 0 \\
\hline \# Wells with 3 samples & 8 & 0 & 4 & 10 & 0 \\
\hline \# Wells with 2 samples & 0 & 0 & 2 & 1 & 0 \\
\hline \# Wells with 1 sample & 8 & 15 & 5 & 0 & 0 \\
\hline
\end{tabular}

Table 4-Number of produced water samples taken per well across the five areas in this study. Age range and total number of samples taken in area is also shown. 
between the first and second sample taken at 390 days and 452 days after flowback began. After the sample taken at 452 days, the relative proportions stabilized and remained in a relatively tight range. Across all five areas, most wells with multiple samples exhibited similar behavior. In some instances, a single sample strayed from this trend, but typically fell back to the expected range in the subsequent sample. Evidence from these produced water samples suggested that typically, during Year 2 of production, ionic proportions stabilize and remain in a small range moving forward. Ziemkiewicz (2017) noted this behavior while observing produced water associated with the wells in the MSEEL study in the Monongalia Area. Those wells were $\sim 5$ years old at that time. The data presented in this section confirmed those observations and extended them into the other areas of this study, and extended them over time, up to 10 years for some wells.

The previously discussed data illustrated that ionic proportions of produced water stayed within a small range after the first 1 to 2 years of production. However, ion concentrations exhibited variations during a well's life cycle as well as varying behaviors across the five areas in this study. Initially all five areas followed the expected behavior that TDS concentrations, along with the various ions, increased during the first couple years following hydraulic fracturing. This was indicated by the low TDS and ion concentrations found in the source water compared to the high concentrations seen in produced water samples over time. Typically, between year one and year two, the wells began displaying varying behaviors regarding TDS concentrations.

Harrison Area 1 showed the most varied TDS behaviors over time. Four wells with four or more samples, and one well with three samples were plotted over time (Figure 24). Two wells showed 

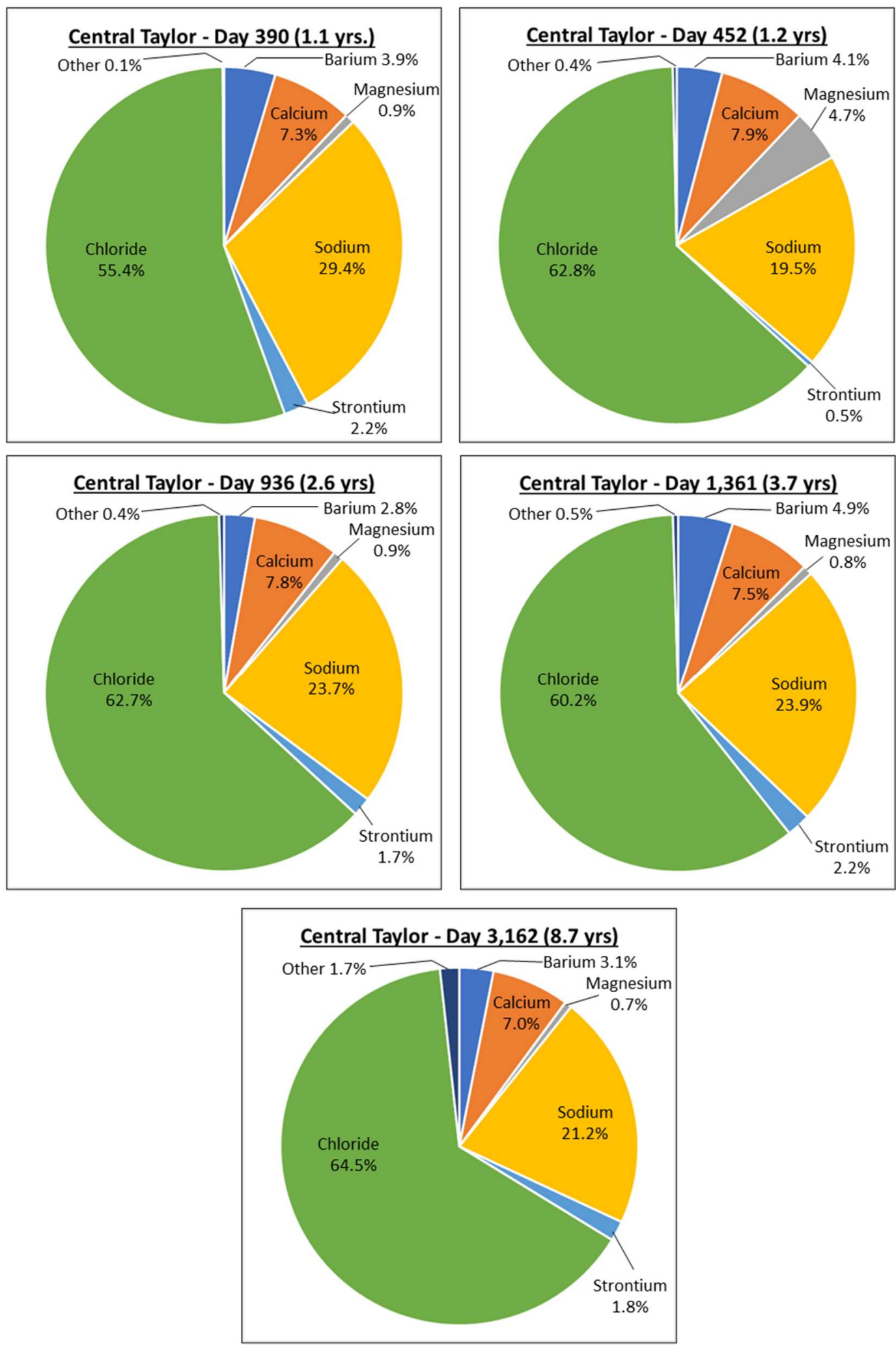

Figure 23 - Proportion of ionic concentrations from one of the oldest wells in the Central Taylor Area. Pie chart show that during the second year of production, ionic proportions stabilize and remain within a small range over the life of the well. For this well, ionic proportions observed on Day 452 are similar to proportions seen on Days 936, 1,361, and 3,162. 
a continuous decline in TDS concentrations over time. One well showed a general decline with the third sample, taken near Day 1,100, higher than the previous two samples, followed by another decrease. One well showed a general increase over time, with the third sample near Day 1,100 lower than the rest. One well had four samples that alternated higher and lower with a general increase in TDS concentrations. The remaining wells with multiple samples displayed a variety of these behaviors with some generally increasing TDS concentrations over time and others decreasing over time. In the previous section, it was discussed that ionic proportions stayed relatively similar over time. While this remains true, some wells in Harrison Area 1 showed increases in iron, strontium, and barium concentrations over time. These increases were modest when considered at the ion level, however, when considered at the total TDS level, the increases were not large enough to significantly alter the relative proportions of the ions.

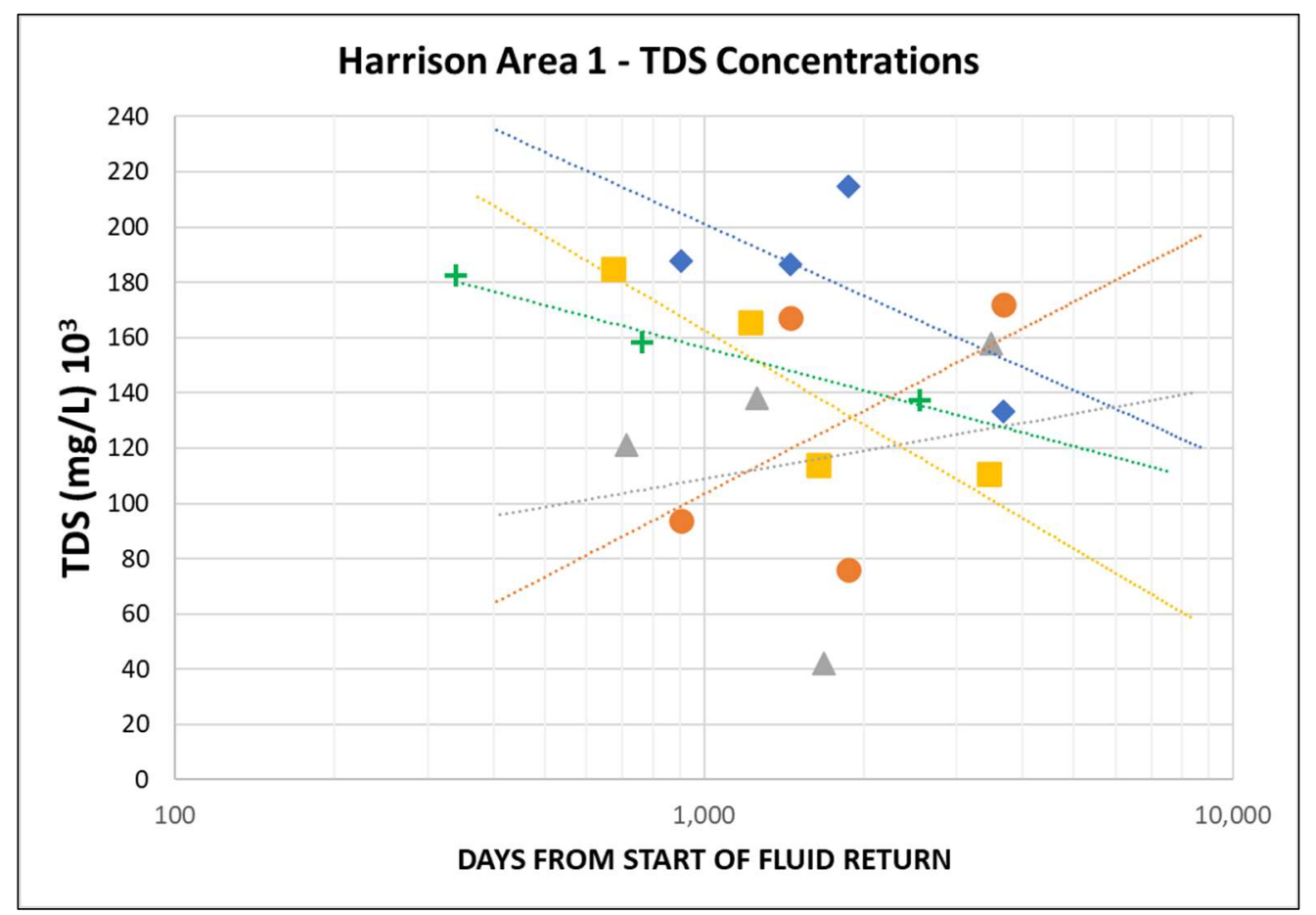

Figure 24-TDS concentrations for five wells in Harrison Area 1 with four samples and one well with three samples. TDS concentrations indicate multiple behaviors over time including both general increases and decreases. 
In Harrison Area 2, three wells with five samples each were plotted to observe TDS variations over time. (Figure 25). Unlike Harrison Area 1, the wells in Harrison Area 2 showed relatively similar behaviors. All samples showed a general decrease in TDS concentration over time that became more pronounced if only samples taken after 365 days were considered. One well had a fifth sample much higher than its fourth sample, but still lower than the maximum TDS concentration seen in the second sample. Overall, the slope of the trendlines indicated a slower rate of decline in Harrison Area 2 than in any of the other four areas

TDS concentrations over time are much different in the Central Taylor Area than in both Harrison areas. Five wells with five samples indicated steadily decreasing TDS concentrations over time (Figure 26). The rates of decrease were faster than those seen in Harrison Area 2, and most samples showed TDS concentrations less than the previous sample indicating little oscillation over time. Four of the maximum concentrations are seen within the first two years. The only well that did not fit this description had a long period between its second and third samples, so the maximum concentration likely occurred during time and was not observed due to the extended period between samples.

The Northeast Taylor Area contained three wells with five samples each taken since initial flowback began. These samples showed similar traits to those observed in Central Taylor. There was a general decrease in TDS concentrations over time at a rate higher than those found in Harrison Area 2 (Figure 27). Two of the three wells showed maximum TDS values within the first 300 days of production with the third well having its maximum within 700 days again an indication that maximum TDS concentrations occur within the first two years of production. 


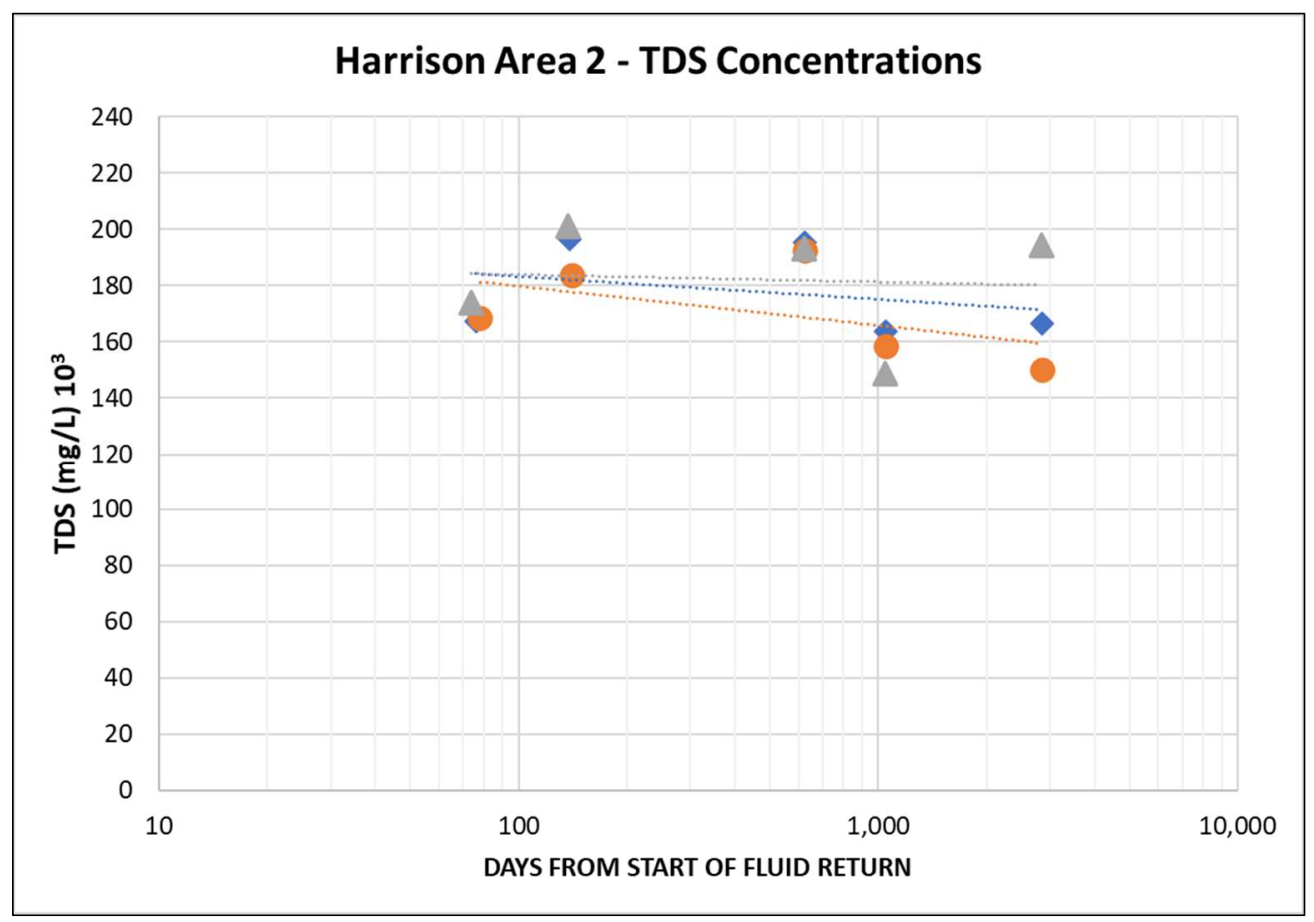

Figure 25-TDS concentrations for three wells in Harrison Area 2 with five samples each. Concentrations indicate a general decrease in TDS concertation over time, particularly considering samples taken after the 365 days. One well shows a significant increase between sample four and five but maintains a slight decreasing trend.

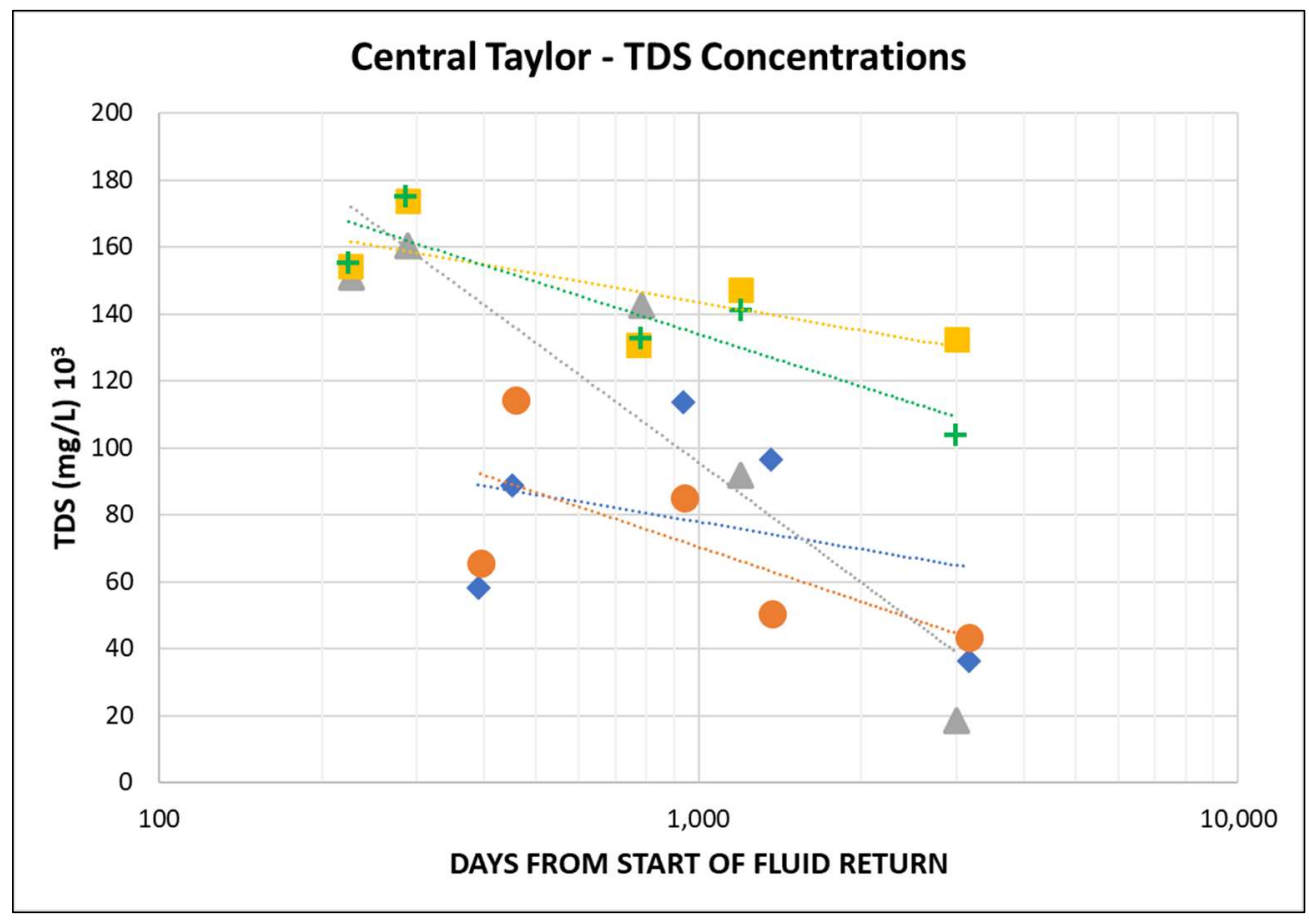

Figure 26-TDS concentrations for five wells in Central Taylor with five samples each. Concentrations indicate a general decrease in TDS concertation over time, particularly samples taken after the 500 days. 
Multiple samples in this area had higher TDS concentrations subsequent to a previous sample, however, the most recent sample collected for each well indicated the lowest TDS concentrations to date, indicating that while concentrations fluctuated between samples, they still declined over time and remained well below maximum TDS concentrations.

The Monongalia area contains four wells, two of which have produced water samples used in this study. Each well had 12 samples, however all but one of these sample was taken prior to day 500 of production. As a result, the trendlines reflect this early lifespan data and do not represent data trends after the first two years. One sample taken for each well after Day 1,700 showed behavior that mirrors Central Taylor and Northeast Taylor (Figure 28). Both wells showed maximum TDS concentrations between year one and year two after which TDS concentrations began to decline. A decrease in TDS concentrations over time was also reported for two wells associated with the MSEEL project not included in this study (Ziemkiewicz, 2017).

When considering individual ion concentrations overall, the major ions $(\mathrm{Ca}, \mathrm{Na}$, and $\mathrm{Cl})$ tended to follow the overall trend of TDS concentrations, but occasionally fluctuated away from this behavior. There were some cases of minor ion concentrations such as barium, strontium, and iron increasing while overall TDS decreased. This did not have a large effect on the overall ionic proportions, as the major ions significantly overshadowed the minor ions. The only time this was significant was a few samples in the Central Taylor Area where TDS concentrations were extremely low $(<6,500 \mathrm{mg} / \mathrm{L})$ and iron made up a significantly higher proportion of ions, which could be caused by iron processes not mentioned in this study. 


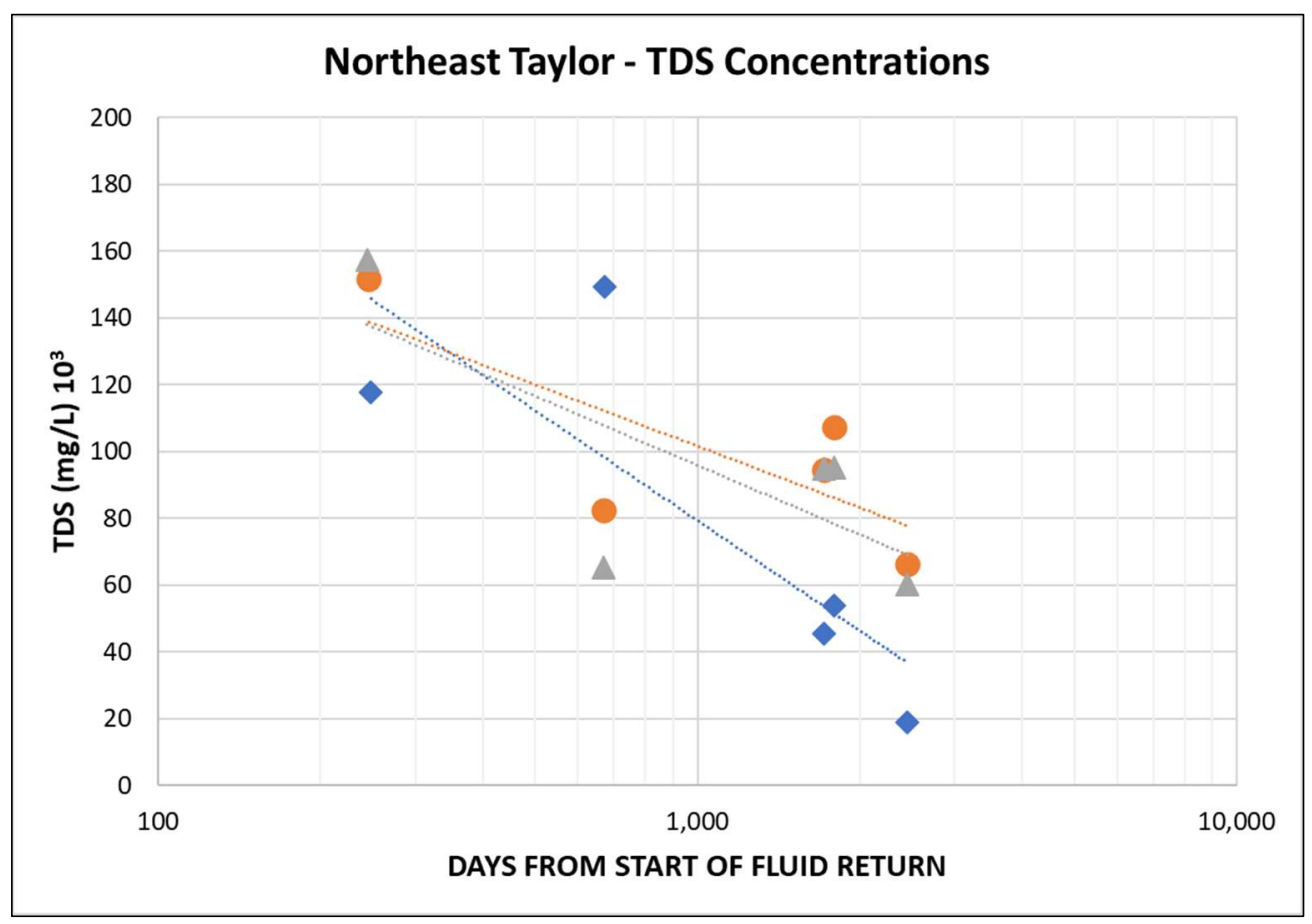

Figure 27-TDS concentrations for three wells in Northeast Taylor with five samples each. Concentrations indicate a general decrease in TDS concertation over time. Some minor increases may be seen from one sample to the next, but the increase is lower than maximum TDS concentrations.

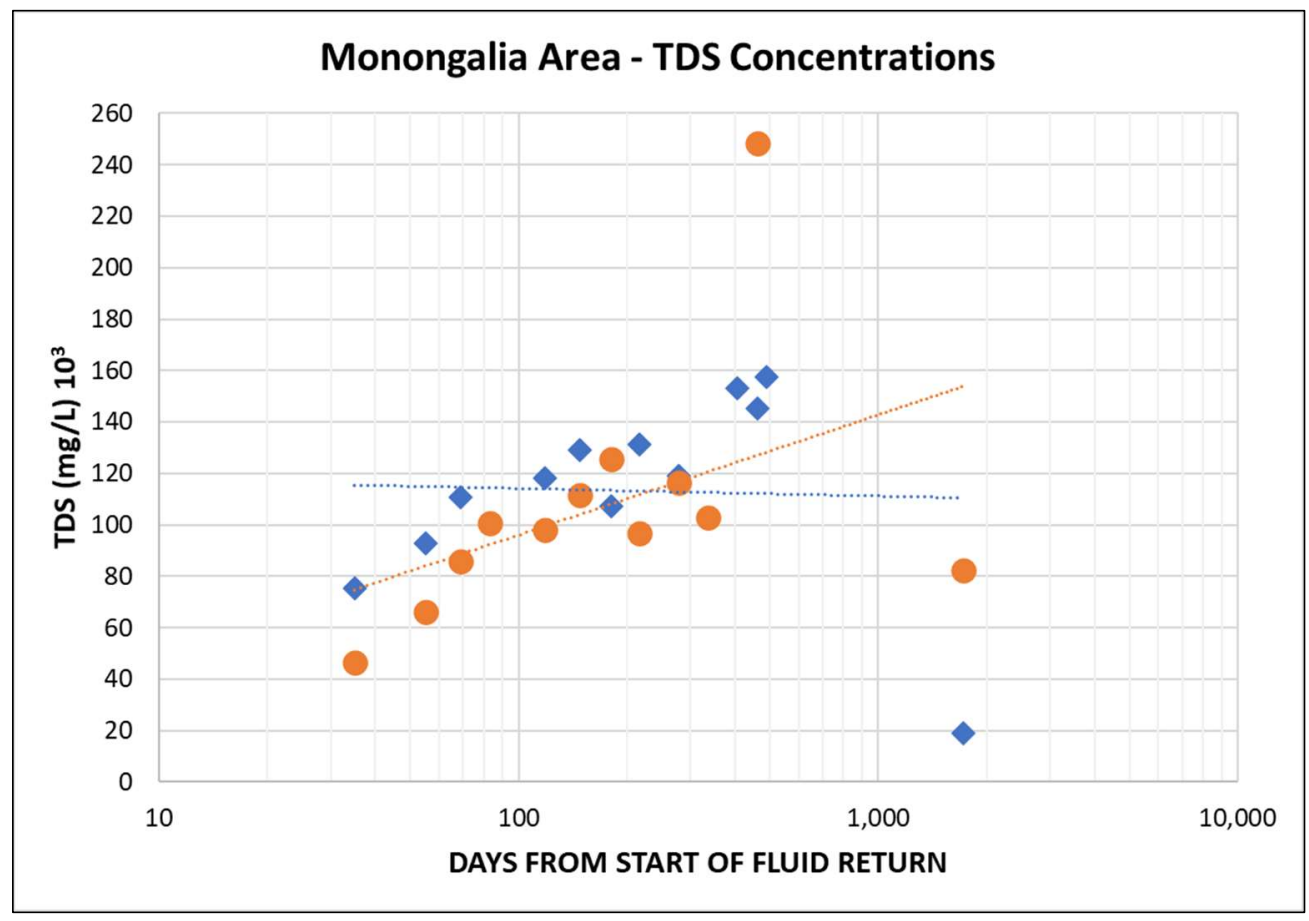

Figure 28 - TDS concentrations for two wells in Monongalia with 12 samples each. Samples show maximum TDS concentrations in the first 1 to 2 years. Samples taken after 500 days indicate a general decrease in TDS concertation over time. 


\section{DISCUSSION}

The results of the tests performed across the five areas in this study indicated that geologic differences exist across the study area. These differences were observed in both traditional rock analysis methods like XRD, pyrolysis, and well logs, as well geochemical methods using produced water samples. Additionally, analyzing produced water samples provided some insight into fluid-rock interactions that may have occurred, which could explain differences in production among the areas.

\section{Well Log and Core Data}

The first indication of geological differences among the five area was observed simply by looking at the normalized gamma-ray logs. Harrison areas 1 and 2 had a slightly hotter gammaray value in the upper Marcellus than Central Taylor, Northeast Taylor, and Monongalia (Figure 8). This trend reversed when looking at the middle and lower Marcellus. Central Taylor, Northeast Taylor and Monongalia had noticeably higher gamma-ray intensities across those sections than the Harrison areas with the biggest gamma-ray difference in the lower Marcellus. Variations were also observed in the density curves where the Harrison areas had lower densities than the other three areas. To determine if the difference in gamma ray and densities were caused by differences in organic content, studies performed by Schmoker (1979, 1981, 1993) associating gamma-ray intensity to TOC content in Appalachian black shales were considered.

Schmoker concluded that black shales tended to have higher gamma-ray intensities because of the association between uranium and organic matter content (Schmoker 1981, 1993). To determine if the gamma ray and density differences across the study area varied due to changing 
organic content, gamma-ray values and log-calculated TOC values were determined from well logs and compared to TOC values derived from cores using pyrolysis. Figure 11 indicated that log-calculated TOC values provided a relatively good estimation of TOC with slight underestimation in Central Taylor, Northeast Taylor, and Monongalia. As expected, both logcalculated and core-derived TOC increased as gamma-ray values increase (Charts in Appendix A). Comparisons among the five areas showed that the highest log-calculated TOC values were in the Harrison areas with slightly lower values in the other three areas. This was contrary to Schmoker's conclusion of higher gamma-ray values indicated higher TOC, although Schmoker acknowledged local variations exist. While the difference could be caused by limited sampling from the Harrison Area 1 and Central Taylor cores, mineralogy and produced water samples may provide insight into the difference between areas.

When comparing mineralogy among the areas in this study, it was determined that ELAN logs were adequate for estimating relative quartz, clay, and carbonate content for Harrison Area 1 and Central Taylor. This was important given the low XRD sampling density from the cores. In Monongalia, higher density XRD sampling was performed and showed that the ELAN log for that area overestimated the amount of quartz, so XRD values were used for comparison to Harrison Area 1 and Central Taylor (Figure 16). When averaging quartz, clay, and carbonate weight $\%$ with no kerogen across the entire Marcellus interval, Harrison Area 1 had 42.2\%, $40.3 \%$, and $12.3 \%$ respectively. Central Taylor had $36.3 \%$ quartz, $44.6 \%$ clay, and $12.1 \%$ carbonate. Monongalia had $31.2 \%$ quartz, $48.7 \%$ clay, and $8.3 \%$ carbonate. The remaining weight $\%$ was composed of mainly pyrite and $\sim 1 \%$ or less of barite. These mineralogy results showed similarities between Central Taylor and Monongalia in that clay minerals comprised the 
highest proportion of the formation. In both cases, there was significantly more clay minerals than quartz minerals. The opposite was observed in Harrison Area 1 where quartz minerals comprised a slightly higher proportion of the formation than clay minerals. Carbonate minerals accounted for similar proportions in all areas with $<1 \%$ difference between Harrison Area 1 and Central Taylor with those two areas having $\sim 4 \%$ more than Monongalia. The slightly lower proportion in Monongalia could be the results of sampling gaps that missed higher carbonate sections of the core. Regardless, carbonate among the three areas was relatively close. Mineralogy ultimately tied back to gamma-ray intensity in that quartz and carbonate minerals have lower gamma-ray intensities than clay minerals. Since Harrison Area 1 shows a higher percentage of quartz minerals and slightly more carbonate than Central Taylor and Monongalia, it may have caused the slightly lower gamma-ray intensities in the Harrison areas even though pyrolysis and log-calculated TOC values were similar among all areas.

Differences in quartz, carbonate, and clay mineralogy likely accounted for gamma-ray intensity variations across the study area and produced water analysis results provided additional evidence that mineralogical differences exist. Harrison areas 1 and 2 showed higher calcium and strontium concentrations than Central Taylor, Northeast Taylor, and Monongalia. Alternatively, barium was higher in Central Taylor, Northeast Taylor, and Monongalia than in the Harrison areas. It should also be noted that core-derived XRD values for barite were slightly higher in Central Taylor and Monongalia than in Harrison Area 1. Studies suggested that elevated calcium and strontium values were caused by carbonate alteration associated with limestone and other carbonates, while elevated barium values were caused by silicate/clay alteration typically associated with shales (Dresel and Rose, 2010, Chapman et al., 2012, and Phan et al., 2020). 
Low concentrations of both strontium and barium were typically found in sandstones. If higher calcium and strontium concentrations were associated with higher limestone content, then produced-water samples indicated a more carbonate-rich Marcellus section in the Harrison areas than in the other three areas. Since XRD showed relatively similar carbonate proportions across the study area, the excess carbonate may reside in carbonate cement or a higher-density of calcite-filled, microfracture networks. Higher carbonate content in the rock would result in a relatively lower gamma-ray intensity when compared to Central Taylor, Northeast Taylor, and Monongalia, which had elevated barium values typical of shale and result in higher gamma-ray intensities.

\section{Carbonate Dissolution}

Multiple studies have found varying amounts of carbonate dissolution within the Marcellus Shale (Chapman et al., 2012, Phan et al., 2020, Sharma et al., 2021). The primary sources of carbonate from dissolution during fracture stimulation could be carbonate cements, calcite-filled fractures, and limestone itself. Dissolution of in-situ carbonates was likely initiated by acid run during each stage of hydraulic fracturing. Indicators of carbonate dissolution in produced water were found by comparing $\mathrm{Sr} / \mathrm{Na}$ ratios and $\mathrm{Ca} / \mathrm{Na}$ ratios to $\mathrm{Cl}$ concentrations. A recent study looked at $\mathrm{Sr} / \mathrm{Na}$ and $\mathrm{Ca} / \mathrm{Na}$ ratios for two wells in the MSEEL project and determined pathways that indicated either fracturing fluid mixing with formation water, pure formation water, or carbonate cement dissolution (Phan et al., 2020). Superimposing the $\mathrm{Sr} / \mathrm{Na}$ and $\mathrm{Ca} / \mathrm{Na}$ ratios vs. $\mathrm{Cl}$ values for the five areas in this study showed samples falling in all three pathways (Figure 29). Two Monongalia wells that used the same produced water samples in both studies have data points that sit directly on top of one another. Central Taylor, Northeast Taylor, and Monongalia samples 
showed extensive mixing with formation water, with some sample having a high enough $\mathrm{Sr} / \mathrm{Na}$ and $\mathrm{Ca} / \mathrm{Na}$ ratios combined with chloride concentrations to be considered formation water. Some Central Taylor samples showed signs of carbonate cement dissolution when observing $\mathrm{Sr} / \mathrm{Na}$ ratios. Samples from Harrison areas 1 and 2 indicated some mixing with formation water, but most of the samples have $\mathrm{Sr} / \mathrm{Na}$ and $\mathrm{Ca} / \mathrm{Na}$ ratios higher than the path expected for pure formation water indicating that some degree of carbonate dissolution occurred. When considering TDS over time, Harrison areas 1 and 2 displayed different behaviors than the other three areas which may indicate dissolution is occurring well after hydraulic fracturing ceased or the influence of rock-fluid interactions that occurred during hydraulic fracturing are still being observed years later. This may also explain the higher TDS concentrations observed in the Harrison areas.

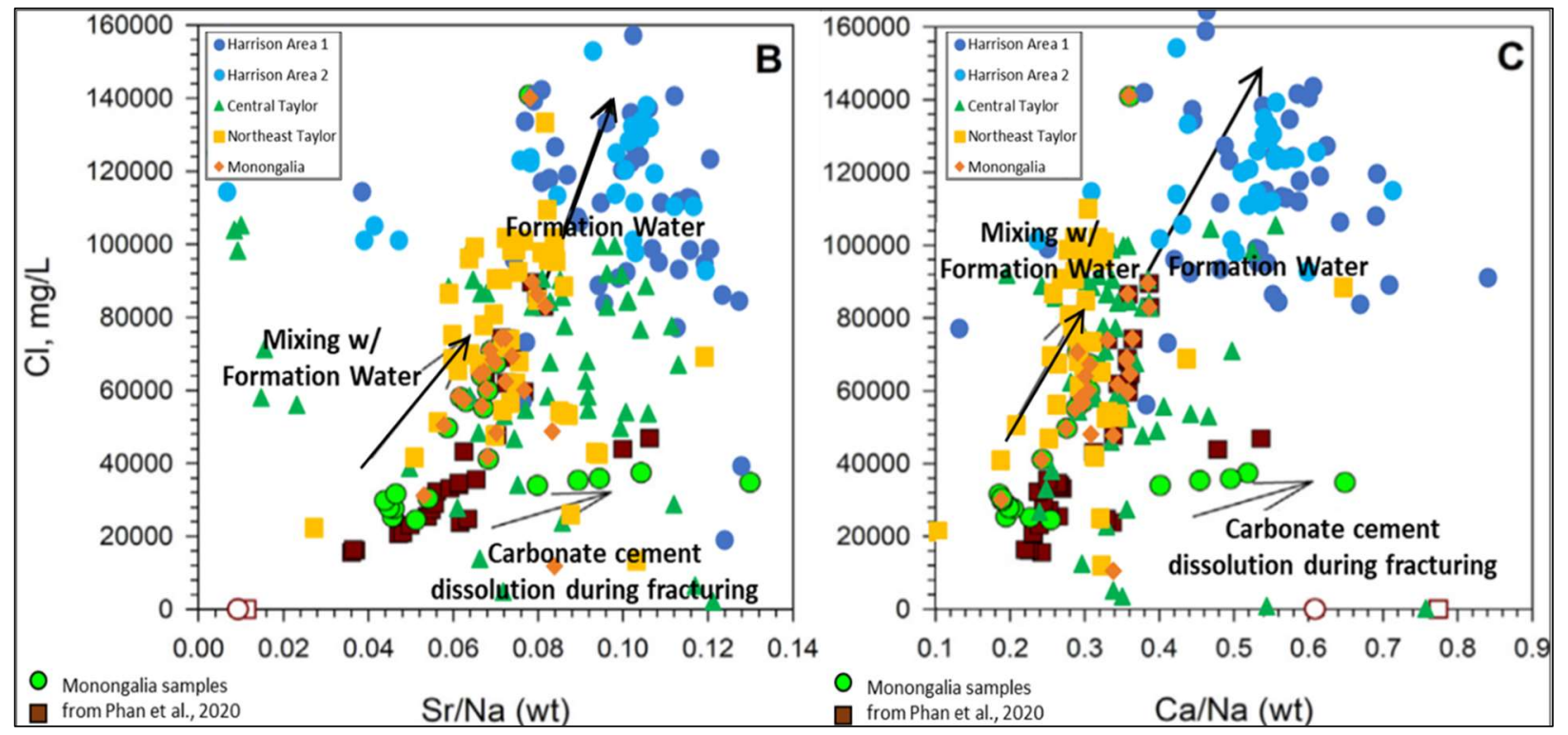

Figure 29-A.) $\mathrm{Sr} / \mathrm{Na}$ vs $\mathrm{Cl}$ for all samples across the five areas in the study. $\mathrm{B}$.) $\mathrm{Ca} / \mathrm{Na} v \mathrm{vs}$. $\mathrm{Cl}$ for all samples across the five areas in this study. Samples are compared to those plotted by Phan et al., (2020) showing three pathways for produced water samples. Results indicate Central Taylor, Northeast Taylor, and Monongalia samples are mixed formation water and fracturing fluid trending toward formation water. Harrison areas 1 and 2 samples indicate pure formation water mixing with carbonate dissolution (modified from Phan et al., 2020). 
Other than carbonate dissolution, elevated $\mathrm{Ca} / \mathrm{Na}$ ratios could be the result of calcium-rich brines sourced from the Silurian (Hanor et al., 2006, Dresel and Rose 2010.). However, a study performed looking at this scenario in similar geologic settings in the Illinois and Michigan basins did not show trends that indicate progressively evaporated $\mathrm{CaCl}_{2}$-rich Silurian seawater as the source (Hanor et al., 2006). The study determined that the $\mathrm{Mg} / \mathrm{Ca}$ ratios were significantly less than evaporated Silurian seawater and therefore Silurian-aged brines could not be the source. Indeed, many studies concluded that Marcellus brines resulted from evaporated seawater typically associated with other Devonian-age brines in the Appalachian Basin (e.g. Dresel and Rose, 2010, Haluszczak et al, 2013, and Rowan et al., 2015). Comparing the $\mathrm{Na}+\mathrm{K}, \mathrm{Ca}$, and $\mathrm{Mg}$ concentrations from this study to those in Rowen et al., (2015) show very similar pathways exist, particularly between southwest PA, Central Taylor, Monongalia, and Northeast Taylor (Figure 30). Harrison Area 1 and Harrison Area 2 samples plotted nearly in the middle of the

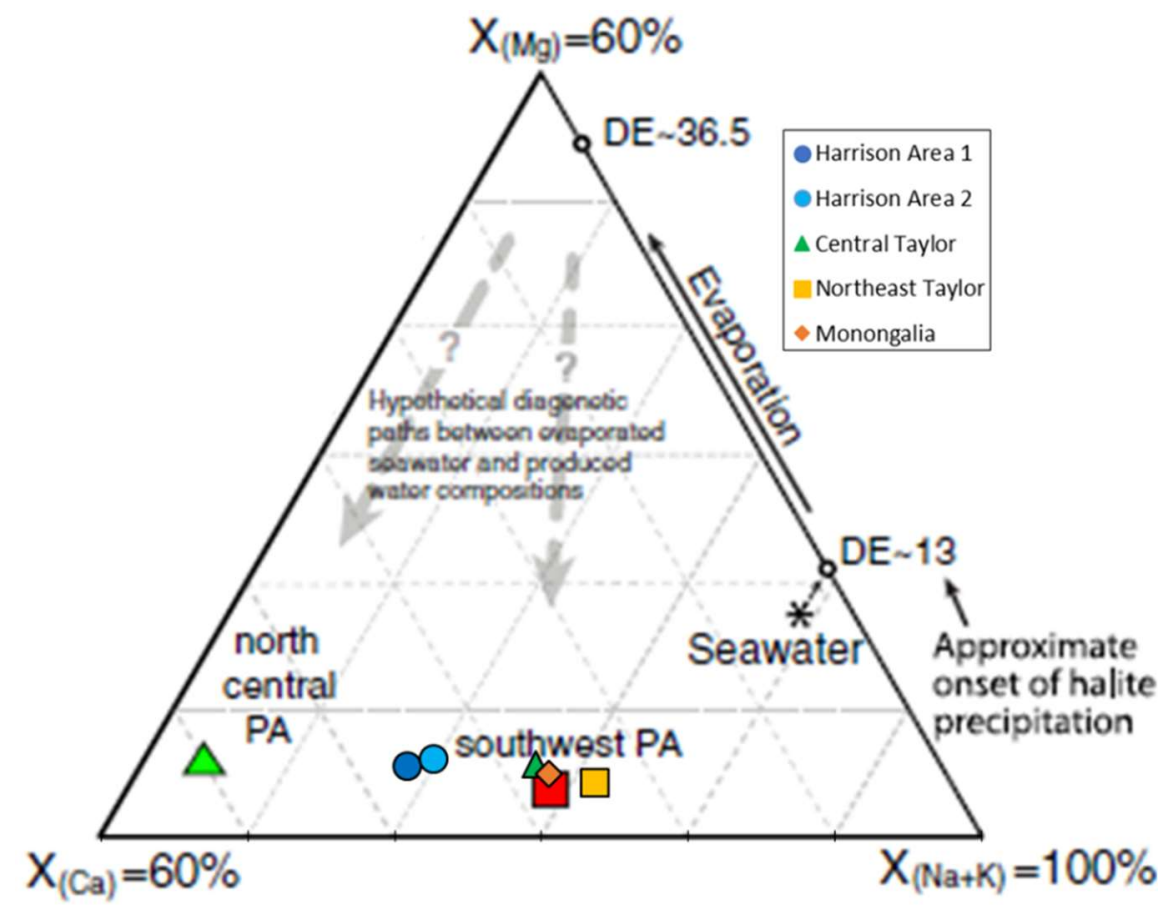

Figure 30 - Ternary plot comparing equivalent ratios of major cations in Marcellus Shale water samples. Samples from this study are superimposed on plot from Rowan et al.,2015 to show similar pathways from evaporated seawater to produced water compositions for samples taken from northcentral and southwest PA. (modified from Rowan et al., 2015). 
northcentral PA and southwest PA samples, with slight trending toward southwest PA. These pathways indicated that some of the excess calcium in the Harrison areas likely originated from evaporated seawater, however, the plotted $\mathrm{Sr} / \mathrm{Na}$ and $\mathrm{Ca} / \mathrm{Na}$ ratios indicated some carbonate dissolution occurred.

\section{TDS Evolution over Time}

As previously mentioned, most studies looking at Marcellus Shale produced water chemistry focused on the first few years of production. These studies consistently showed rapidly increasing TDS and ionic concentrations over the first months of fluid return followed by a leveling off period. These maximum TDS concentrations were thought to represent formation water and be characteristic of produced water moving forward (Rowan et al., 2015, Kondash et al., 2017, Osselin et al., 2018). In this study, results of produced water samples spanning up to ten years from initial fluid production indicated this is not always the case and in fact, most wells in this study exhibited declining TDS concentrations after the second year of production.

In general, TDS concentrations tended to reach maximum levels between year 1 and year 2 of production with some wells reaching maximum concentrations later (Figures $26-30$ ). This was followed by varying rates of decreasing TDS levels. Harrison Area 1 was the only area in this study with multiple wells showing significantly increasing TDS concentration over their lifespan. Harrison Area 2 displayed relatively flat, to slightly decreasing TDS concentrations. Central Taylor, Northeast Taylor, and Monongalia showed significant declines in TDS concentrations over time. A few wells in Northeast Taylor had slight TDS increases between samples, but a lack of sampling during year 2 likely missed the TDS maximum so a true decline cannot be determined without continued testing. Differences in behavior could be caused by continued 
carbonate dissolution in the Harrison areas that keeps the TDS concentrations elevated compared to the other areas. The different behavior could have also resulted from a higher volume of formation fluid released during fracturing or a better fracture network that resulted in more rockfluid interactions. The last two could also explain the higher fluid return percentages in the Harrison areas.

To determine the potential TDS contribution from formation water, a mass balance approach was developed using the equation:

$$
\text { Percentage of Final TDS }=\frac{\operatorname{TDS}(\mathrm{x})-\mathrm{TD}(\text { day } 1)}{\operatorname{TDS}(\text { final })-\operatorname{TDS}(\text { day } 1)}
$$

where TDS(x) is the TDS of water at day $\mathrm{x}$ after hydraulic fracturing, TDS (final) is the maximum TDS reported, and TDS (day 1) is the TDS of the water on Day 1 of flowback, representing $0 \%$ brine contribution (Kondash et al., 2017). This approach is useful to characterize the composition of produced water over time and describe well behavior. In some instances, TDS concentrations fluctuated higher and lower over time indicating dynamic fracturing fluid to formation water ratios. Using this ratio over time may show slugs of fracturing fluid coming back to the surface that were trapped by pressure blocks or indicate the opening of a previously non-producing perforation or fracture network. Alternatively, a decrease in TDS concertation over time may represent exhaustion of available formation water or a reduction in carbonate dissolution and other rock-fluid interactions.

\section{Influence on Natural Gas Production}

One important reason for understanding geological behaviors is to maximize natural resource extraction in the most cost-effective manner. Results presented in this study show distinct 
differences in produced water chemistry, fluid return behavior, well log signatures, TOC, and mineralogy across the study area. Harrison Area 1 and Harrison Area 2 shared many of the same geological traits, while Central Taylor, Northeast Taylor, and Monongalia areas shared similar traits that differed from the Harrison areas. To observe the effect these variations had on production, daily natural gas production was obtained for all 74 wells in this study. To normalize production for varying lateral lengths, daily cumulative production was divided by total lateral length to produce a value given in thousand cubic feet per lateral foot $(\mathrm{mcf} / \mathrm{ft})$.

Normalized cumulative production for the first 2,000 days ( $\sim 5.5$ years) of each well showed ranges that again varied by area. Wells in Harrison Area 1 generally fell between $600-900$ $\mathrm{mcf} / \mathrm{ft}$ with a few wells above and below that range (Figure 31A). Wells younger than 2,000 days followed trends that should exceed $600 \mathrm{mcf} / \mathrm{ft}$ by the time they reach that age. Wells in Harrison Area 2 also generally fell between $600-900 \mathrm{mcf} / \mathrm{ft}$ (Figure 31B). Two wells fell just below 600 $\mathrm{mcf} / \mathrm{ft}$ with one additional well around $500 \mathrm{mcf} / \mathrm{ft}$. Several wells were on pace to exceed 900 $\mathrm{mcf} / \mathrm{ft}$ when they reach 2,000 days of production. Similar to observed geologic trends, Harrison areas 1 and 2 shared very similar production trends. Also similar to geologic trends, production rates differed moving east to the other three areas. Central Taylor had a general production range of $400-700 \mathrm{mcf} / \mathrm{ft}$ with only two wells exceeding that rate (Figure 31C). Multiple, younger wells were on pace to exceed this range, with no wells testing the lower boundary. Only three wells in Northeast Taylor exceeded 2,000 days in production, but they indicated a range of $400-$ $700 \mathrm{mcf} / \mathrm{ft}$ (Figure 31D). Of the wells yet to reach 2,000 days, a couple may exceed the upper range and one may stay below the lower range. The Monongalia area had the fewest wells among the five areas and showed a production range of $400-800 \mathrm{mcf} / \mathrm{ft}$ (Figure 31E). Two 
wells have yet to reach 2,000 days, but they were also the higher producing wells and projected the upper range of $800 \mathrm{mcf} / \mathrm{ft}$. In many of the geologic aspects discussed, Central Taylor, Northeast Taylor, and Monongalia shared similar traits with minor variations; this was again the case when considering production ranges over the first 2,000 days.

Differences in gas production among the five areas can be related to geologic trends. Harrison areas 1 and 2 show slightly higher cumulative production rates than the other three areas. Potential reasons this was occurring can be linked back to TOC, mineralogy, or carbonate dissolution. Log-calculated TOC values indicated higher content in the Harrison areas and higher TOC is a good indication of higher gas content. However, underestimated log-calculated TOC values in Central Taylor, Northeast Taylor, and Monongalia and low sample density in Harrison Area 1 made it difficult to determine the relative differences. Mineralogy reveals that Harrison areas 1 and 2 had a higher quartz content, whereas Central Taylor, Northeast Taylor, and Monongalia had a higher clay content. This is important because more brittle minerals such as quartz tend to produce a better fracture network during hydraulic fracturing whereas clay minerals absorb more energy before fracturing leaving less energy to propagate fractures. Additionally, minerals such as quartz have less ability to adsorb gas than clay minerals, so the ratio of free gas to adsorbed gas is higher when more quartz minerals are present (Wang and Carr, 2012). Higher clay content in Central Taylor, Northeast Taylor, and Monongalia was also indicated from produced water samples. Barium concentrations were higher in those three areas and higher barium concentrations indicate more clay-rich shale (Dresel and Rose, 2010). Higher calcium and strontium concentrations in produced water from Harrison areas 1 and 2 indicated a higher carbonate content, possibly as carbonate cement, which would also lead to increased 

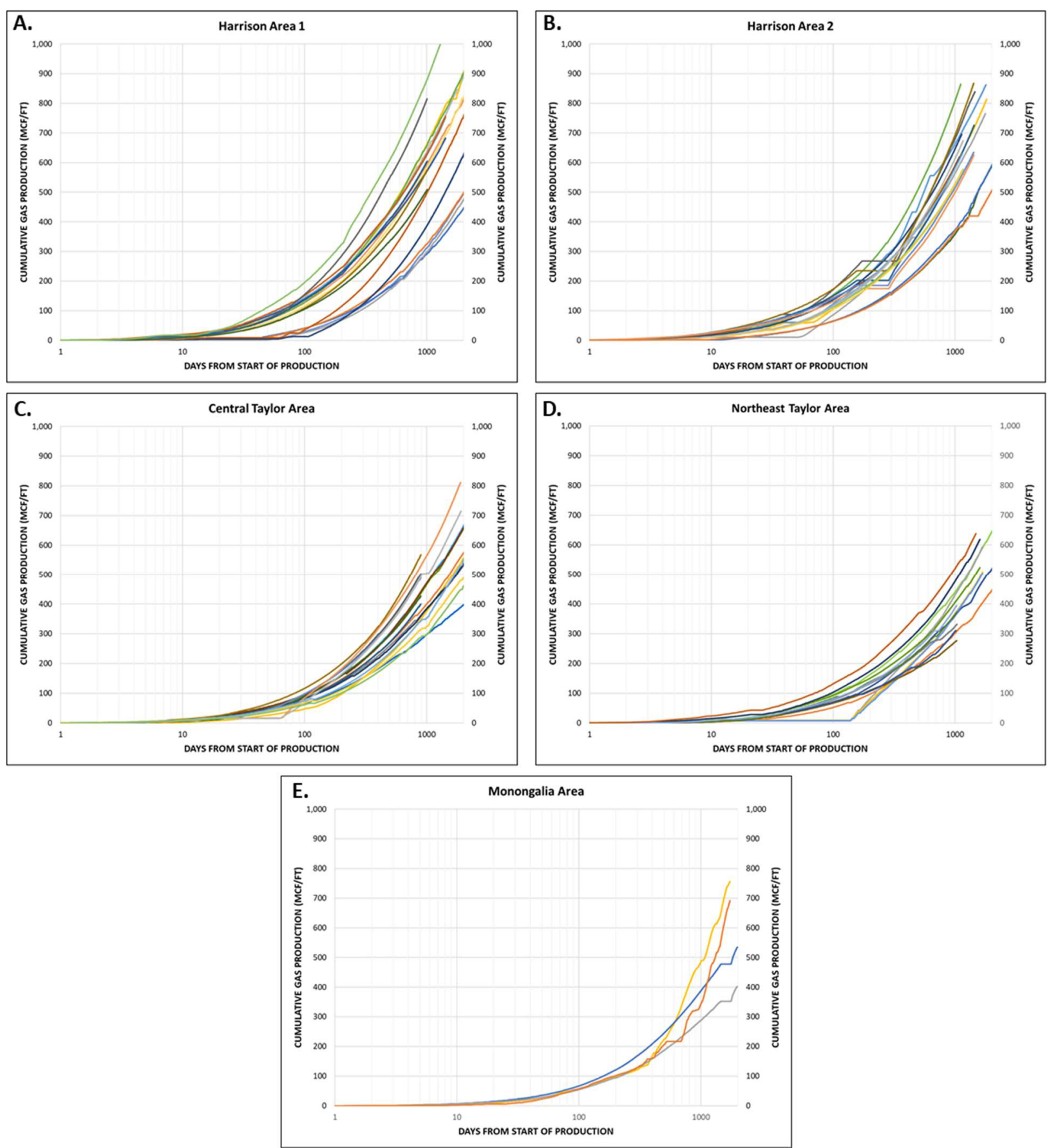

Figure 31 - Cumulative gas production for the first 2,000 days ( 5.5 years) in each area normalized to $\mathrm{mcf} / \mathrm{ft}$. A.) Harrison Area 1 has a typical range of $600-900 \mathrm{mcf} / \mathrm{ft}$ with a few wells above and below this level. B.) Harrison Area 2 has a typical range of $600-900 \mathrm{mcf} / f t$. with only one well significantly below this level. C.) Central Taylor has a typical range of $400-$ $700 \mathrm{mcf} / \mathrm{ft}$ with two wells above this level. D.) Northeast Taylor has a typical range of $400-700$ $m c f / f t$ with no wells exceeding this range and a few below. E.) Monongalia has a typical range of $400-800 \mathrm{mcf} / \mathrm{ft}$ will all wells currently in this range. 
brittleness allowing for more effective fracturing. The higher calcium and strontium concentrations indicated more carbonate dissolution may be occurring in the Harrison areas. This would enhance porosity and permeability, opening additional and bigger pathways for the gas to flow to the wellbore. This would also explain the generally higher percentages of produced fluid returned across the Harrison areas.

While geologic factors are paramount in determining the ultimate amount of gas that can be extracted from the reservoir, it should be noted that extenuating factors outside of geologic differences play a role in cumulative production. Completion practices with differences in stage spacing, proppant concentrations, completion fluid composition and other factors have changed over time. Gas market restrictions that require wells to be shut-in for extended periods or flowed at rates lower than maximum can suppress cumulative production. Operational shut-ins related to compressor shut-downs, pipeline and well maintenance, or hydraulic fracturing of offset wells also influence cumulative production. Each of these scenarios has played out to some extent in each of the five areas in this study. However, it is unlikely that these production restrictions are significantly altering the general production ranges seen in each area.

\section{CONCLUSIONS}

An investigation of produced water samples and cumulative gas production pointed to changing geologic conditions across the study area that was supported by well logs and core data (TOC and XRD mineralogy). Results indicated that several of these geologic changes can be surmised from produced water chemistry. Additionally, the 10 -year time period covered by the water 
samples in this study illustrated compositional trends outside of the immediate influence of hydraulic fracturing. The findings of this study include:

- Geologic conditions change across the study area. Harrison Area 1 and Harrison Area 2 share similar geologic characteristics. Central Taylor, Northeast Taylor, and Monongalia areas share similar geologic characteristics that are different than those found in the Harrison areas.

- Major and minor ions from produced water samples provide insight to relative geologic changes across the area. Increasing barium concentrations indicate higher clay content as observed in Central Taylor, Northeast Taylor, and Monongalia. Increasing calcium and strontium concentrations indicate higher carbonate content and the potential for carbonate dissolution as observed in Harrison Area 1 and Harrison Area 2.

- TDS concentrations in produced waters typically reach peak values within the first two years of production. This is followed by varying rates of decreasing concentration, which appear to be linked to geologic characteristics such as volume of formation water available, carbonate dissolution, and clay content.

- As TDS concentrations begin to decline, ionic proportions stay relatively consistent indicating fluid-rock interactions remain consistent. Samples showing major changes typically return to the expected range in subsequent samples. 
- TDS fluctuations during decline are normal and represent varying ratios of formation water mixing with hydraulic fracturing fluid. Fluctuations may be caused by downhole behaviors such as release of pressure blocked fracturing fluid, or the opening of a previously closed perforation or fracture network.

- The set of geologic characteristics in Harrison Area 1 and Harrison Area 2 show higher cumulative gas production per well over the initial 2,000 days (5.5 years) and higher total fluid return percentages than the wells in Central Taylor, Northeast Taylor, and Monongalia areas.

The conclusions in this study demonstrate the utility of continued produced-water testing during the entire lifespan of a well. Varying concentrations in water samples indicate dynamic conditions over the life of a well and differs from expected trends extrapolated in studies focusing on the first few months to years of a well's lifespan. Continued testing provides insight into a well's production and may reveal subtle geologic differences that are typically only found using more expensive tests such as rock pyrolysis and XRD analysis from core or well cuttings. This study confirms that the Marcellus Shale is a complex, heterogenous reservoir that requires continuous study even after more than a decade of development and emergence as a world-class reservoir.

\section{REFERENCES CITED}

Balashov, V.N., T.Engelder, X. Gu, M.S. Fantle, and S.L. Brantley, 2015, A model describing flowback chemistry changes with time after Marcellus Shale hydraulic fracturing: AAPG Bulletin, v. 99, no. 1, p. 143-154. https://doi.org/10.1306/06041413119 
Barbot, E., N.A. Vidic, K.B. Gregory, and R.D. Vidic, 2013, Spatial and temporal correlation of water quality parameters of produced waters from Devonian-age shale following hydraulic fracturing: Environmental Science \& Technology, v. 47, p. 2562-2569. https://doi.org/10.1021/es304638h

Blauch, M.E., R.R. Myers, T.R. Moore, B.A. Lipinski, and N.A. Houston, 2009, Marcellus Shale post-frac flowback waters: Where is all the salt coming from and what are the implications?: Society of Petroleum Engineers, SPE 125740, 20p. https://doi.org/10.2118/125740-MS

Boswell, R. M., and S. E. Pool, 2018, Lithostratigraphy of Middle and Upper Devonian OrganicRich Shales in West Virginia: West Virginia Geological \&Economic Survey, Reports of Investigation RI-35, $47 \mathrm{p}, 31 \mathrm{f}$.

Byrnes, A.P., 2011, Role of induced and natural imbibition in frac fluid transport and fate in gas shales: Technical Workshops for Hydraulic Fracturing Studies - Fate \& Transport, Arlington Virginia, March 28-29, 2011

Capo, R.C., B.W. Stewart, E.L. Rowan, C.A. Kolesar Kohl, A.J. Wall, E.C. Chapman, R.W. Hammack, and K.T. Schroeder, 2014, The strontium isotopic evolution of Marcellus Formation produced water, southwestern Pennsylvania: International Journal of Coal Geology, v. 126, p. 57-63. https://doi.org/10.1016/j.coal.2013.12.010

Chapman, E.C., R.C. Capo, B.W. Stewart, C.S. Kirby, R.W. Hammack, K.T. Schroeder, and H.M. Edenborn, 2012, Geochemical and strontium isotope characterization of produced waters from Marcellus Shale natural gas extraction: Environmental Science \& Technology, v. 46, p. 3545-3553. https://doi.org/10.1021/es204005g

Dresel, P.E. and A.W. Rose, 2010, Chemistry and origin of oil and gas well brines in western Pennsylvania: Pennsylvania Geological Survey, $4^{\text {th }}$ series, Open-File Report OFOG 10$01.0,48 \mathrm{p}$.

Engelder, T., 2012, Capillary tension and imbibition sequester frack fluid in Marcellus gas shale: Proceedings of the National Academy of Sciences of the United States of America, v. 109, p. 3625. https://doi.org/10.1073/pnas.1216133110

Engle, M.A. and E.L. Rowan, 2014, Geochemical evolution of produced waters from hydraulic fracturing of the Marcellus Shale, northern Appalachian Basin: A multivariate compositional data analysis approach: International Journal of Coal Geology, v. 126, p. 45-56. https://doi.org/10.1016/j.coal.2013.11.010

Ettensohn F.R., 1985, The Catskill Delta complex and the Acadian Orogeny: A Model, in Woodrow, D.L., Sevon, W.D., eds., The Catskill Delta: Geologic society of America Special Paper 201, p.246. https://doi.org/10.1130/SPE201-p39

Evans, M.A., 1995, Fluid inclusions in veins from the Middle Devonian shales: A record of 
deformation conditions and fluid evaluation in the Appalachian plateau: Geological Society of America Bulletin, v. 107, no.3, p.327-339. doi.org/10.1130/00167606(1995) $107<0327:$ FIIVFT $>2.3$. CO;2

Haluszczak, L.O., A.W. Rose, and L.R. Kump, 2013, Geochemical Evaluation of Flowback Brine from Marcellus Gas Wells in Pennsylvania, USA: Applied Geochemistry, v. 28, p. 55-61, doi.org/10.1016/j.apgeochem.2012.10.002

Hanor, J.S. and J.C. Mcintosh, 2006, Are secular variations in seawater chemistry reflected in the compositions of basinal brines?: Journal of Geochemical Exploration, v. 89, p. 153-156. https://doi.org/10.1016/j.gexplo.2005.11.054

Hupp, B. N., 2017, Provenance of the Hamilton Group: A Study of Source-to-Sink Relationships within the Middle Devonian Central Appalachian Basin: Graduate Theses, Dissertations, and Problem Reports, 5846. https://doi.org/10.33915/etd.5846

Hupp, B.N and J.J. Donovan, 2018, Quantitative mineralogy for facies definition in the Marcellus shale, Appalachian Basin, USA, using XRD-XRF integration: Sedimentary Geology, v. 371, p. 16-31. https://doi.org/10.1016/j.sedgeo.2018.04.007

Kanfar, M.S. and C.R. Clarkson, 2016, Reconciling flowback and production data: A novel history matching approach for liquid rich shale wells: Journal of Natural Gas Science and Engineering: v. 33, p. 1134 - 1148. https://doi.org/10.1016/j.jngse.2016.04.042

Kondash, A.J., E. Albright, and A. Vengosh, 2017, Quantity of flowback and produced waters from unconventional oil and gas exploration: Science of The Total Environment, v. 574, p. 314-321. https://doi.org/10.1016/j.scitotenv.2016.09.069

Lash G. G., and T. Engelder, 2011. Thickness trends and sequence stratigraphy of the Middle Devonian Marcellus Formation, Appalachian Basin: Implications for Acadian foreland basin evolution: AAPG Bulletin, v. 95, no. 1, p. 61-103. https://doi.org/10.1306/06301009150

Osselin, F., M. Nightingale, G. Hearn, W. Kloppmann, E. Gaucher, C.R. Clarkson, and B. Mayer, 2018, Quantifying the extent of flowback of hydraulic fracturing fluids using chemical and isotopic tracer approaches: Applied Geochemistry, v. 93, p. 20-29. https://doi.org/10.1016/j.apgeochem.2018.03.008

Paronish, T.J., 2018, Meso-and Macro-scale facies and chemostratigraphic analysis of Middle Devonian Marcellus shale in northern West Virginia, USA, Master's thesis, West Virginia University, 385p.

Phan, T.T, A.N. Paukert Vankeuren, and J.A. Hakala, 2018, Role of water-rock interaction in the geochemical evolution of Marcellus Shale produced waters: International Journal of Coal Geology, v. 191, p. 95-111, https://doi.org/10.1016/j.coal.2018.02.014 
Phan, T.T., J.A. Hakala, and S. Sharma, 2020, Application of isotopic and geochemical signals in unconventional oil and gas reservoir produced waters toward characterizing in situ geochemical fluid-shale reactions: Science of the Total Environment, v. 714: 136867. https://doi.org/10.1016/j.scitotenv.2020.136867.

Pilewski, J, S. Sharma, V. Agrawal, J.A. Hakala, and M.Y. Stuckman, 2019, Effects of maturity and mineralogy on fluid-rock reactions in the Marcellus Shale: Environmental Science. Processes \& Impacts, v. 21, p. 845-855. https://doi.org/10.1039/C8EM00452H

Rowan, E. L., 2006, Burial and thermal history of the central Appalachian Basin, based on three 2-D models of Ohio, Pennsylvania, and West Virginia, USGS Open-File Report 20061019, 35p. https://doi.org/10.3133/ofr20061019

Rowan, E.L., M.A. Engle, T.F. Kraemer, K.T. Schroeder, R.W. Hammack, and M.W. Doughten, 2015, Geochemical and isotopic evolution of water produced from Middle Devonian Marcellus shale gas wells, Appalachian basin, Pennsylvania: AAPG Bulletin, v. 99, no. 2, p. 181-206. doi: https://doi.org/10.1306/07071413146

Roychaudhuri, B., T.T. Tsotsis, and K. Jessen, 2013, An experimental investigation of spontaneous imbibition in gas shales: Journal of Petroleum Science and Engineering, v. 111, p. 87-97. https://doi.org/10.1016/j.petrol.2013.10.002

Schmoker, J.A., 1979, Determination of organic content of Appalachian Devonian Shales from formation density logs: AAPG Bulletin, v. 63, no. 9, p. 1504-1537. https://doi.org/10.1306/2F9185D1-16CE-11D7-8645000102C1865D

Schmoker, J.A., 1981, Determination of organic content of Appalachian Devonian Shales from gamma-ray logs: AAPG Bulletin, v.65, no.7, p.1285-1298. https://doi.org/10.1306/03B5949A-16D1-11D7-8645000102C1865D

Schmoker, J.A., 1993, Use of formation-density logs to determine organic-carbon content in Devonian shales of the western Appalachian Basin and an additional example based on the Bakken formation of the Williston Basin: United States Geological Survey Bulletin, 1909 p. J1 - J14

Sharma, S., V. Agrawal, R. Akondi, Y. Wang, and A. Hakala, 2021, Understanding controls on the geochemistry of hydrocarbon produced waters from different basins across the US: Environmental Science: Processes \& Impacts, v. 23, p. 28-47. https://doi.org/10.1039/D0EM00388C

U.S EIA, 2021. Natural Gas. Natural Gas Weekly Update - February 4, 2021. Accessed $2 / 5 / 2021$

U.S EIA, 2019. Today in Energy. United States has been a net exporter of natural gas for more than 12 consecutive months - May 2, 2019. Accessed 2/1/2020 
Wang, G. and T.C. Carr, 2012, Methodology of organic-rich shale lithofacies identification and prediction: A case study from Marcellus Sale in the Appalachian basin: Computers and Geosciences, v. 49, p. 151 - 163. https://doi.org/10.1016/j.cageo.2012.07.011

Wilkins S., V. Mount., K. Mahon, A. Perry, and J. Koenig, 2014, Characterization and development of subsurface fractures observed in the Marcellus Formation, Appalachian Plateau, north-central Pennsylvania: AAPG Bulletin, 98(11), p.2301-2345. https://doi.org/10.1306/08191414024

Zagorski, W. A., G.R. Wrightstone, and D.C. Bowman, 2012, The Appalachian basin Marcellus gas play: Its history of development, geologic controls on production, and future potential as a world-class reservoir, in J. A. Breyer, ed., Shale reservoirs: Giant resources for the $21^{\text {st }}$ century: AAPG Memoir 97, p. 172-200. https://doi.org/10.1306/13321465M973491

Zagorski, W. A., M. Emery, and J.L. Ventura, 2017, The Marcellus Shale Play: Its Discovery and Emergence as a Major Global Hydrocarbon Accumulation, in R. K. Merrill and C. A. Sternbach, eds., Giant fields of the decade 2000-2010: AAPG Memoir 113, p. 55-90. https://doi.org/10.1306/13572001M1133491

Ziemkiewicz, P. F., 2017, The Marcellus Shale Energy and Environmental Laboratory (MSEEL): Water and Solid Waste Findings - Year One. Unconventional Resources Technology Conference. https://doi.org/10.15530/URTEC-2017-2669914 


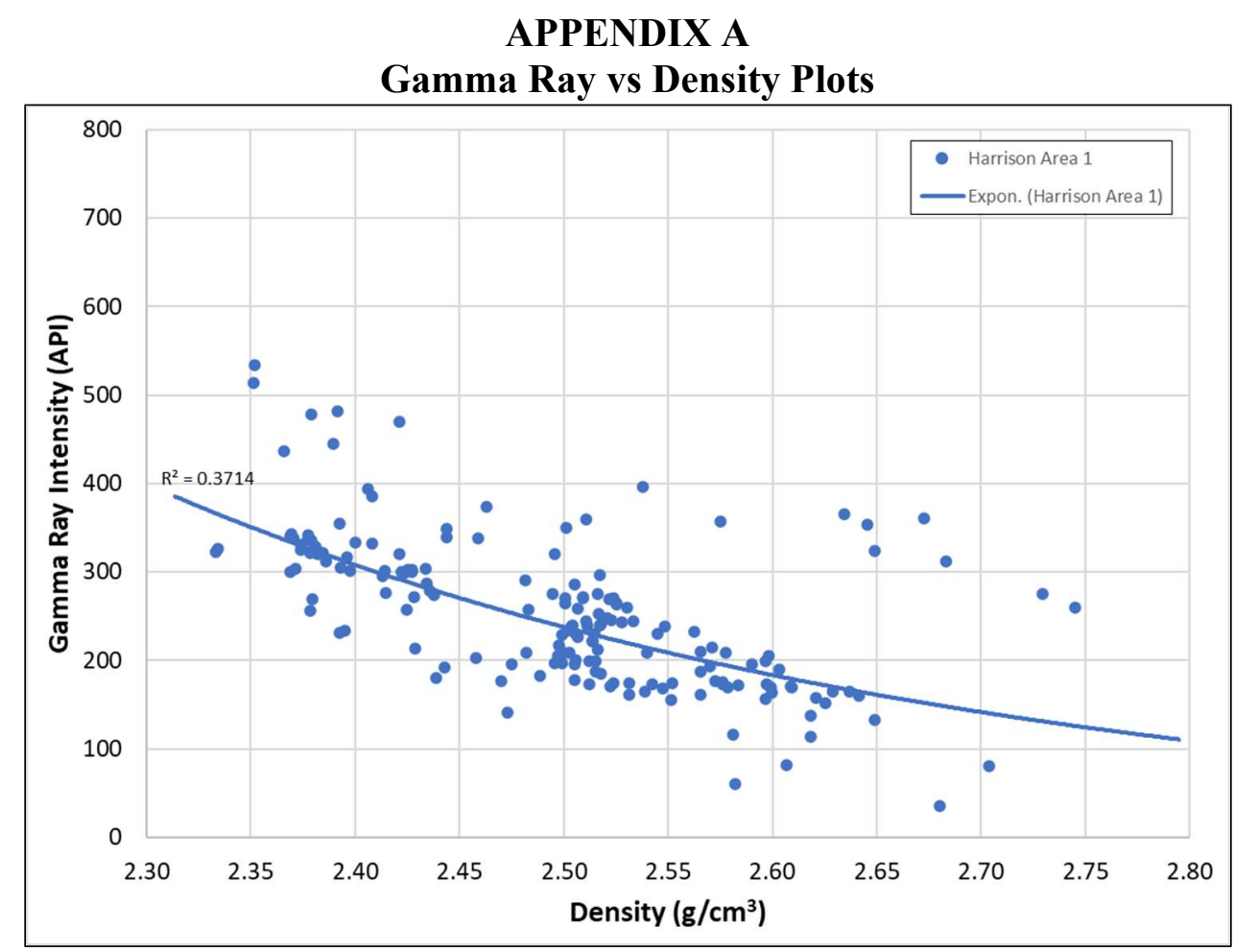

Figure A-1 - Relationship between gamma-ray intensity and density in the Marcellus Shale for Harrison Area 1. Trendlines indicate that there is a general agreement among the data showing that as gamma-ray increases, density generally decreases.

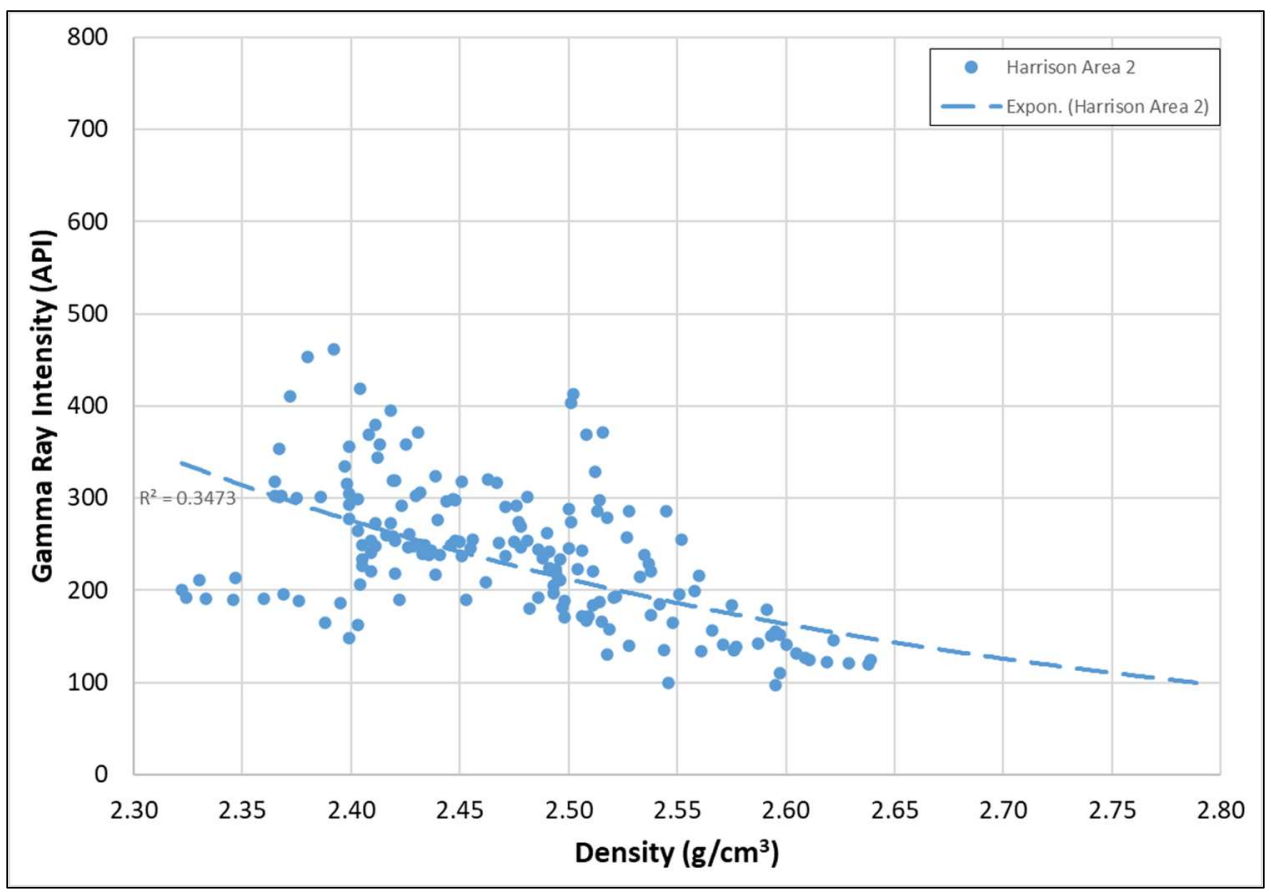

Figure A-2 - Relationship between gamma-ray intensity and density in the Marcellus Shale for Harrison Area 2. Trendlines indicate that there is a general agreement among the data showing that as gamma-ray increases, density generally decreases. 


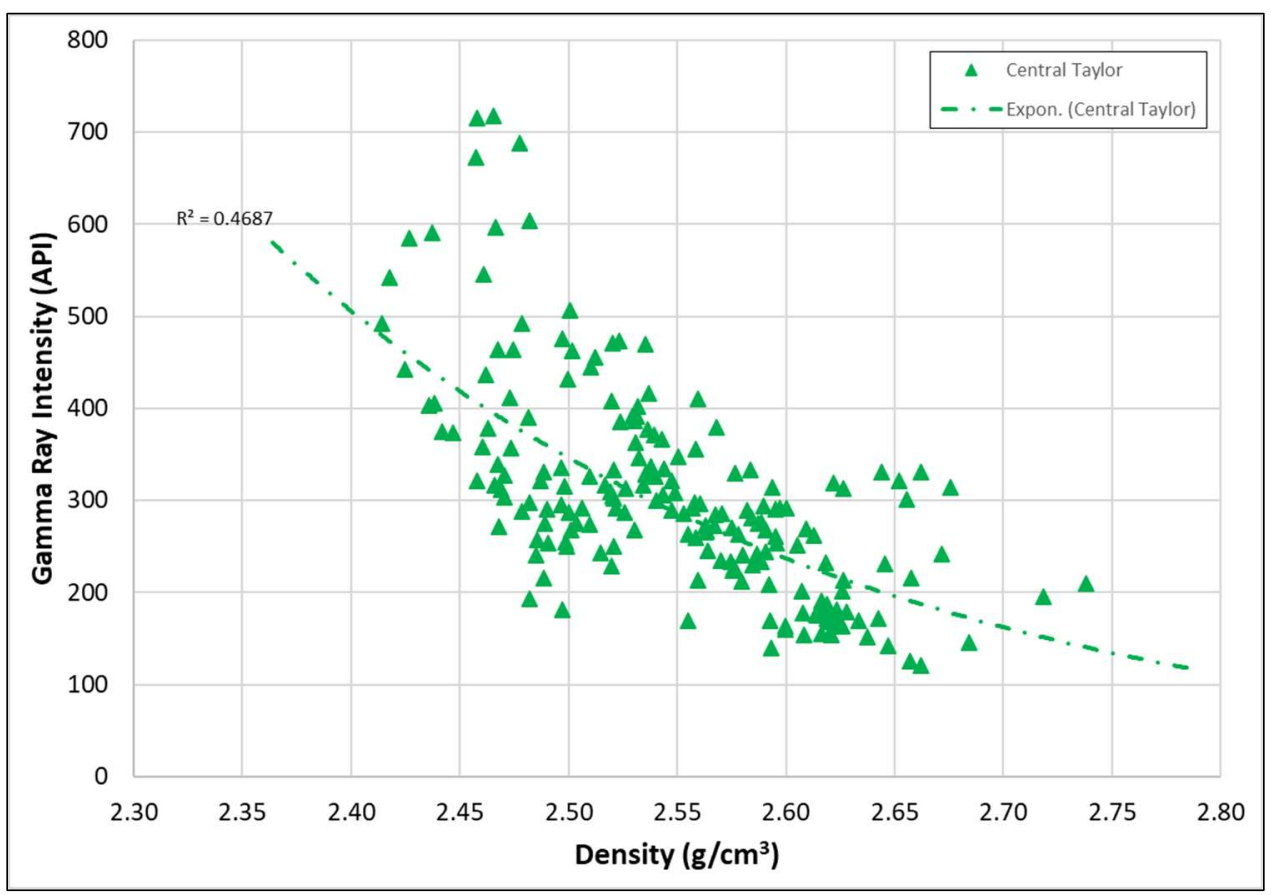

Figure A-3 - Relationship between gamma-ray intensity and density in the Marcellus Shale for the Central Taylor Area. Trendlines indicate that there is a general agreement among the data showing that as gamma-ray increases, density generally decreases.

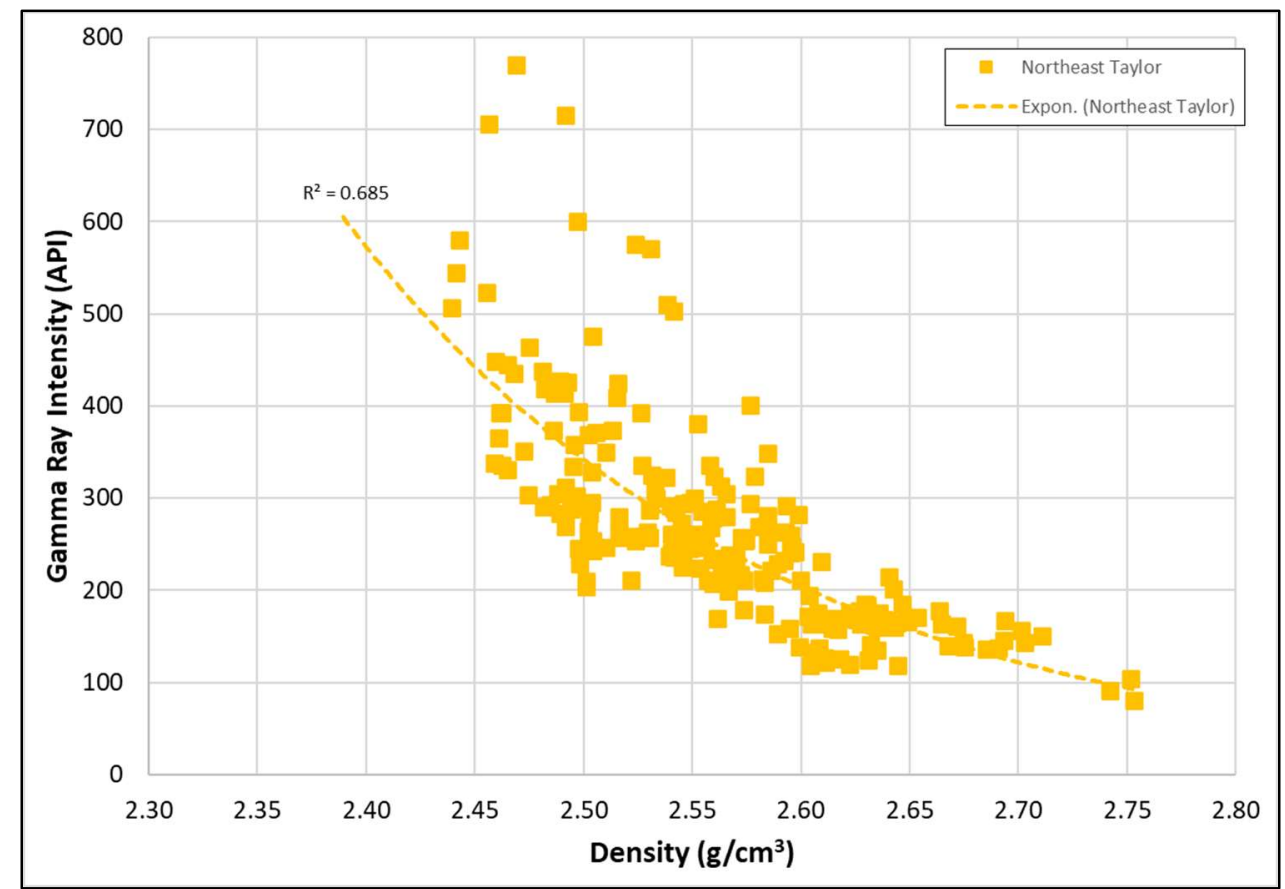

Figure A-4-Relationship between gamma-ray intensity and density in the Marcellus Shale for the Northeast Taylor Area. Trendlines indicate that there is a general agreement among the data showing that as gamma-ray increases, density generally decreases. 


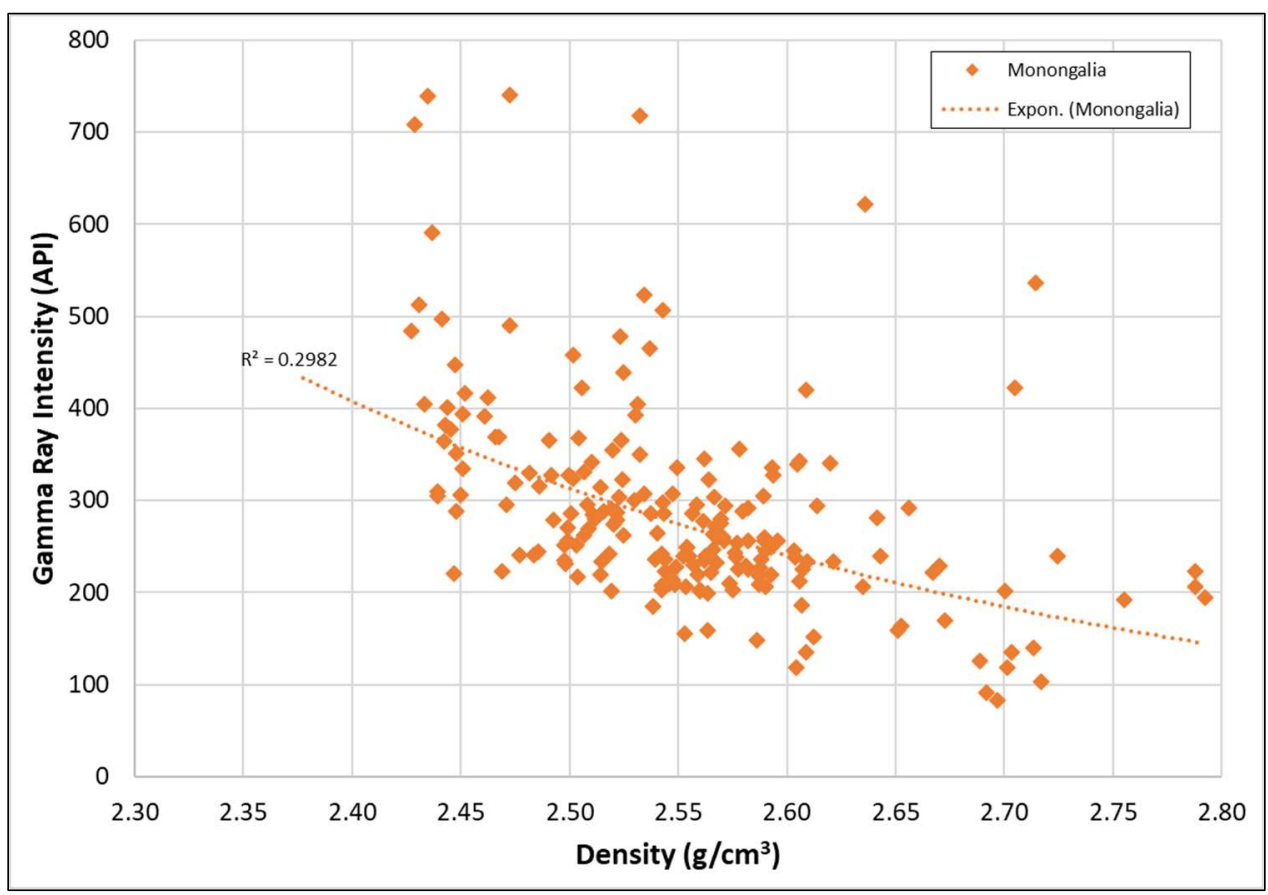

Figure A-5 - Relationship between gamma-ray intensity and density in the Marcellus Shale for the Monongalia Area. Trendlines indicate that there is a general agreement among the data showing that as gamma-ray increases, density generally decreases.

\section{Gamma Ray vs. Pyrolysis and Log-calculated TOC Plots}

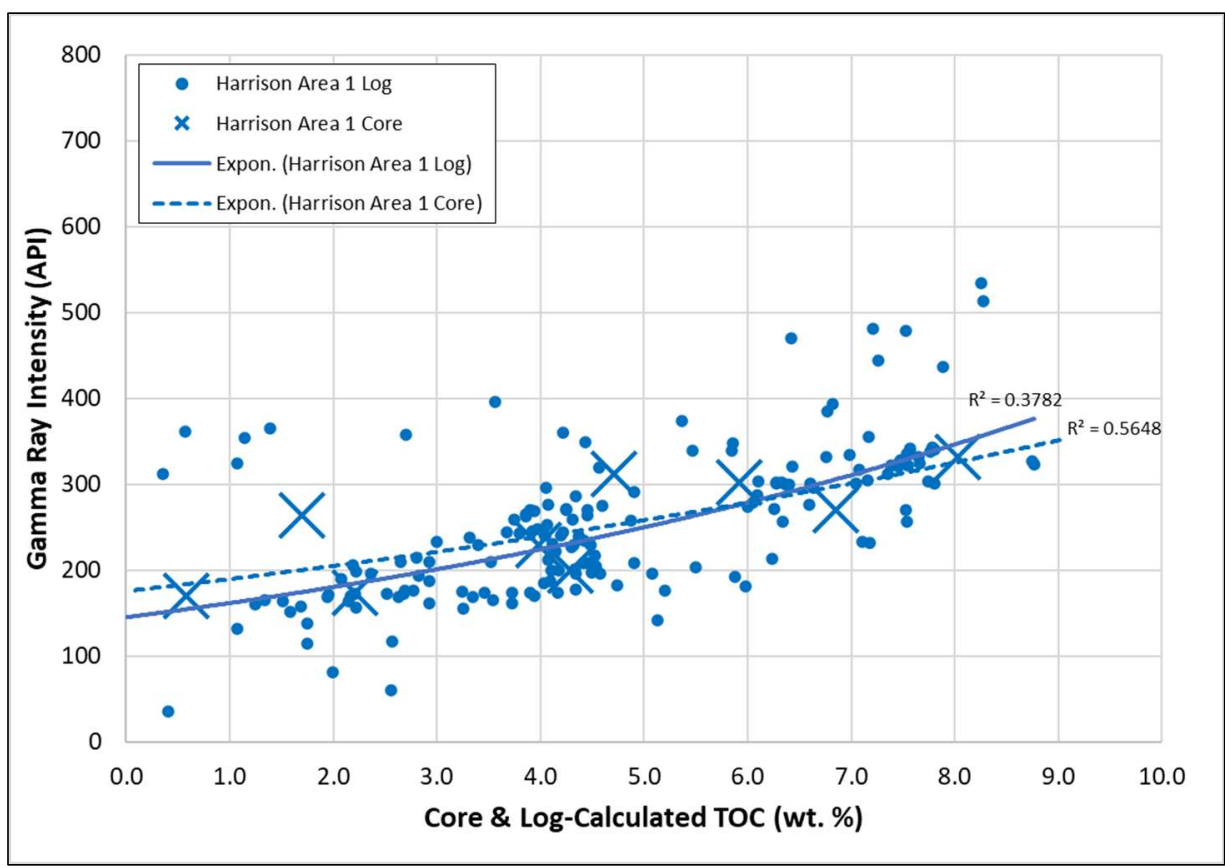

Figure A-6 - Relationship between core-obtained TOC, log-calculated TOC and gamma-ray values in the Marcellus Shale for the core located in Harrison Area 1. Trendlines indicate that there is a general agreement among the data showing that as gamma-ray increases, TOC values generally increase. 


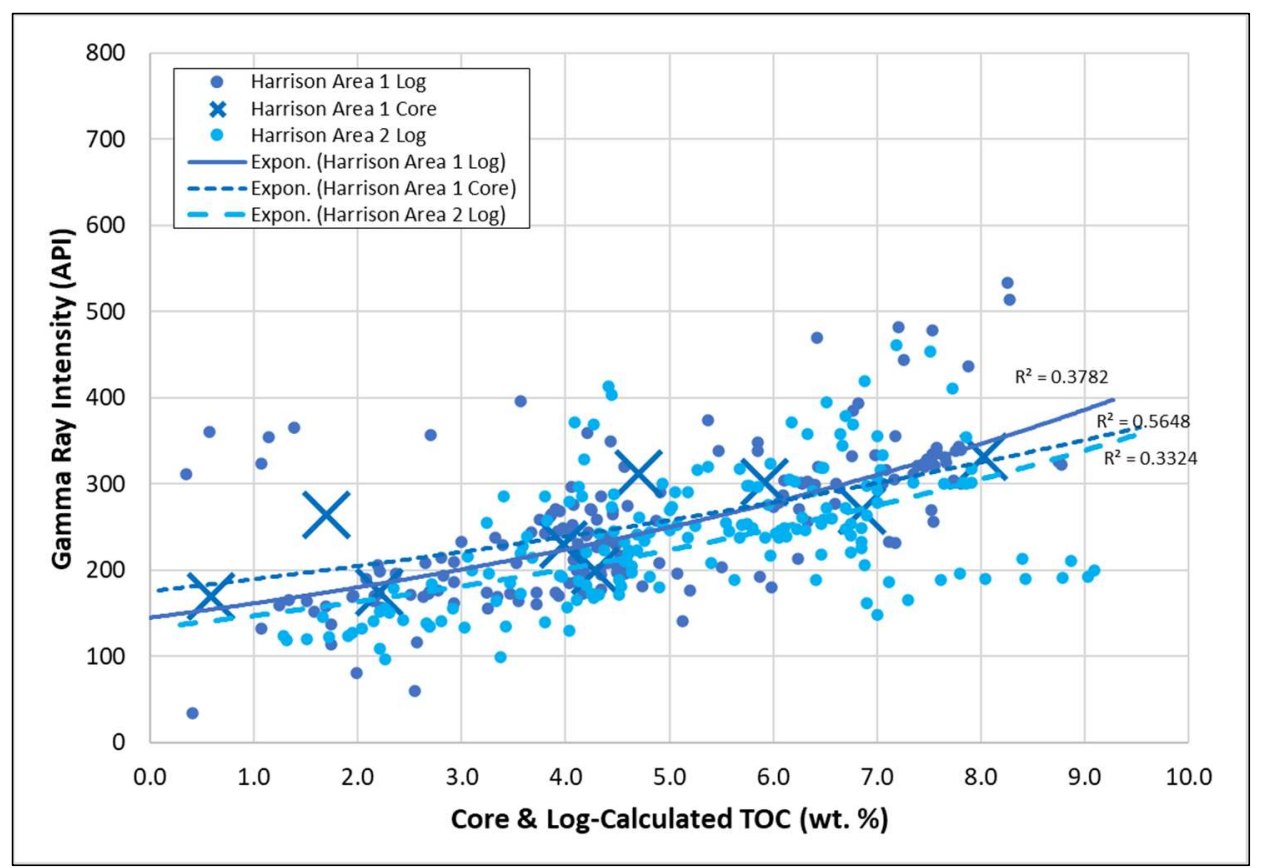

Figure A-7-Relationship between core-obtained TOC, log-calculated TOC and gamma-ray values in the Marcellus Shale for Harrison Area 1 and Harrison Area 2. Trendlines indicate that both areas share similar characteristics. There is a general agreement among the data showing that as gamma-ray increases, TOC values generally increase.

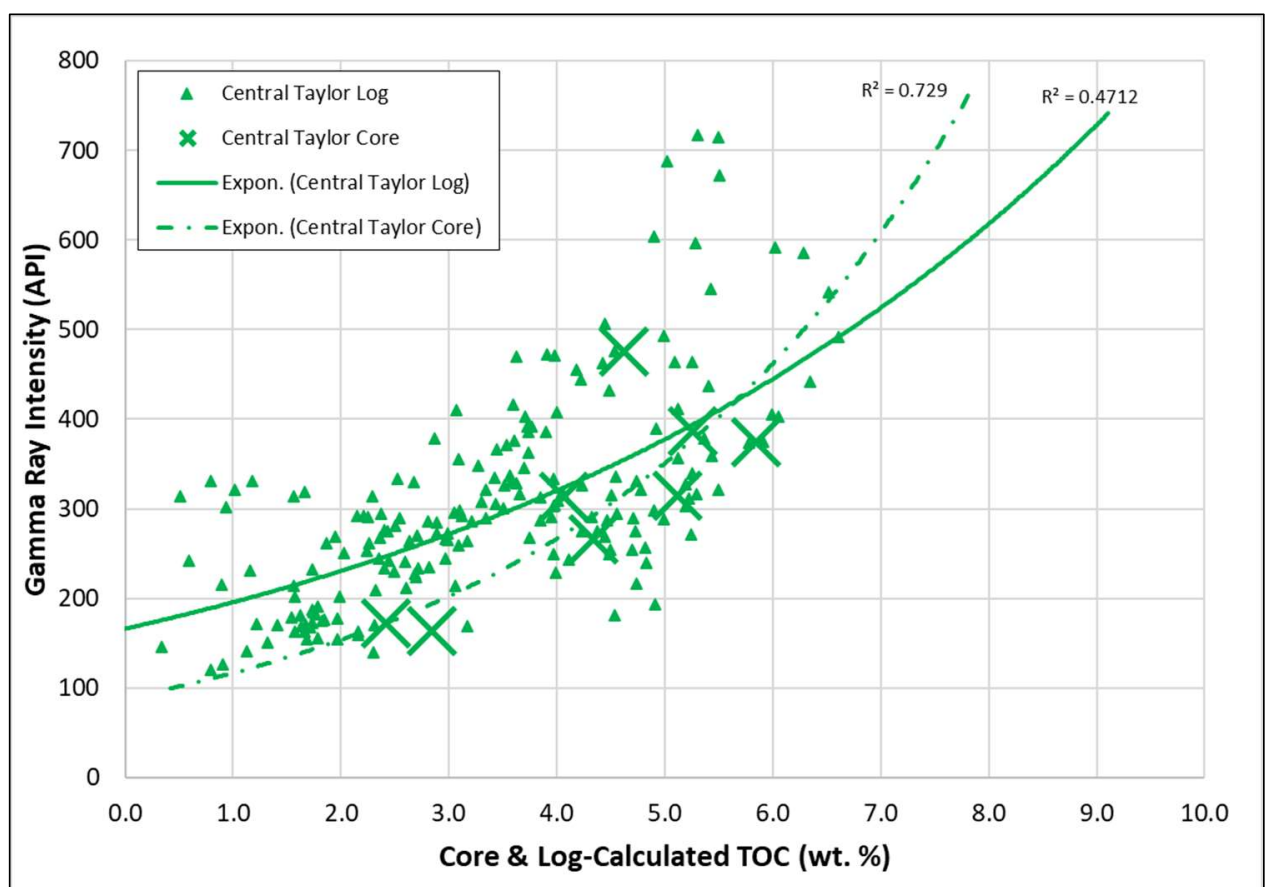

Figure A-8 - Relationship between core-obtained TOC, log-calculated TOC and gamma-ray values in the Marcellus Shale for the core located in the Central Taylor Area. Trendlines indicate that there is a general agreement among the data showing that as gamma-ray increases, TOC values generally increase. 


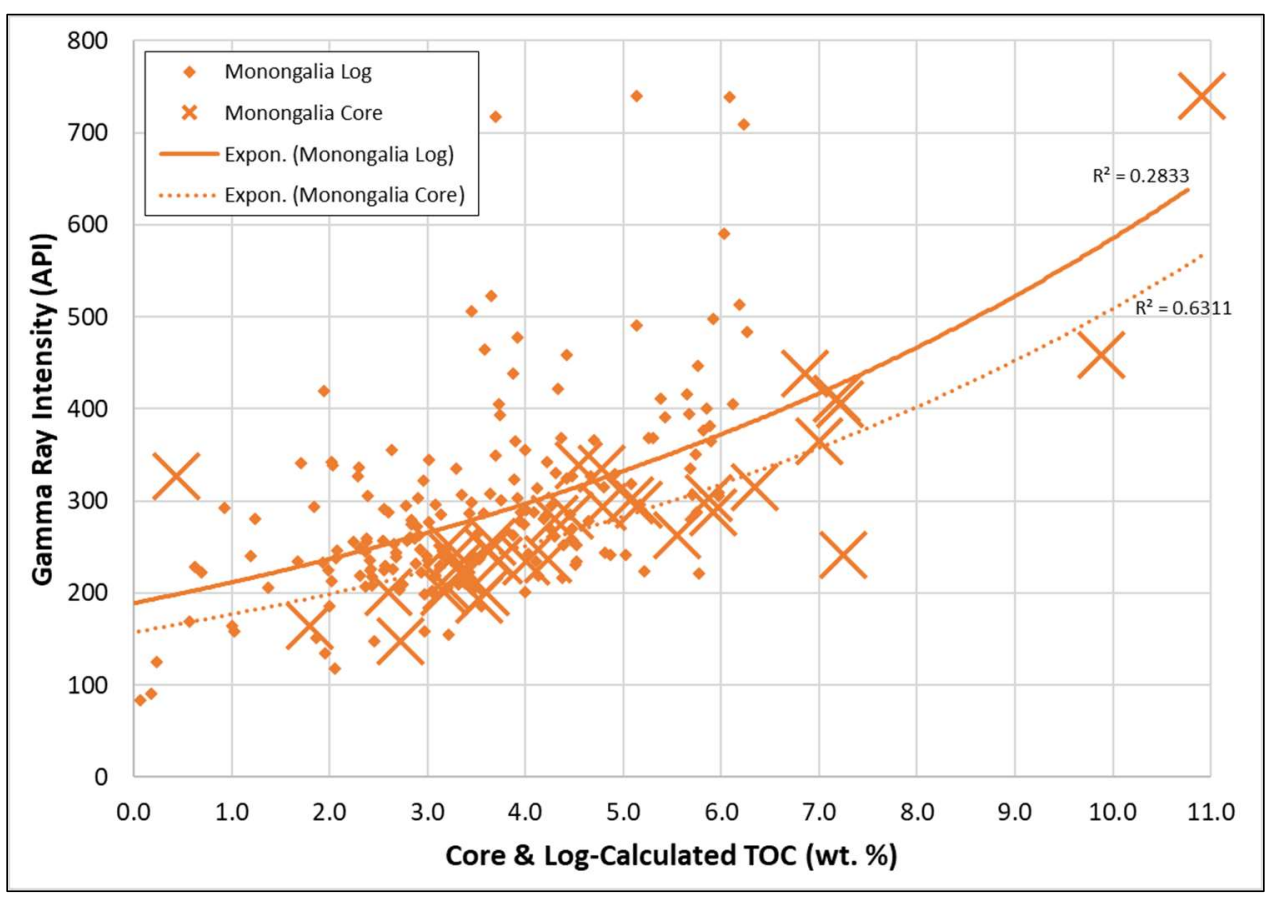

Figure A-9 - Relationship between core-obtained TOC, log-calculated TOC and gamma-ray values in the Marcellus Shale for the core located in the Monongalia Area. Trendlines indicate that there is a general agreement among the data showing that as gamma-ray increases, TOC values generally increase.

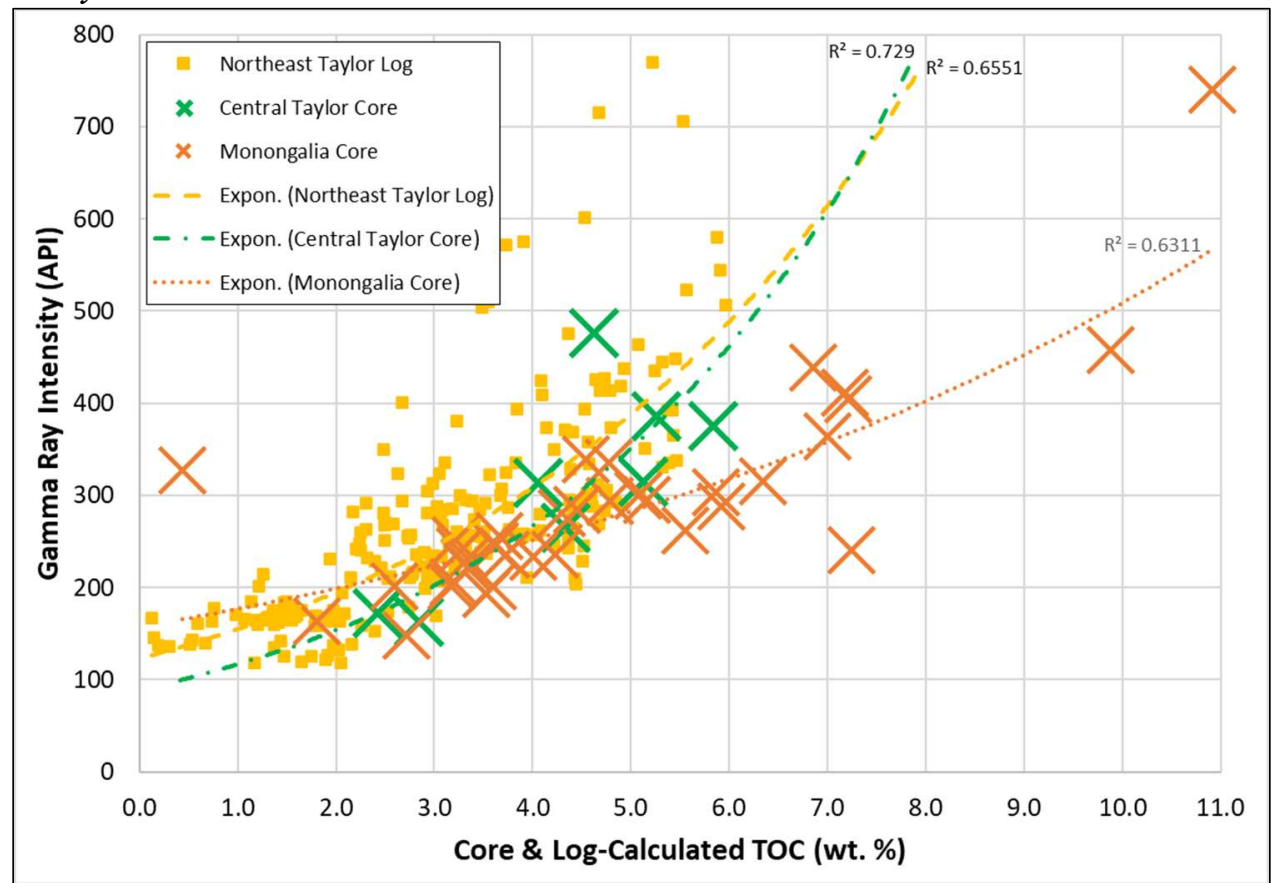

Figure A-10 - Relationship between core-obtained TOC for the Central Taylor and Monongalia areas, log-calculated TOC for the Northeast Taylor Area and gamma-ray values in the Marcellus Shale. Trendlines indicate that log-calculated TOC values for Northeast Taylor compare reasonably well with the core-obtained values from the Central Taylor Area. There is a general agreement among the data showing that as gamma-ray increases, TOC values generally increase. 


\section{APPENDIX B \\ Daily Cumulative Percentage Fluid Recovery by Area}

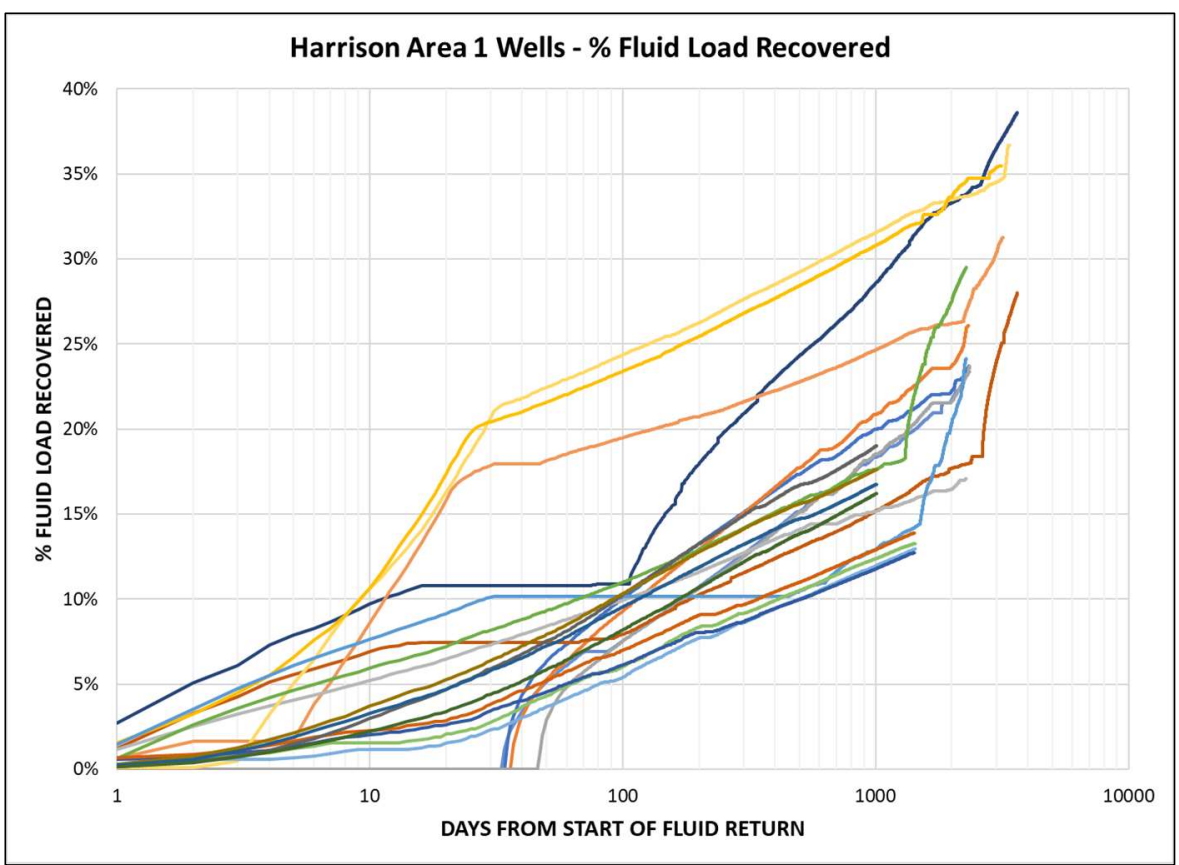

Figure B-1 - Fluid retuned for Harrison Area 1 normalized to the beginning of production. The 20 wells in this area have returned between $\sim 13 \%$ to $\sim 39 \%$ of the initial fluid load. Fluid return behaviors are variable across this area due to outside factors. Differences in returned fluid behavior are indicated by changes in line slope.

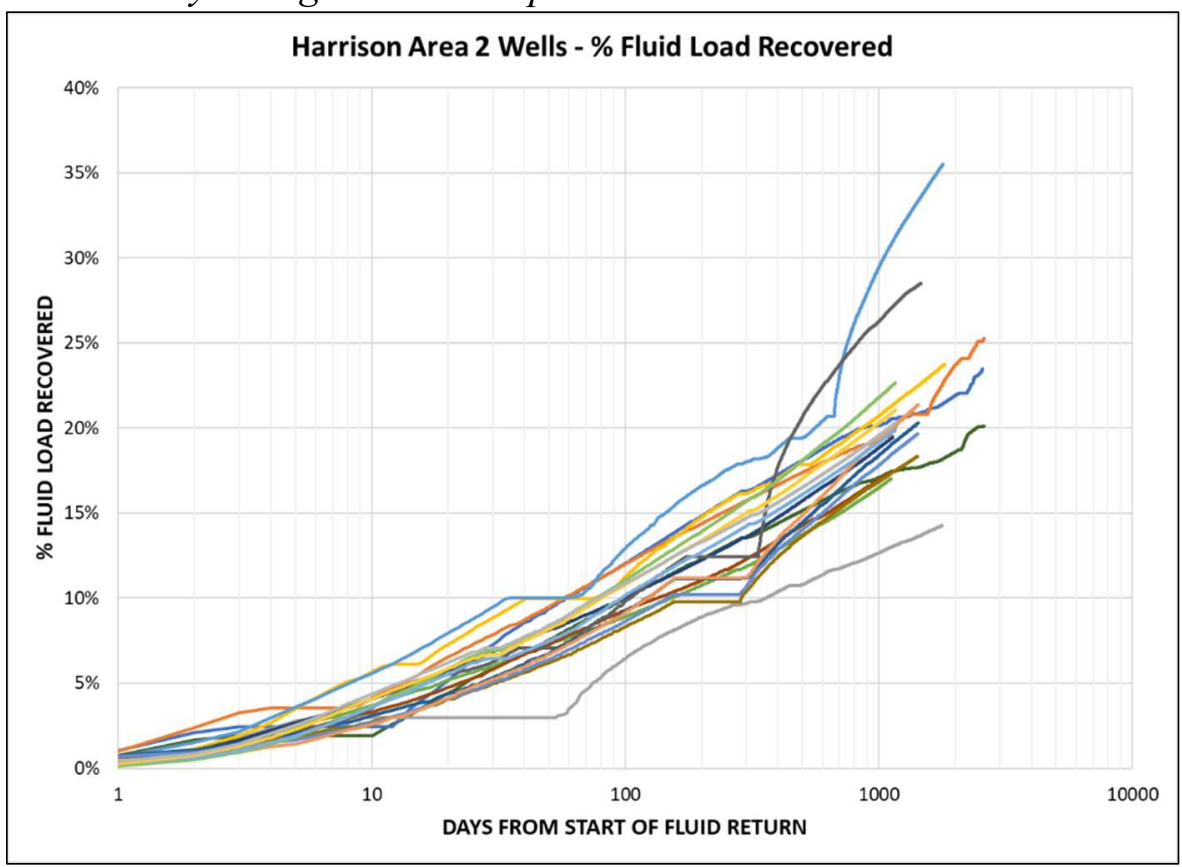

Figure B-2 - Fluid retuned for Harrison Area 2 normalized to the beginning of production. The 18 wells in this area have returned between $\sim 14 \%$ to $\sim 35 \%$ of the initial fluid load. Most wells in this area have a similar fluid return behavior. Differences in returned fluid behavior are indicated by changes in line slope. 


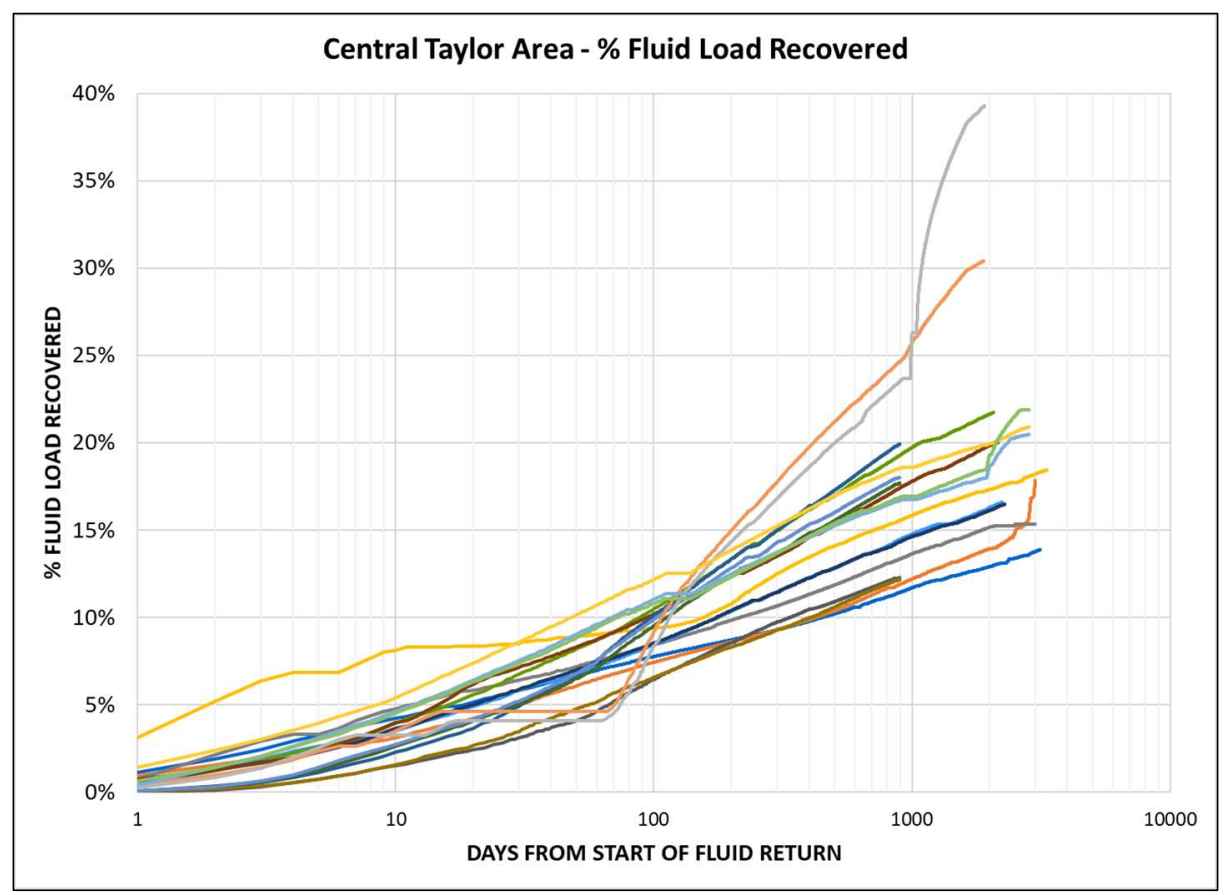

Figure B-3 - Fluid retuned for the Central Taylor Area normalized to the beginning of production. The 18 wells in this area have returned between $\sim 14 \%$ to $\sim 40 \%$ of the initial fluid load, representing the largest spread among the five area. Most wells in this area have a similar fluid return behavior with only two wells significantly different from the others. Differences in returned fluid behavior are indicated by changes in line slope.

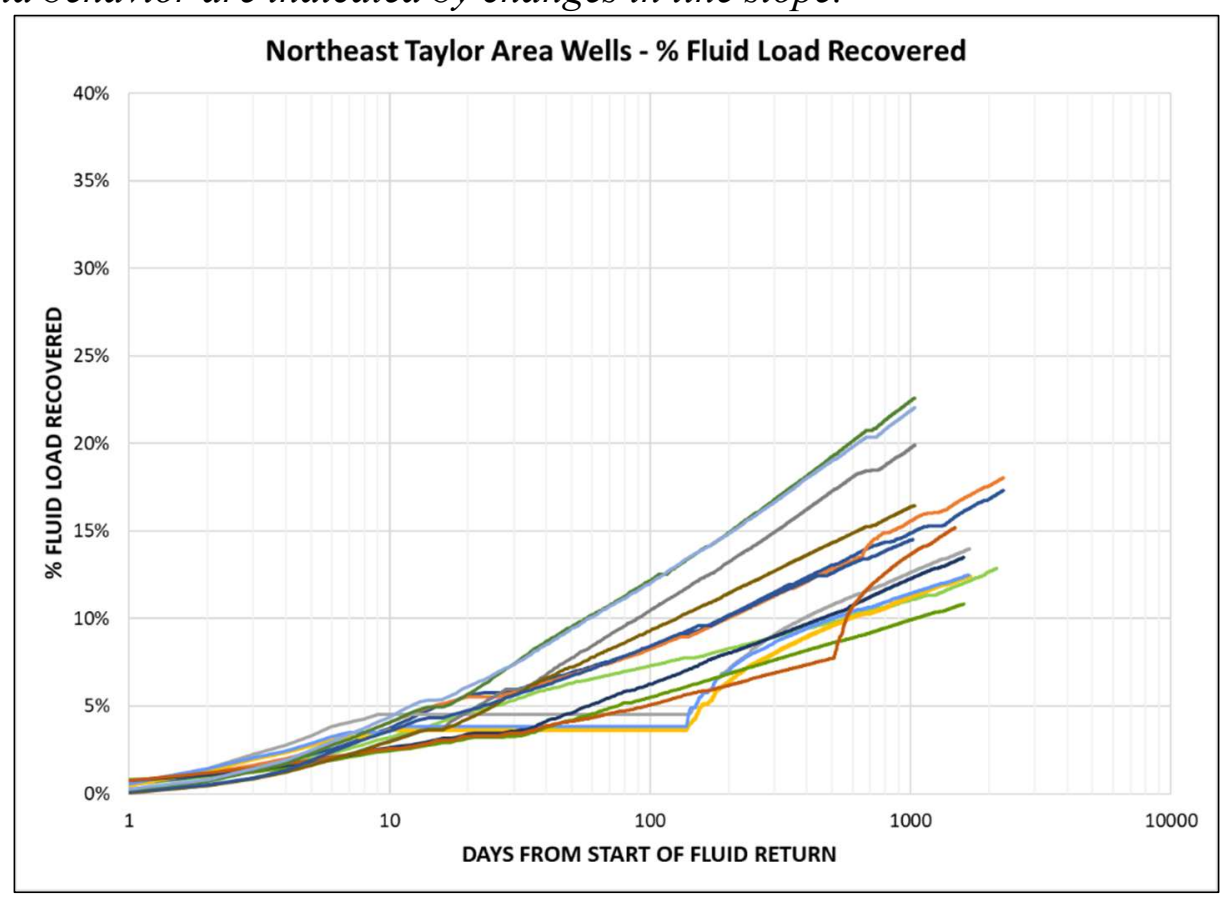

Figure B-4 - Fluid retuned for the Northeast Taylor Area normalized to the beginning of production. The 14 wells in this area have returned between $\sim 11 \%$ to $22 \%$ of the initial fluid load. Most wells in this area have a similar fluid return behavior with only a few wells retuning slightly more fluid than the other. Differences in returned fluid behavior are indicated by changes in line slope. 


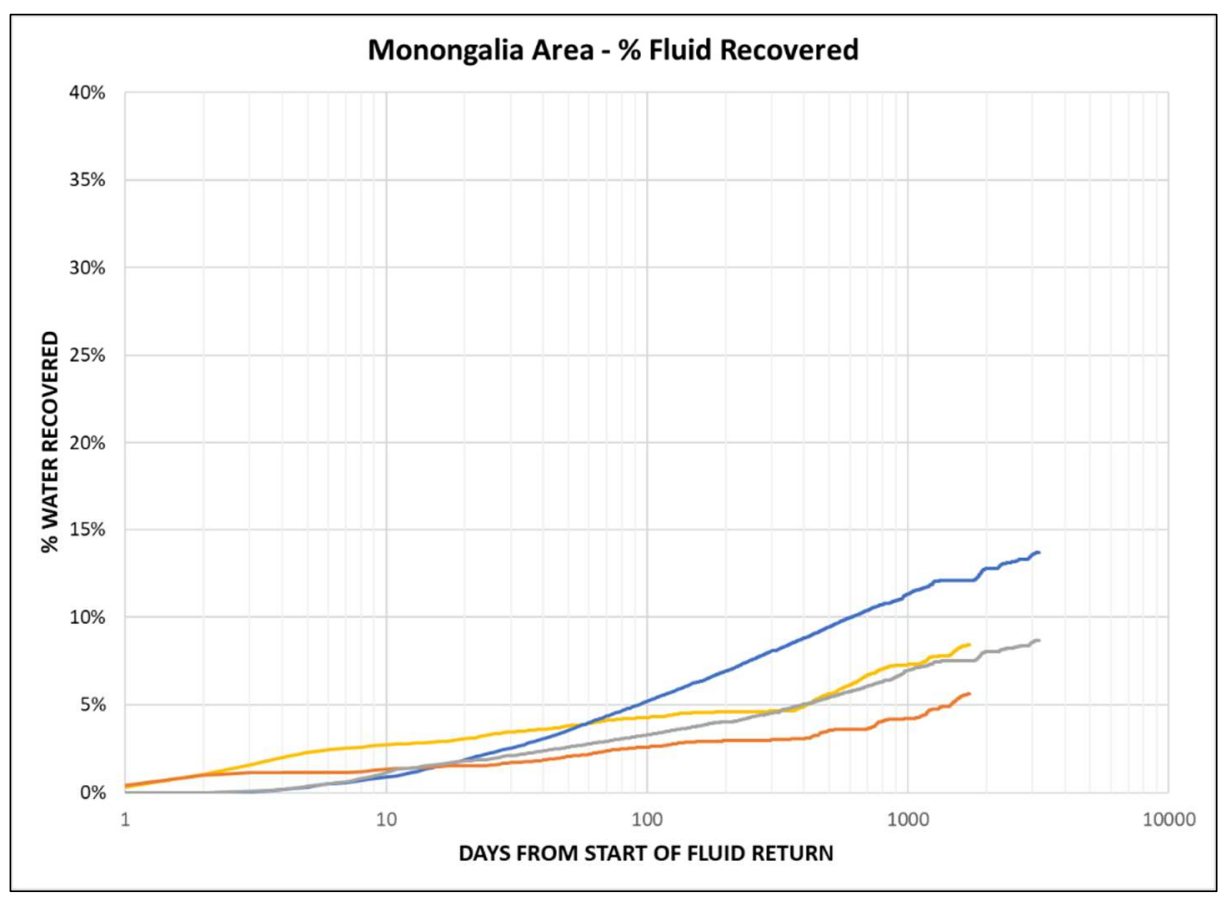

Figure B-5 - Fluid retuned for the Monongalia Area normalized to the beginning of production. The 4 wells in this area have returned between $\sim 5.5 \%$ to $\sim 14 \%$ of the initial fluid load. Only one well in this area is slightly higher than the other although not by a significant percentage ( 5\%). Differences in returned fluid behavior are indicated by changes in line slope. 


\section{APPENDIX C \\ Ion Concentration Plots}

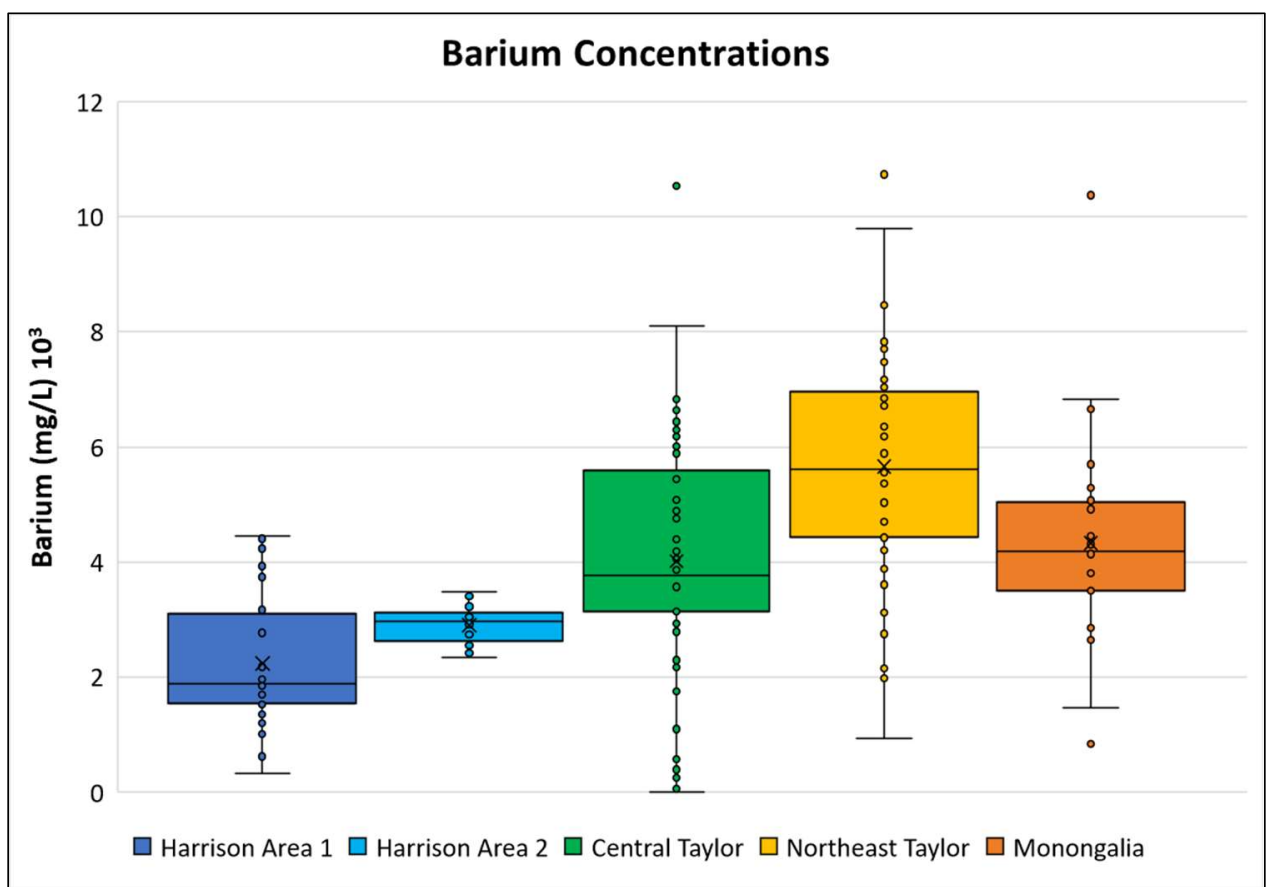

Figure $\mathbf{C}-1-B o x$ and whisker plot of barium concentrations across the five areas of the study. Harrison Areas 1 and 2 show similar values that are distinctively lower than the Central Taylor, Northeast Taylor, and Monongalia areas, which show similar values.

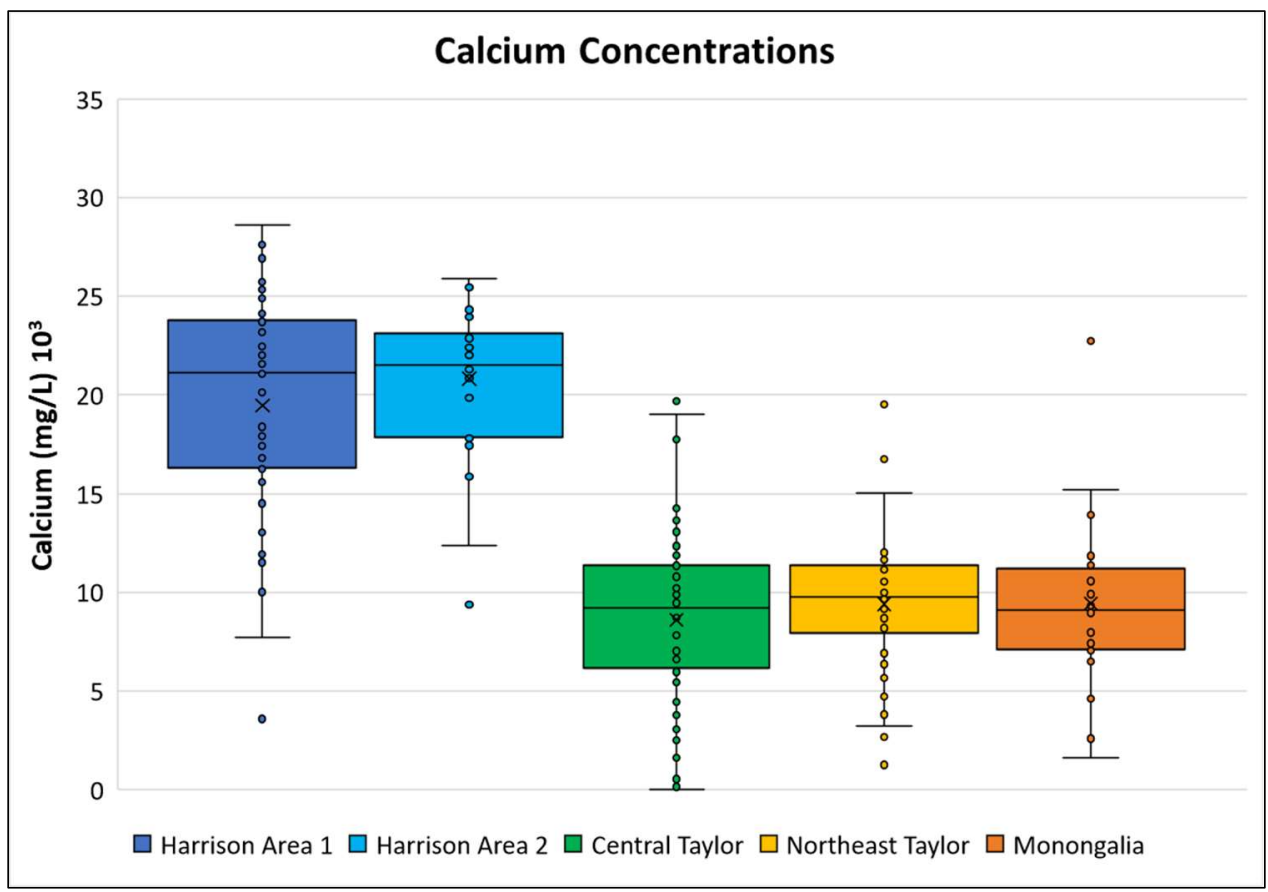

Figure C-2 - Box and whisker plot of calcium concentrations across the five areas of the study. Harrison Areas 1 and 2 show similar values that are distinctively higher than the Central Taylor, Northeast Taylor, and Monongalia areas, which show similar values. 


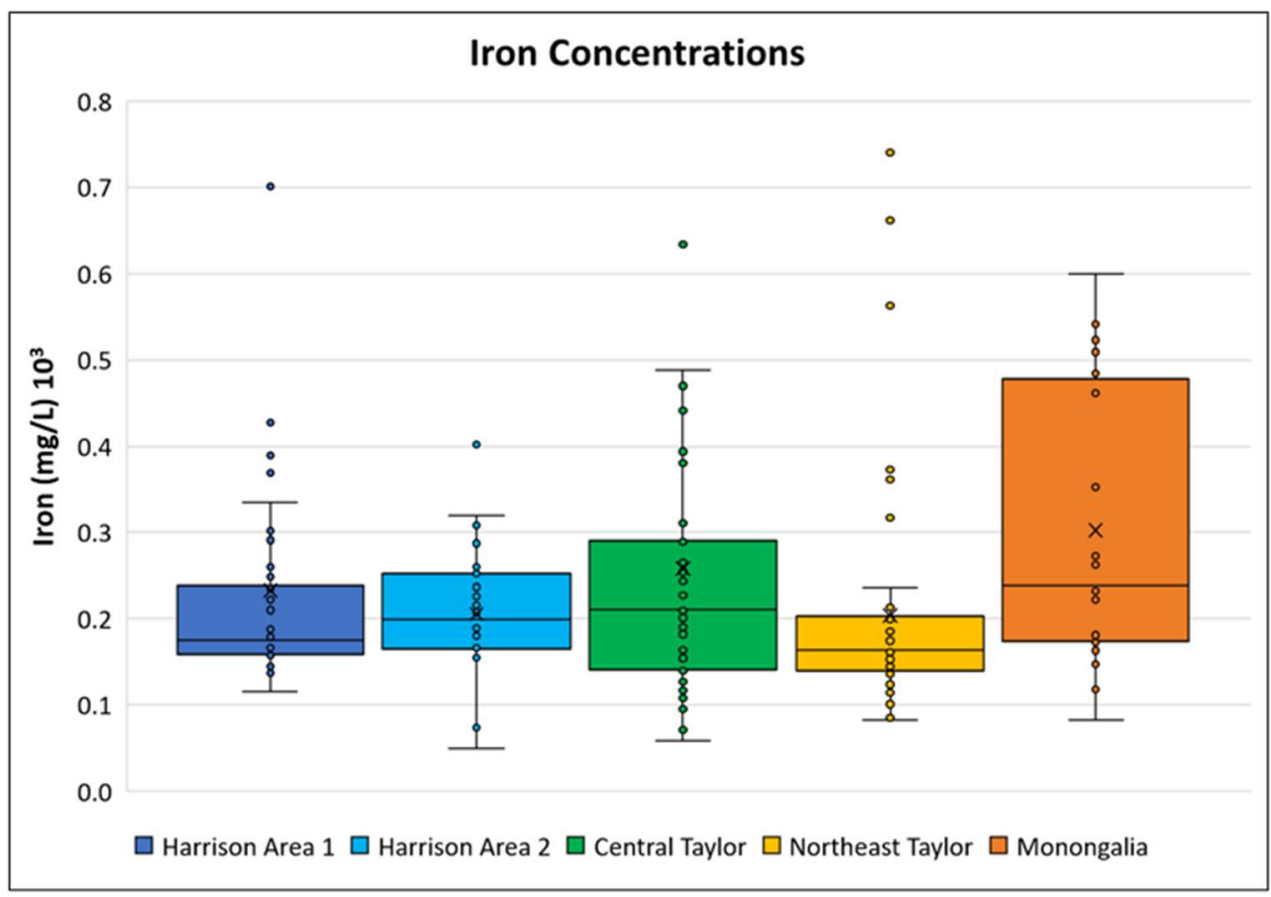

Figure C-3-Box and whisker plot of iron concentrations across the five areas of the study. All five areas show similar ranges and mean values.

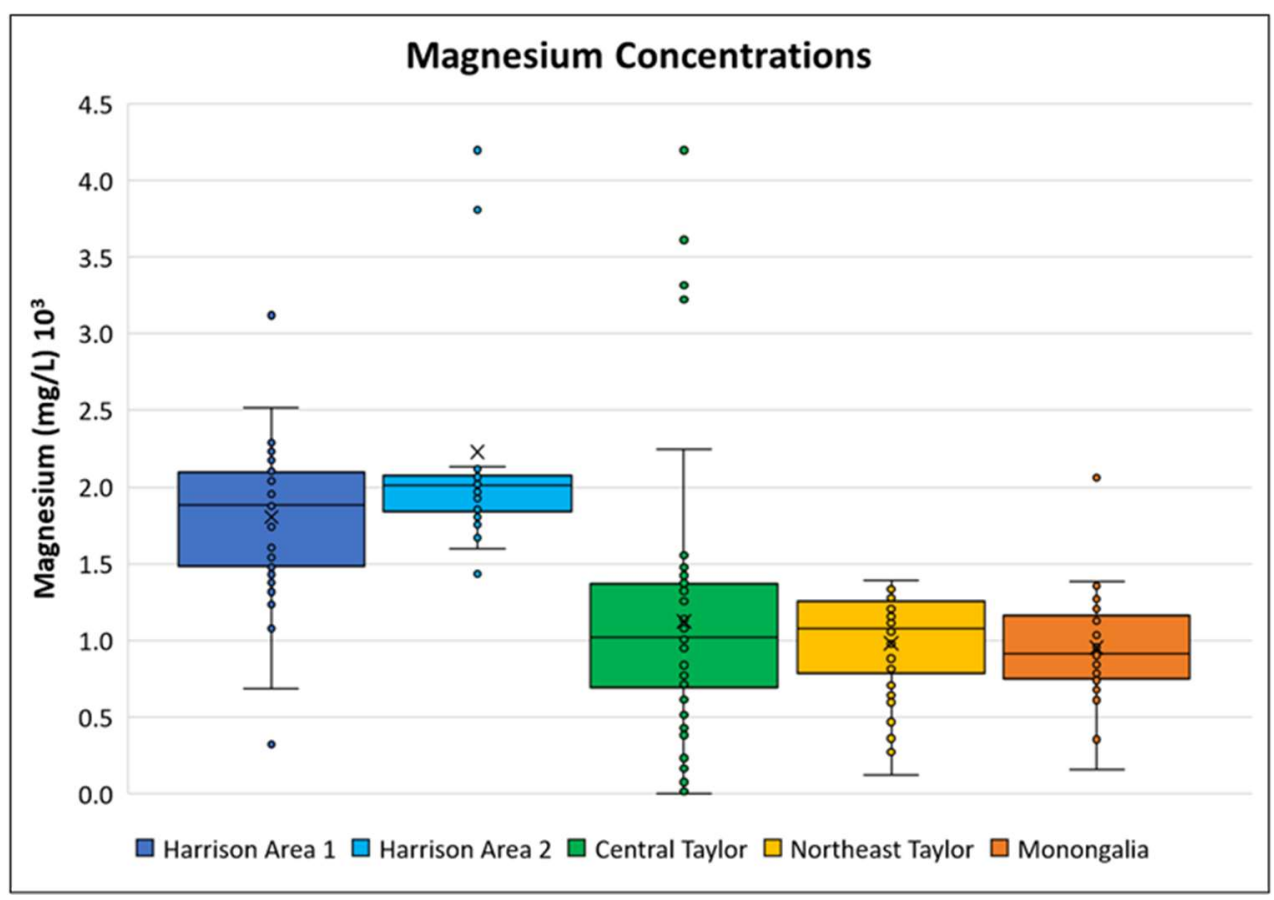

Figure C-4-Box and whisker plot of magnesium concentrations across the five areas of the study. Harrison Areas 1 and 2 show similar values that are distinctively higher than the Central Taylor, Northeast Taylor, and Monongalia areas, which show similar values. 


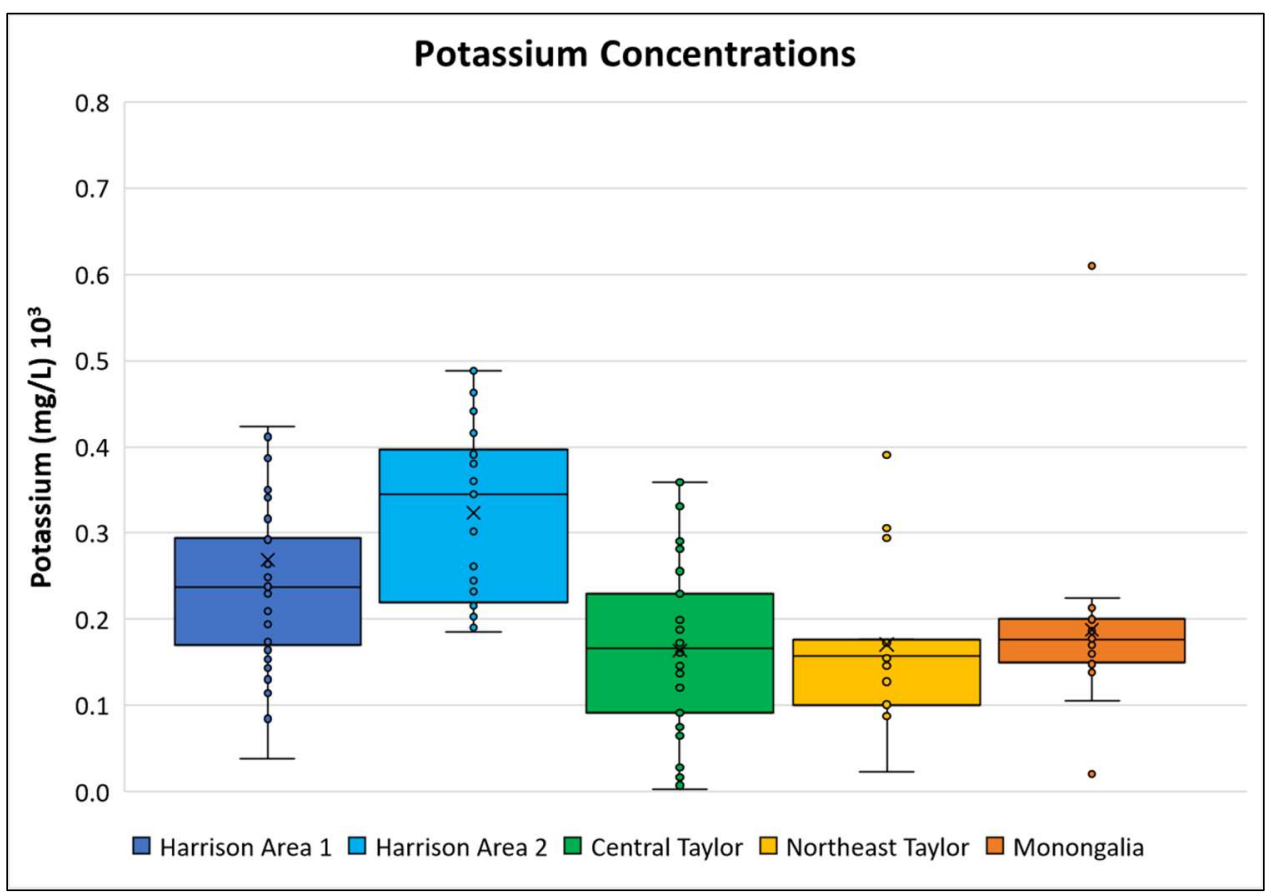

Figure C-5 - Box and whisker plot of potassium concentrations across the five areas of the study. Harrison Areas 1 and 2 show similar values that are slightly higher than the Central Taylor, Northeast Taylor, and Monongalia areas, which show similar values.

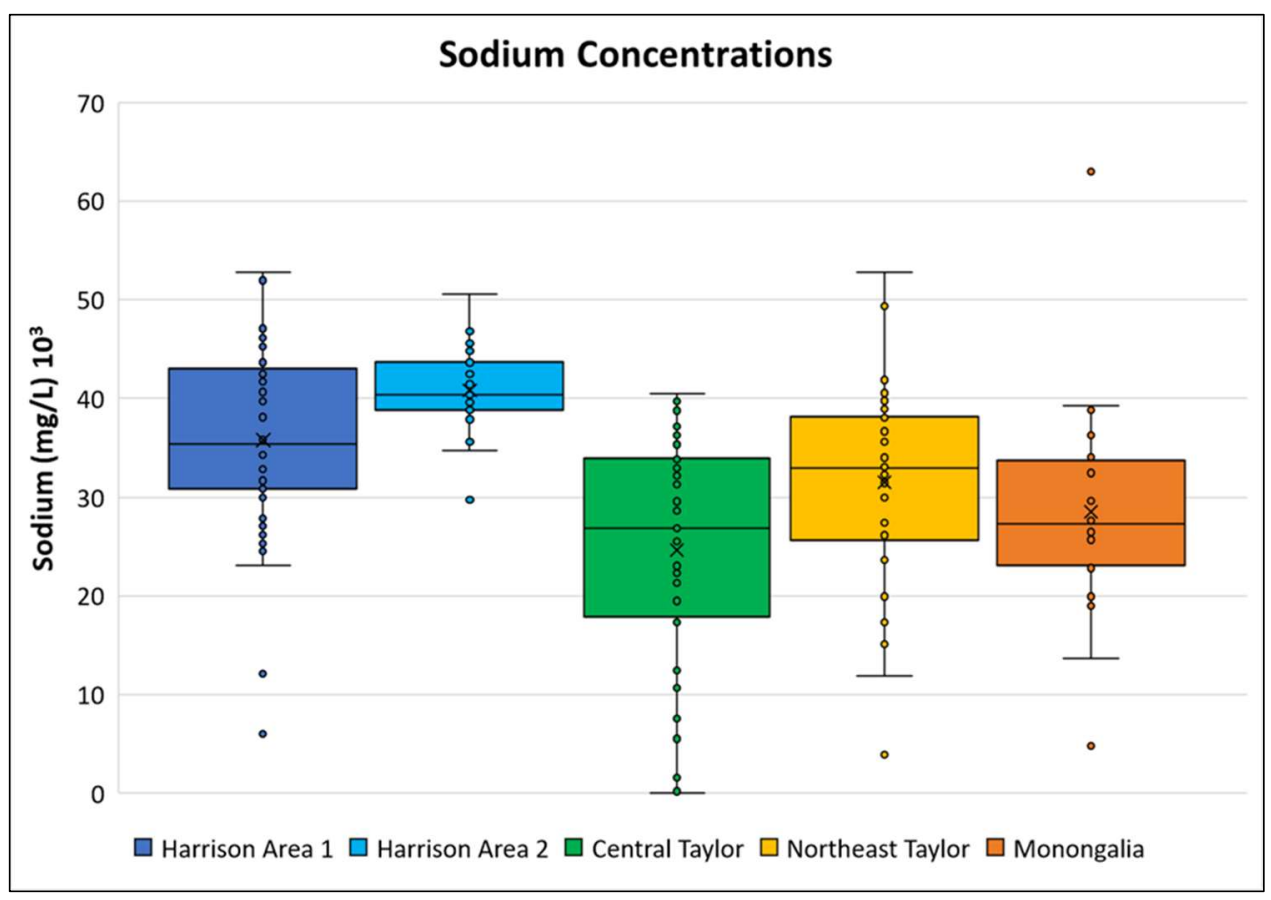

Figure C-6 - Box and whisker plot of sodium concentrations across the five areas of the study. Harrison Areas 1 and 2 show similar values that are slightly higher than the Central Taylor, Northeast Taylor, and Monongalia areas, which show similar values. 


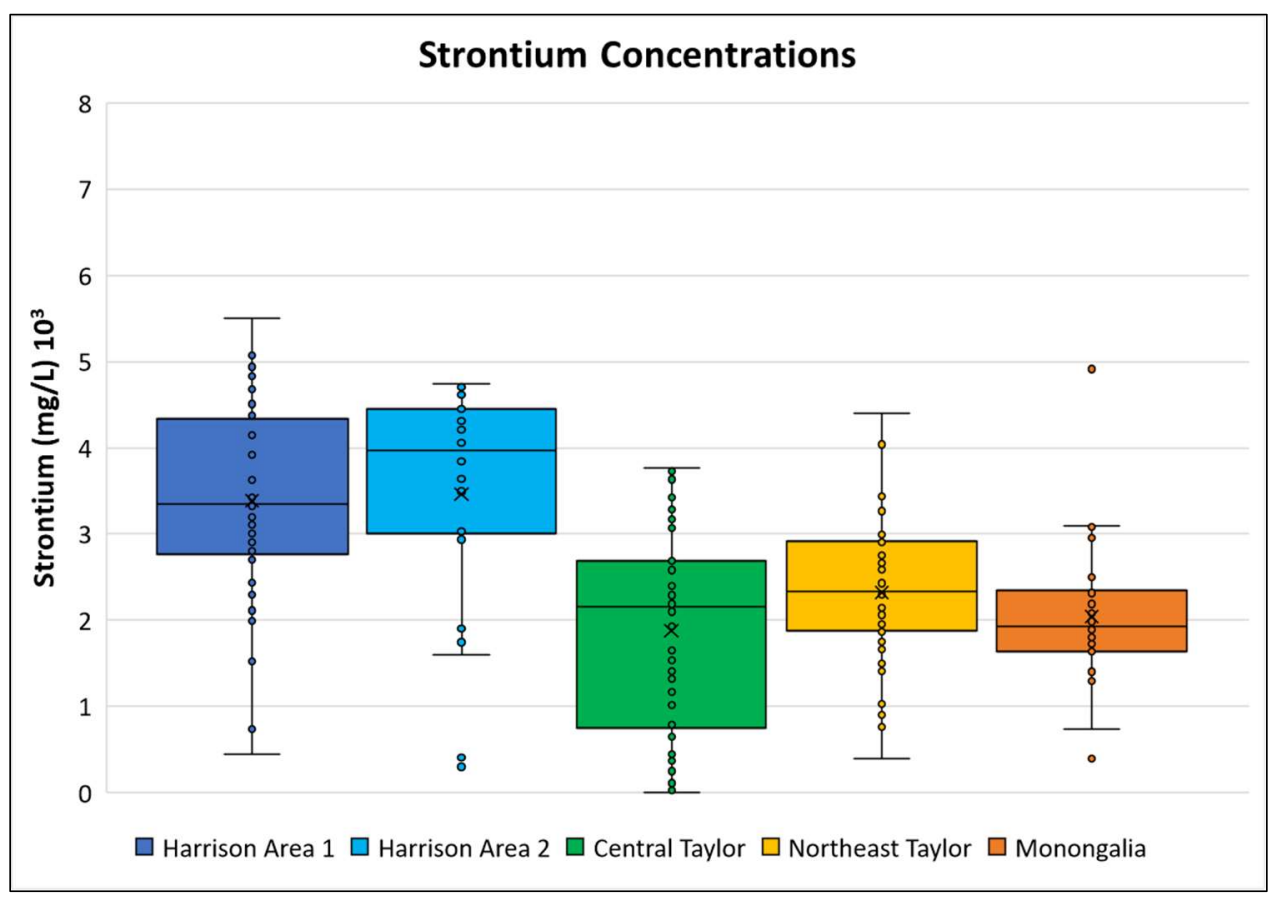

Figure C-7 - Box and whisker plot of strontium concentrations across the five areas of the study. Harrison Areas 1 and 2 show similar values that are distinctively higher than the Central Taylor, Northeast Taylor, and Monongalia areas, which show similar values.

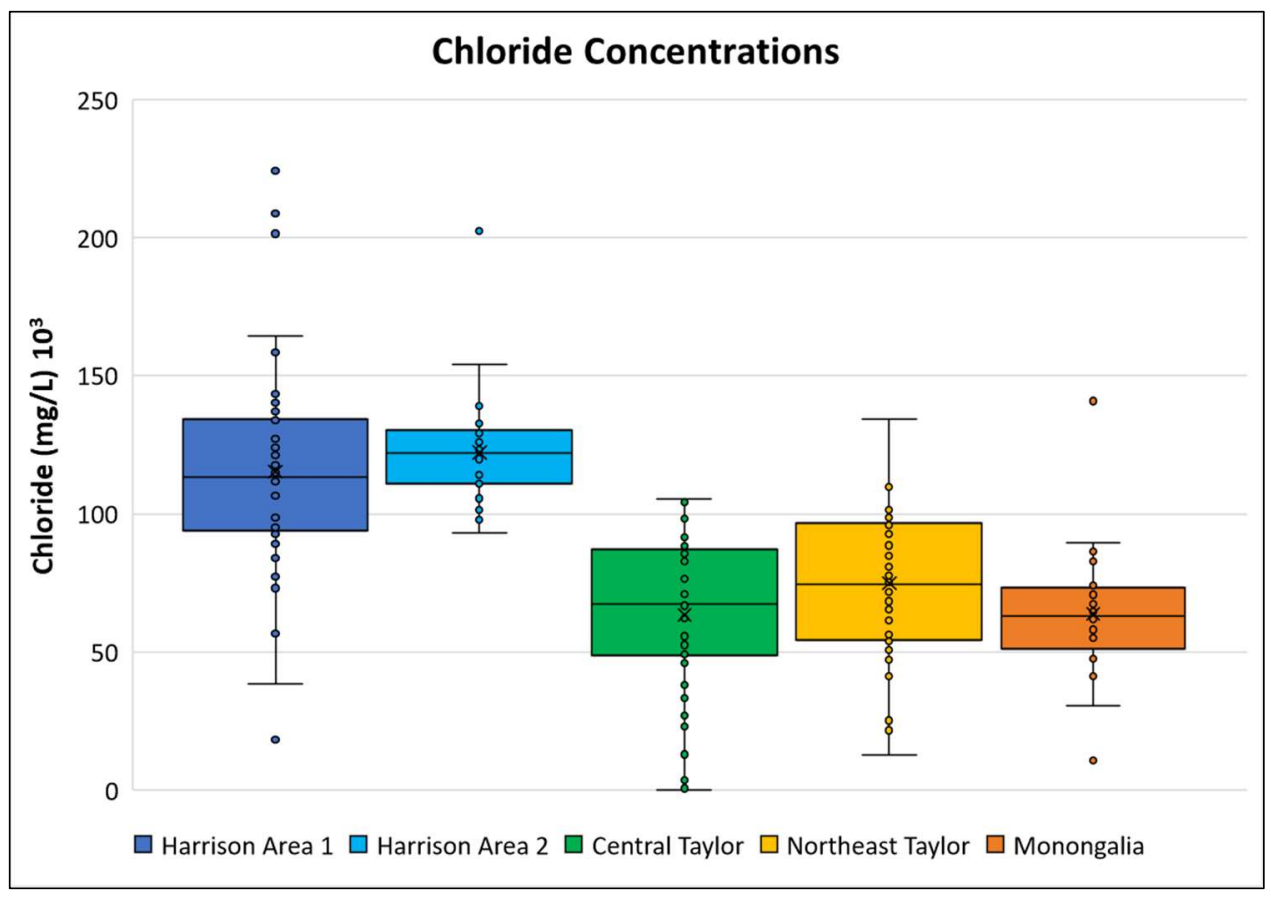

Figure $\mathbf{C - 8}$ - Box and whisker plot of chloride concentrations across the five areas of the study. Harrison Areas 1 and 2 show similar values that are distinctively higher than the Central Taylor, Northeast Taylor, and Monongalia areas, which show similar mean value 
APPENDIX D

Produced Water Sample Results

\begin{tabular}{|c|c|c|c|c|c|c|c|c|c|c|c|c|c|c|c|c|}
\hline Area & Well & $\begin{array}{c}\text { Sample } \\
\text { Date }\end{array}$ & $\mathrm{pH}$ & TDS & $\mathrm{Ba}$ & $\mathrm{Ca}$ & $\mathrm{Fe}$ & $\mathrm{Mg}$ & $\mathrm{Mn}$ & K & $\mathrm{Na}$ & $\mathrm{Sr}$ & $\mathrm{Cl}$ & $\mathrm{HCO} 3$ & SO4 & LAB \\
\hline Central Taylor & СТ 01 & $1 / 25 / 2013$ & 5.29 & 98,998 & 3,918 & 8,918 & 58 & 966 & 6 & N/A & 25,550 & 1,646 & 58,000 & 30 & 3.2 & Weatherford \\
\hline Central Taylor & СТ 01 & $8 / 4 / 2014$ & 6.00 & 78,381 & 3,169 & 6,786 & 209 & 774 & 6 & 65 & 17,908 & 1,187 & 47,901 & 342 & 0.0 & Baker Hughes \\
\hline Central Taylor & СТ 01 & $9 / 22 / 2015$ & 6.31 & 6,446 & 251 & 541 & 141 & 56 & 4 & 7 & 1,541 & 111 & 3,764 & 37 & 0.0 & NALCO \\
\hline Central Taylor & СТ 01 & $8 / 27 / 2020$ & 7.07 & 1,950 & 82 & 147 & 311 & 15 & 3 & 0 & 194 & 32 & 709 & 17 & $<3.15$ & NRCCE \\
\hline Central Taylor & СТ 02 & $1 / 24 / 2013$ & 4.67 & 58,062 & 2,791 & 4,431 & 71 & 514 & 4 & N/A & 17,760 & 1,336 & 33,400 & 0 & 8.9 & Weatherford \\
\hline Central Taylor & СТ 02 & $3 / 27 / 2013$ & 6.40 & 88,913 & 3,640 & 7,040 & 315 & 4,197 & 2 & 0 & 17,328 & 441 & 55,706 & 244 & 0.1 & XCHEM \\
\hline Central Taylor & СТ 02 & $7 / 24 / 2014$ & 5.20 & 113,793 & 3,142 & 8,855 & 312 & 1,031 & 6 & 188 & 26,917 & 1,933 & 71,155 & 189 & 0.0 & Baker Hughes \\
\hline Central Taylor & СТ 02 & $9 / 22 / 2015$ & 5.56 & 96,377 & 4,759 & 7,257 & 293 & 809 & 7 & 168 & 23,040 & 2,099 & 58,052 & 61 & 0.0 & NALCO \\
\hline Central Taylor & СТ 02 & $8 / 27 / 2020$ & 6.21 & 36,300 & 1,099 & 2,501 & 470 & 233 & 85 & 66 & 7,566 & 646 & 23,021 & 956 & $<3.15$ & NRCCE \\
\hline Central Taylor & СТ 03 & $1 / 25 / 2013$ & 4.72 & 93,627 & 4,048 & 6,607 & 95 & 750 & 8 & N/A & 19,890 & 1,532 & 54,400 & 12 & 25.6 & Weatherford \\
\hline Central Taylor & СТ 03 & $3 / 27 / 2013$ & 6.33 & 93,710 & 3,859 & 7,360 & 251 & 2,245 & 1 & 0 & 21,624 & 376 & 57,775 & 219 & 0.1 & XCHEM \\
\hline Central Taylor & СТ 03 & $7 / 24 / 2014$ & 5.70 & 75,675 & 3,163 & 5,968 & 254 & 714 & 5 & 95 & 17,722 & 1,320 & 46,147 & 248 & 0.0 & Baker Hughes \\
\hline Central Taylor & СТ 03 & $8 / 27 / 2020$ & 6.18 & 3,420 & 67 & 193 & 634 & 15 & 6 & 2 & 355 & 42 & 1,161 & 1,096 & $<3.15$ & NRCCE \\
\hline Central Taylor & СТ 04 & $1 / 23 / 2013$ & 5.54 & 65,715 & 2,937 & 5,455 & 130 & 614 & 5 & N/A & 21,300 & 1,083 & 38,200 & 50 & 24.9 & Weatherford \\
\hline Central Taylor & СТ 04 & $3 / 27 / 2013$ & 6.38 & 114,375 & 4,889 & 11,360 & 294 & 3,318 & 1 & 0 & 22,765 & 414 & 71,114 & 219 & 0.1 & XCHEM \\
\hline Central Taylor & СТ 04 & $7 / 24 / 2014$ & 5.60 & 85,141 & 3,166 & 7,023 & 244 & 818 & 5 & 92 & 19,583 & 1,411 & 52,514 & 244 & 0.0 & Baker Hughes \\
\hline Central Taylor & СТ 04 & $9 / 22 / 2015$ & 5.89 & 50,576 & 2,293 & 3,815 & 117 & 429 & 4 & 75 & 12,470 & 1,021 & 58,052 & 61 & 0.0 & NALCO \\
\hline Central Taylor & СТ 04 & $8 / 27 / 2020$ & 5.53 & 43,340 & 1,760 & 3,069 & 2,012 & 270 & 17 & 79 & 12,815 & 789 & 26,991 & 3,620 & $<3.15$ & NRCCE \\
\hline Central Taylor & СТ 05 & $1 / 24 / 2013$ & 4.85 & 151,090 & 6,180 & 11,380 & 209 & 1,461 & 11 & N/A & 36,660 & 2,189 & 88,400 & 0 & 28.5 & Weatherford \\
\hline Central Taylor & СТ 05 & $3 / 27 / 2013$ & 6.30 & 160,485 & 5,915 & 17,760 & 319 & 3,611 & 2 & 0 & 33,831 & 405 & 98,375 & 268 & 0.2 & XCHEM \\
\hline Central Taylor & СТ 05 & $8 / 4 / 2014$ & 5.70 & 142,578 & 3,137 & 12,350 & 210 & 1,390 & 7 & 148 & 31,959 & 2,582 & 90,629 & 98 & 0.0 & Baker Hughes \\
\hline Central Taylor & СТ 05 & $9 / 22 / 2015$ & 6.01 & 91,832 & 3,882 & 9,468 & 183 & 882 & 6 & 123 & 21,410 & 2,133 & 53,771 & 98 & 0.0 & NALCO \\
\hline Central Taylor & СТ 05 & $8 / 27 / 2020$ & 5.46 & 18,680 & 570 & 1,638 & 381 & 165 & 56 & 28 & 5,524 & 368 & 12,916 & 2,473 & $<3.15$ & NRCCE \\
\hline Central Taylor & СТ 06 & $1 / 24 / 2013$ & 4.85 & 154,246 & 5,505 & 11,100 & 108 & 1,523 & 8 & N/A & 36,560 & 3,095 & 90,200 & 0 & 9.7 & Weatherford \\
\hline Central Taylor & СТ 06 & $3 / 27 / 2013$ & 6.39 & 173,697 & 8,101 & 19,040 & 265 & 878 & 1 & 0 & 40,459 & 456 & 104,301 & 195 & 0.1 & XCHEM \\
\hline Central Taylor & СТ 06 & $7 / 24 / 2014$ & 5.50 & 130,717 & 3,141 & 11,350 & 227 & 1,264 & 6 & 146 & 29,228 & 2,290 & 82,856 & 146 & 0.0 & Baker Hughes \\
\hline Central Taylor & СТ 06 & $9 / 22 / 2015$ & 6.09 & 147,415 & 6,652 & 7,200 & 116 & 1,423 & 8 & 231 & 36,560 & 3,484 & 91,936 & 61 & 0.0 & NALCO \\
\hline Central Taylor & СТ 06 & $8 / 27 / 2020$ & 4.86 & 132,340 & 5,438 & 9,718 & 488 & 990 & 9 & 290 & 37,198 & 3,173 & 85,565 & 916 & $<3.15$ & NRCCE \\
\hline Central Taylor & СТ 07 & $1 / 24 / 2013$ & 5.14 & 155,211 & 3,669 & 11,870 & 154 & 1,556 & 13 & N/A & 37,200 & 3,665 & 91,600 & 16 & 56.9 & Weatherford \\
\hline Central Taylor & СТ 07 & $3 / 27 / 2013$ & 6.41 & 175,136 & 10,535 & 19,680 & 215 & 3,221 & 1 & 0 & 35,352 & 451 & 105,486 & 195 & 0.1 & XCHEM \\
\hline Central Taylor & СТ 07 & $8 / 4 / 2014$ & 5.90 & 132,927 & 3,140 & 11,455 & 182 & 1,265 & 7 & 137 & 29,583 & 2,442 & 84,315 & 342 & 0.0 & Baker Hughes \\
\hline
\end{tabular}




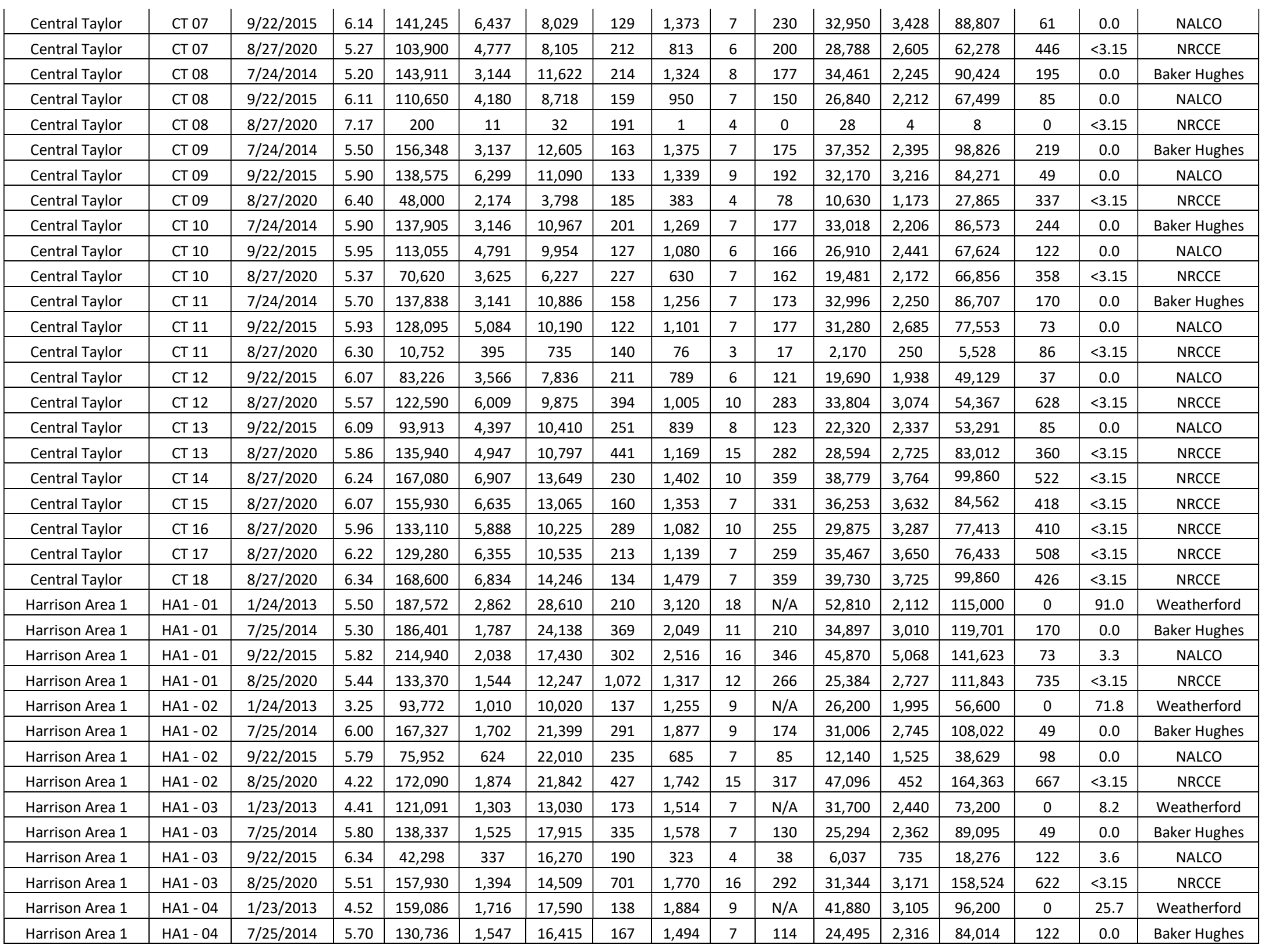




\begin{tabular}{|c|c|c|c|c|c|c|c|c|c|c|c|c|c|c|c|c|}
\hline Harrison Area 1 & HA1 - 04 & $8 / 25 / 2020$ & 5.61 & 126,970 & 1,226 & 11,915 & 223 & 1,237 & 12 & 199 & 26,793 & 2,698 & 136,998 & 381 & $<3.15$ & NRCCE \\
\hline Harrison Area 1 & HA1 - 05 & $1 / 23 / 2013$ & 5.46 & 184,939 & 1,850 & 20,125 & 115 & 1,894 & 9 & N/A & 34,280 & 3,215 & 112,000 & 0 & 0.0 & Weatherford \\
\hline Harrison Area 1 & HA1 - 05 & $7 / 25 / 2014$ & 5.80 & 165,482 & 1,886 & 20,247 & 372 & 1,887 & 9 & 137 & 31,472 & 2,805 & 106,510 & 98 & 0.0 & Baker Hughes \\
\hline Harrison Area 1 & HA1 - 05 & $9 / 22 / 2015$ & 6.23 & 114,078 & 1,359 & 3,586 & 215 & 1,431 & 8 & 143 & 27,040 & 3,002 & 77,365 & 73 & 0.0 & NALCO \\
\hline Harrison Area 1 & HA1 - 05 & $8 / 25 / 2020$ & 5.39 & 110,540 & 1,041 & 10,191 & 248 & 1,078 & 9 & 164 & 23,075 & 2,298 & 92,654 & 444 & $<3.15$ & NRCCE \\
\hline Harrison Area 1 & HA1 - 06 & $7 / 25 / 2014$ & 5.60 & 221,392 & 3,177 & 25,814 & 138 & 2,332 & 10 & 241 & 42,515 & 3,424 & 143,413 & 244 & 0.0 & Baker Hughes \\
\hline Harrison Area 1 & HA1 - 06 & $9 / 22 / 2015$ & 5.91 & 199,220 & 3,931 & 21,580 & 139 & 2,230 & 13 & 269 & 43,740 & 4,400 & 123,090 & 98 & 0.0 & NALCO \\
\hline Harrison Area 1 & HA1 - 06 & $8 / 6 / 2020$ & 5.62 & 218,890 & 4,287 & 24,887 & 166 & 2,042 & 14 & 412 & 46,136 & 4,832 & 138,248 & 424 & $<3.15$ & NRCCE \\
\hline Harrison Area 1 & HA1 - 07 & $9 / 22 / 2015$ & 5.85 & 202,534 & 4,021 & 21,080 & 148 & 2,244 & 13 & 265 & 43,200 & 4,375 & 127,328 & 122 & 3.2 & NALCO \\
\hline Harrison Area 1 & HA1 - 07 & $8 / 6 / 2020$ & 5.25 & 229,940 & 4,407 & 25,735 & 159 & 2,082 & 14 & 424 & 47,431 & 4,867 & 224,112 & 326 & $<3.15$ & NRCCE \\
\hline Harrison Area 1 & HA1 - 08 & $7 / 25 / 2014$ & 5.30 & 220,177 & 3,171 & 25,568 & 158 & 2,298 & 10 & 236 & 43,667 & 3,440 & 141,523 & 24 & 0.0 & Baker Hughes \\
\hline Harrison Area 1 & HA1 - 08 & $9 / 22 / 2015$ & 5.57 & 199,432 & 4,234 & 22,660 & 141 & 2,178 & 13 & 264 & 40,950 & 4,206 & 124,929 & 122 & 0.0 & NALCO \\
\hline Harrison Area 1 & HA1 - 08 & $8 / 6 / 2020$ & 5.54 & 212,850 & 4,404 & 23,717 & 159 & 1,882 & 12 & 393 & 45,260 & 4,702 & 201,423 & 386 & $<3.15$ & NRCCE \\
\hline Harrison Area 1 & HA1 - 09 & $7 / 25 / 2014$ & 5.60 & 209,423 & 3,179 & 23,950 & 158 & 2,205 & 18 & 238 & 41,699 & 3,195 & 134,600 & 98 & 0.0 & Baker Hughes \\
\hline Harrison Area 1 & HA1 - 09 & $9 / 22 / 2015$ & 5.75 & 185,111 & 3,739 & 11,510 & 222 & 2,107 & 20 & 256 & 42,030 & 4,145 & 121,191 & 147 & 0.0 & NALCO \\
\hline Harrison Area 1 & HA1 - 10 & $7 / 25 / 2014$ & 5.20 & 182,661 & 2,180 & 21,238 & 163 & 2,055 & 10 & 197 & 36,101 & 2,908 & 117,615 & 98 & 0.0 & Baker Hughes \\
\hline Harrison Area 1 & HA1 - 10 & $9 / 22 / 2015$ & 6.12 & 158,360 & 1,749 & 27,640 & 145 & 1,607 & 10 & 179 & 32,860 & 3,216 & 91,036 & 98 & 0.0 & NALCO \\
\hline Harrison Area 1 & $\mathrm{HA} 1-10$ & $8 / 18 / 2020$ & 5.32 & 137,160 & 1,842 & 17,082 & 167 & 1,355 & 9 & 249 & 31,355 & 3,674 & 95,156 & 348 & $<3.15$ & NRCCE \\
\hline Harrison Area 1 & HA1 - 11 & $7 / 25 / 2014$ & 5.60 & 197,421 & 2,264 & 23,792 & 148 & 2,233 & 11 & 166 & 38,099 & 3,180 & 127,379 & 73 & 50.0 & Baker Hughes \\
\hline Harrison Area 1 & HA1 - 11 & $9 / 22 / 2015$ & 6.18 & 145,084 & 1,757 & 7,723 & 179 & 1,783 & 11 & 170 & 30,910 & 3,663 & 98,982 & 73 & 3.9 & NALCO \\
\hline Harrison Area 1 & HA1 - 11 & $8 / 18 / 2020$ & 5.42 & 154,590 & 1,619 & 17,570 & 171 & 1,540 & 9 & 240 & 33,136 & 3,494 & 99,161 & 351 & $<3.15$ & NRCCE \\
\hline Harrison Area 1 & HA1 - 12 & $7 / 25 / 2014$ & 5.10 & 184,443 & 2,198 & 22,065 & 166 & 2,067 & 11 & 153 & 35,837 & 2,947 & 118,817 & 110 & 0.0 & Baker Hughes \\
\hline Harrison Area 1 & HA1 - 12 & $9 / 22 / 2015$ & 6.26 & 146,203 & 1,723 & 14,850 & 169 & 1,431 & 11 & 143 & 30,860 & 3,435 & 93,388 & 98 & 0.0 & NALCO \\
\hline Harrison Area 1 & HA1 - 12 & $8 / 18 / 2020$ & 5.42 & 205,700 & 2,770 & 26,930 & 389 & 2,054 & 14 & 341 & 46,502 & 5,504 & 124,102 & 492 & $<3.15$ & NRCCE \\
\hline Harrison Area 1 & HA1 - 13 & $8 / 18 / 2020$ & 5.48 & 146,870 & 1,980 & 16,824 & 167 & 1,477 & 9 & 231 & 31,682 & 3,384 & 95,332 & 399 & $<3.15$ & NRCCE \\
\hline Harrison Area 1 & HA1 - 14 & $8 / 18 / 2020$ & 5.43 & 165,640 & 2,262 & 18,395 & 188 & 1,583 & 10 & 255 & 34,394 & 3,918 & 98,784 & 461 & $<3.15$ & NRCCE \\
\hline Harrison Area 1 & HA1 - 15 & $8 / 18 / 2020$ & 5.24 & 130,460 & 1,536 & 15,600 & 235 & 1,379 & 8 & 194 & 27,877 & 3,484 & 84,681 & 452 & $<3.15$ & NRCCE \\
\hline Harrison Area 1 & HA1 - 16 & $8 / 18 / 2020$ & 5.13 & 137,540 & 1,545 & 16,532 & 192 & 1,449 & 9 & 210 & 29,935 & 3,628 & 86,445 & 423 & $<3.15$ & NRCCE \\
\hline Harrison Area 1 & HA1 - 17 & $8 / 18 / 2020$ & 5.75 & 194,860 & 1,941 & 23,370 & 192 & 2,050 & 10 & 351 & 40,961 & 4,678 & 113,081 & 423 & $<3.15$ & NRCCE \\
\hline Harrison Area 1 & HA1 - 18 & $8 / 18 / 2020$ & 5.46 & 200,550 & 1,969 & 22,350 & 195 & 1,956 & 10 & 296 & 40,675 & 4,528 & 112,225 & 416 & $<3.15$ & NRCCE \\
\hline Harrison Area 2 & $\mathrm{HA} 2-01$ & $1 / 24 / 2013$ & 5.25 & 167,520 & 2,567 & 15,860 & 49 & 1,999 & 9 & N/A & 39,640 & 1,605 & 101,600 & 40 & 6.2 & Weatherford \\
\hline Harrison Area 2 & $\mathrm{HA} 2-01$ & $3 / 28 / 2013$ & 6.21 & 196,620 & 3,115 & 22,880 & 253 & 6,637 & 1 & 0 & 39,318 & 412 & 123,857 & 146 & 0.4 & XCHEM \\
\hline Harrison Area 2 & $\mathrm{HA} 2-01$ & $7 / 24 / 2014$ & 6.50 & 195,390 & 3,145 & 22,200 & 221 & 2,064 & 9 & 191 & 39,837 & 3,110 & 124,503 & 48 & 0.0 & Baker Hughes \\
\hline
\end{tabular}




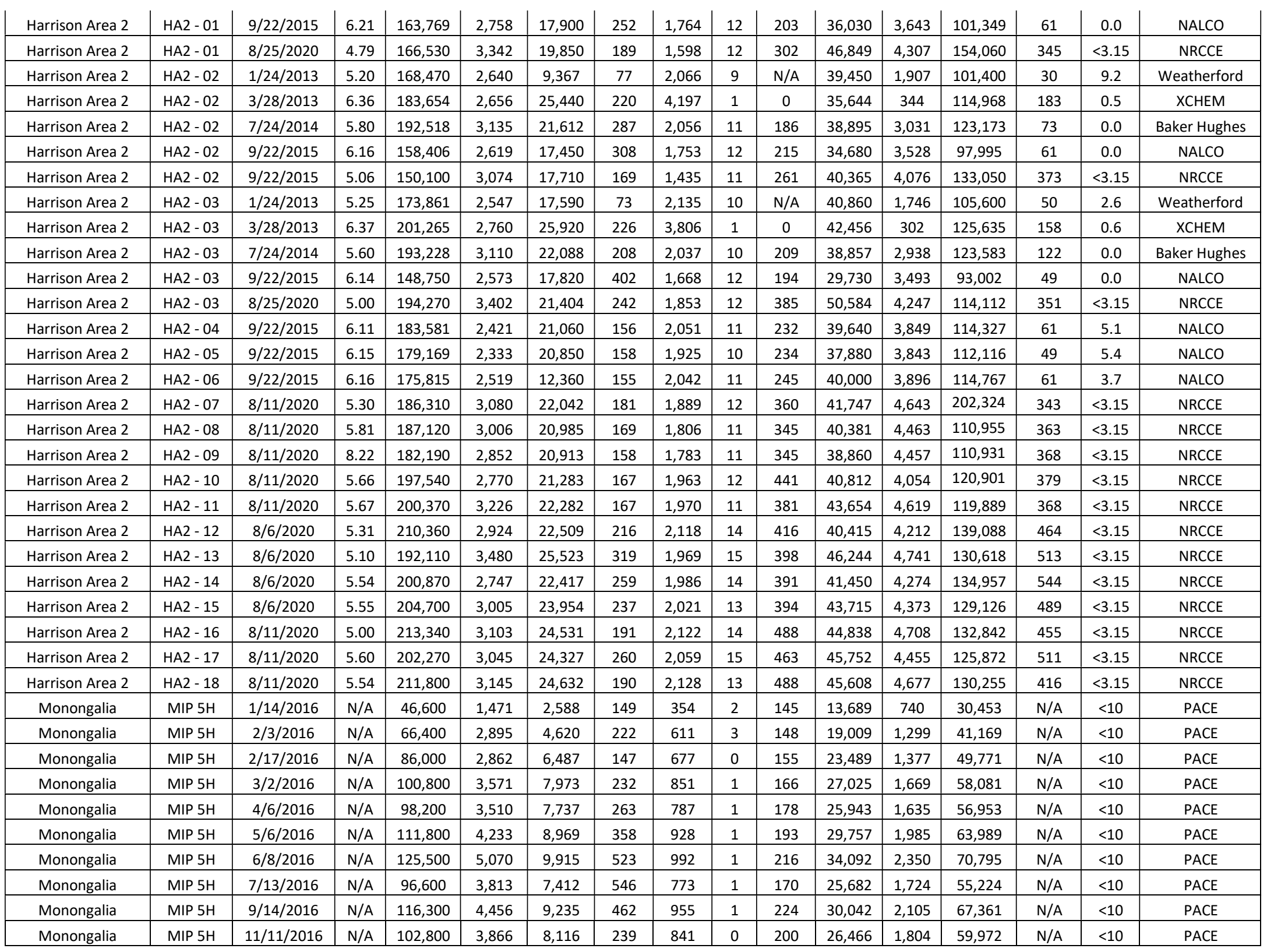




\begin{tabular}{|c|c|c|c|c|c|c|c|c|c|c|c|c|c|c|c|c|}
\hline Monongalia & MIP 5H & $3 / 15 / 2017$ & $\mathrm{~N} / \mathrm{A}$ & 248,200 & 10,375 & 22,736 & 541 & 2,059 & 1 & 610 & 63,039 & 4,912 & 140,866 & $\mathrm{~N} / \mathrm{A}$ & $<10$ & PACE \\
\hline Monongalia & MIP 5H & $8 / 26 / 2020$ & 5.47 & 82,200 & 4,528 & 7,043 & 273 & 707 & 5 & 106 & 22,800 & 1,893 & 48,332 & 259 & $<3.15$ & NRCCE \\
\hline Monongalia & MIP $3 \mathrm{H}$ & $1 / 14 / 2016$ & $\mathrm{~N} / \mathrm{A}$ & 75,400 & 2,650 & 6,759 & 118 & 740 & 11 & 138 & 19,939 & 1,402 & 47,731 & $\mathrm{~N} / \mathrm{A}$ & $<10$ & PACE \\
\hline Monongalia & MIP $3 \mathrm{H}$ & $2 / 3 / 2016$ & $\mathrm{~N} / \mathrm{A}$ & 92,900 & 3,504 & 8,225 & 173 & 904 & 14 & 148 & 22,939 & 1,759 & 59,649 & $\mathrm{~N} / \mathrm{A}$ & $<10$ & PACE \\
\hline Monongalia & MIP 3H & $2 / 17 / 2016$ & $\mathrm{~N} / \mathrm{A}$ & 110,700 & 3,862 & 9,987 & 175 & 1,033 & 1 & 160 & 27,632 & 1,867 & 64,685 & N/A & $<10$ & PACE \\
\hline Monongalia & MIP 3H & $4 / 6 / 2016$ & N/A & 118,200 & 4,310 & 10,674 & 237 & 1,130 & 1 & 187 & 29,871 & 2,083 & 68,220 & N/A & $<10$ & PACE \\
\hline Monongalia & MIP 3H & $5 / 6 / 2016$ & N/A & 129,300 & 4,919 & 11,843 & 353 & 1,206 & 2 & 189 & 32,465 & 2,317 & 74,338 & N/A & $<10$ & PACE \\
\hline Monongalia & MIP $3 \mathrm{H}$ & $6 / 8 / 2016$ & $\mathrm{~N} / \mathrm{A}$ & 107,400 & 4,137 & 9,323 & 600 & 907 & 1 & 160 & 27,038 & 1,962 & 61,917 & $\mathrm{~N} / \mathrm{A}$ & $<10$ & PACE \\
\hline Monongalia & MIP $3 \mathrm{H}$ & $9 / 14 / 2016$ & $\mathrm{~N} / \mathrm{A}$ & 119,100 & 4,541 & 10,575 & 484 & 1,047 & 1 & 190 & 29,605 & 2,189 & 68,952 & $\mathrm{~N} / \mathrm{A}$ & $<10$ & PACE \\
\hline Monongalia & MIP 3H & $1 / 18 / 2017$ & $\mathrm{~N} / \mathrm{A}$ & 153,000 & 6,836 & 13,930 & 181 & 1,354 & 1 & 174 & 38,873 & 3,098 & 86,469 & N/A & $<10$ & PACE \\
\hline Monongalia & MIP 3H & $3 / 15 / 2017$ & $\mathrm{~N} / \mathrm{A}$ & 145,400 & 5,698 & 14,052 & 163 & 1,269 & 1 & 214 & 36,265 & 2,952 & 82,990 & $\mathrm{~N} / \mathrm{A}$ & $<10$ & PACE \\
\hline Monongalia & MIP 3H & $4 / 12 / 2017$ & $\mathrm{~N} / \mathrm{A}$ & 157,700 & 6,656 & 15,195 & 223 & 1,384 & 1 & 213 & 39,321 & 3,083 & 89,573 & N/A & $<10$ & PACE \\
\hline Monongalia & MIP 3H & $8 / 26 / 2020$ & 5.80 & 19,110 & 847 & 1,617 & 82 & 160 & 3 & 20 & 4,763 & 398 & 10,913 & 54 & $<3.15$ & NRCCE \\
\hline Northeast Taylor & NET - 01 & $7 / 24 / 2014$ & 8.30 & 157,524 & 3,123 & 12,236 & 214 & 1,354 & 8 & 158 & 38,051 & 2,488 & 99,546 & 268 & 0.0 & Baker Hughes \\
\hline Northeast Taylor & NET - 01 & $9 / 22 / 2015$ & 6.21 & 65,296 & 2,155 & 3,250 & 82 & 361 & 2 & 128 & 17,300 & 898 & 41,146 & 98 & 3.9 & NALCO \\
\hline Northeast Taylor & NET - 01 & $10 / 18 / 2018$ & 6.68 & 95,291 & 4,422 & 6,359 & 236 & 642 & 6 & N/A & 30,579 & 1,747 & 50,860 & 440 & $<0.25$ & NALCO \\
\hline Northeast Taylor & NET - 01 & $8 / 6 / 2020$ & 5.70 & 60,480 & 3,608 & 4,732 & 204 & 468 & 4 & 88 & 15,064 & 1,407 & 42,146 & 172 & $<3.15$ & NRCCE \\
\hline Northeast Taylor & NET - 02 & $7 / 24 / 2014$ & 5.80 & 151,760 & 3,126 & 11,689 & 203 & 1,287 & 7 & 155 & 36,289 & 2,326 & 96,333 & 268 & 0.0 & Baker Hughes \\
\hline Northeast Taylor & NET - 02 & $9 / 22 / 2015$ & 6.18 & 82,368 & 4,205 & 5,680 & 117 & 597 & 5 & 101 & 17,310 & 1,496 & 52,873 & 85 & 1.0 & NALCO \\
\hline Northeast Taylor & NET - 02 & $8 / 2 / 2018$ & 6.73 & 94,542 & 5,582 & 8,317 & 153 & 831 & 5 & $\mathrm{~N} / \mathrm{A}$ & 24,096 & 2,063 & 53,190 & 305 & $<0.25$ & NALCO \\
\hline Northeast Taylor & NET - 02 & $10 / 18 / 2018$ & 6.60 & 107,350 & 5,889 & 8,714 & 164 & 881 & 5 & N/A & 19,920 & 2,337 & 69,000 & 440 & $<0.25$ & NALCO \\
\hline Northeast Taylor & NET - 02 & $8 / 6 / 2020$ & 5.73 & 66,510 & 3,686 & 4,862 & 206 & 481 & 4 & 95 & 15,606 & 1,446 & 42,612 & 285 & $<3.15$ & NRCCE \\
\hline Northeast Taylor & NET - 03 & $9 / 22 / 2015$ & 5.94 & 149,473 & 7,173 & 19,530 & 186 & 1,073 & 7 & 158 & 30,210 & 2,585 & 88,624 & 85 & 0.0 & NALCO \\
\hline Northeast Taylor & NET - 03 & $8 / 2 / 2018$ & 6.88 & 45,526 & 2,752 & 3,812 & 156 & 391 & 3 & N/A & 11,849 & 1,032 & 25,287 & 244 & $<0.25$ & NALCO \\
\hline Northeast Taylor & NET - 03 & $10 / 18 / 2018$ & 6.58 & 53,953 & 1,975 & 2,692 & 128 & 274 & 3 & N/A & 26,125 & 765 & 21,640 & 352 & $<0.25$ & NALCO \\
\hline Northeast Taylor & NET - 03 & $8 / 6 / 2020$ & 6.12 & 19,140 & 943 & 1,260 & 101 & 124 & 2 & 23 & 3,910 & 398 & 12,621 & 43 & $<3.15$ & NRCCE \\
\hline Northeast Taylor & NET - 04 & $8 / 2 / 2018$ & 6.71 & 113,425 & 4,705 & 9,768 & 145 & 1,008 & 4 & N/A & 30,222 & 1,866 & 65,524 & 183 & $<0.25$ & NALCO \\
\hline Northeast Taylor & NET - 04 & $10 / 18 / 2018$ & 6.62 & 125,007 & 4,491 & 9,313 & 152 & 977 & 4 & N/A & 32,369 & 1,955 & 75,262 & 484 & $<0.25$ & NALCO \\
\hline Northeast Taylor & NET - 04 & $8 / 6 / 2020$ & 1.61 & 112,060 & 5,084 & 8,749 & 181 & 906 & 5 & 173 & 29,927 & 2,143 & 71,815 & 256 & $<3.15$ & NRCCE \\
\hline Northeast Taylor & NET - 05 & $8 / 2 / 2018$ & 6.65 & 118,540 & 5,366 & 9,739 & 175 & 1,092 & 5 & $\mathrm{~N} / \mathrm{A}$ & 32,645 & 2,168 & 67,082 & 268 & $<0.25$ & NALCO \\
\hline Northeast Taylor & NET - 05 & $10 / 18 / 2018$ & 6.51 & 130,951 & 5,142 & 9,649 & 373 & 1,054 & 9 & $\mathrm{~N} / \mathrm{A}$ & 34,078 & 2,298 & 77,798 & 550 & $<0.25$ & NALCO \\
\hline Northeast Taylor & NET - 06 & $10 / 18 / 2018$ & 6.48 & 139,279 & 6,287 & 10,023 & 317 & 1,112 & 7 & N/A & 33,246 & 2,642 & 84,861 & 784 & $<0.25$ & NALCO \\
\hline Northeast Taylor & NET - 06 & $8 / 27 / 2020$ & 6.75 & 78,510 & 4,444 & 5,996 & 175 & 599 & 4 & N/A & 23,815 & 1,664 & 47,113 & 386 & $<3.15$ & NRCCE \\
\hline
\end{tabular}




\begin{tabular}{|c|c|c|c|c|c|c|c|c|c|c|c|c|c|c|c|c|}
\hline Northeast Taylor & NET - 07 & $8 / 2 / 2018$ & 6.67 & 126,010 & 6,374 & 10,010 & 152 & 1,112 & 5 & $\mathrm{~N} / \mathrm{A}$ & 32,254 & 2,336 & 73,512 & 256 & $<0.25$ & NALCO \\
\hline Northeast Taylor & NET - 07 & $10 / 18 / 2018$ & 6.60 & 137,566 & 6,177 & 10,045 & 361 & 1,088 & 10 & $\mathrm{~N} / \mathrm{A}$ & 35,908 & 2,501 & 80,992 & 484 & $<0.25$ & NALCO \\
\hline Northeast Taylor & NET - 07 & $8 / 27 / 2020$ & 6.49 & 95,550 & 5,394 & 7,181 & 151 & 716 & 4 & 146 & 27,388 & 2,015 & 56,341 & 369 & $<3.15$ & NRCCE \\
\hline Northeast Taylor & NET - 08 & $8 / 2 / 2018$ & 6.67 & 127,333 & 6,714 & 9,820 & 126 & 1,130 & 5 & $\mathrm{~N} / \mathrm{A}$ & 33,096 & 2,430 & 73,756 & 256 & $<0.25$ & NALCO \\
\hline Northeast Taylor & NET - 08 & $10 / 18 / 2018$ & 6.76 & 153,027 & 7,150 & 10,690 & 165 & 1,213 & 5 & $\mathrm{~N} / \mathrm{A}$ & 39,765 & 2,791 & 90,741 & 506 & $<0.25$ & NALCO \\
\hline Northeast Taylor & NET - 08 & $8 / 27 / 2020$ & 6.31 & 117,650 & 6,751 & 8,685 & 151 & 884 & 5 & 177 & 32,837 & 2,478 & 67,700 & 410 & $<3.15$ & NRCCE \\
\hline Northeast Taylor & NET - 09 & $8 / 2 / 2018$ & 6.69 & 116,999 & 4,779 & 9,159 & 85 & 991 & 3 & $\mathrm{~N} / \mathrm{A}$ & 31,448 & 1,902 & 68,411 & 220 & $<0.25$ & NALCO \\
\hline Northeast Taylor & NET - 09 & $3 / 27 / 2018$ & 6.71 & 114,599 & 5,407 & 9,953 & 115 & 1,158 & 4 & $\mathrm{~N} / \mathrm{A}$ & 38,636 & 2,307 & 86,811 & 207 & $<0.25$ & NALCO \\
\hline Northeast Taylor & NET - 10 & $10 / 18 / 2018$ & 6.41 & 159,862 & 6,853 & 11,651 & 152 & 1,339 & 5 & $\mathrm{~N} / \mathrm{A}$ & 35,616 & 2,974 & 100,744 & 528 & $<0.25$ & NALCO \\
\hline Northeast Taylor & NET - 10 & $8 / 6 / 2020$ & 5.41 & 171,220 & 6,930 & 11,704 & 124 & 1,320 & 5 & $\mathrm{~N} / \mathrm{A}$ & 35,971 & 2,953 & 96,067 & 382 & $<3.15$ & NRCCE \\
\hline Northeast Taylor & NET - 11 & $8 / 22 / 2018$ & 5.60 & 149,254 & 6,444 & 10,632 & 132 & 1,228 & 4 & $\mathrm{~N} / \mathrm{A}$ & 37,165 & 2,665 & 90,741 & 244 & $<0.25$ & NALCO \\
\hline Northeast Taylor & NET - 11 & $10 / 18 / 2018$ & 6.47 & 150,881 & 6,356 & 10,530 & 141 & 1,215 & 4 & $\mathrm{~N} / \mathrm{A}$ & 36,672 & 2,757 & 92,721 & 484 & $<0.25$ & NALCO \\
\hline Northeast Taylor & NET - 11 & $8 / 6 / 2020$ & 5.16 & 148,400 & 8,464 & 11,298 & 662 & 1,208 & 13 & $\mathrm{~N} / \mathrm{A}$ & 42,328 & 3,440 & 134,373 & 1,039 & $<3.15$ & NRCCE \\
\hline Northeast Taylor & NET - 12 & $8 / 22 / 2018$ & 5.60 & 164,570 & 7,478 & 11,738 & 136 & 1,344 & 5 & $\mathrm{~N} / \mathrm{A}$ & 40,564 & 3,030 & 100,069 & 207 & $<0.25$ & NALCO \\
\hline Northeast Taylor & NET - 12 & $10 / 18 / 2018$ & 6.39 & 162,007 & 7,039 & 11,140 & 141 & 1,278 & 5 & $\mathrm{~N} / \mathrm{A}$ & 40,135 & 2,997 & 98,723 & 550 & $<0.25$ & NALCO \\
\hline Northeast Taylor & NET - 13 & $8 / 22 / 2018$ & 5.40 & 168,433 & 7,705 & 12,017 & 164 & 1,320 & 5 & $\mathrm{~N} / \mathrm{A}$ & 41,874 & 3,031 & 102,097 & 220 & $<0.25$ & NALCO \\
\hline Northeast Taylor & NET - 13 & $10 / 18 / 2018$ & 6.35 & 165,334 & 7,580 & 11,425 & 161 & 1,313 & 5 & $\mathrm{~N} / \mathrm{A}$ & 39,856 & 3,047 & 101,419 & 528 & $<0.25$ & NALCO \\
\hline Northeast Taylor & NET - 13 & $8 / 6 / 2020$ & 4.97 & 182,370 & 9,795 & 15,043 & 740 & 1,392 & 12 & 306 & 49,354 & 4,040 & 109,884 & 1,223 & $<3.15$ & NRCCE \\
\hline Northeast Taylor & NET - 14 & $8 / 22 / 2018$ & 5.50 & 160,843 & 6,891 & 11,340 & 208 & 1,250 & 5 & $\mathrm{~N} / \mathrm{A}$ & 39,339 & 2,903 & 98,723 & 183 & $<0.25$ & NALCO \\
\hline Northeast Taylor & NET - 14 & $10 / 18 / 2018$ & 6.46 & 158,850 & 7,072 & 11,295 & 168 & 1,282 & 5 & $\mathrm{~N} / \mathrm{A}$ & 37,358 & 3,003 & 98,051 & 616 & $<0.25$ & NALCO \\
\hline Northeast Taylor & NET - 14 & $8 / 6 / 2020$ & 5.50 & 151,210 & 7,827 & 11,716 & 193 & 1,236 & 5 & $\mathrm{~N} / \mathrm{A}$ & 38,964 & 3,265 & 95,871 & 345 & $<3.15$ & NRCCE \\
\hline
\end{tabular}

